University of Rhode Island

DigitalCommons@URI

Open Access Master's Theses

2015

\title{
A War at the Heart of Man: The Structure and Construction of Ships Bound for Africa
}

Jessica A. Glickman

University of Rhode Island, jessicaglickman@aol.com

Follow this and additional works at: https://digitalcommons.uri.edu/theses

\section{Recommended Citation}

Glickman, Jessica A., "A War at the Heart of Man: The Structure and Construction of Ships Bound for Africa" (2015). Open Access Master's Theses. Paper 666.

https://digitalcommons.uri.edu/theses/666

This Thesis is brought to you for free and open access by DigitalCommons@URI. It has been accepted for inclusion in Open Access Master's Theses by an authorized administrator of DigitalCommons@URI. For more information, please contact digitalcommons-group@uri.edu. 
A WAR AT THE HEART OF MAN:

THE STRUCTURE AND CONSTRUCTION OF SHIPS

BOUND FOR AFRICA

BY

JESSICA A. GLICKMAN

A THESIS SUBMITTED IN PARTIAL FULFILLMENT OF THE

REQUIREMENTS FOR THE DEGREE OF

MASTERS OF ARTS

IN

HISTORY

UNIVERSITY OF RHODE ISLAND

2015 
MASTER OF ARTS IN HISTORY THESIS

$\mathrm{OF}$

JESSICA A. GLICKMAN

\section{APPROVED:}

Thesis Committee:

$\begin{array}{cc}\text { Major Professor } & \text { Rod Mather } \\ \text { John Jensen } \\ \text { Kristine Bovy } \\ \text { Nasser H. Zawia } \\ \text { DEAN OF THE GRADUATE SCHOOL }\end{array}$

UNIVERSITY OF RHODE ISLAND

2015 


\begin{abstract}
Since the abolition of the international slave trade in 1807 , and even before, scholars and activists have focused on the conditions Africans experienced during the Middle Passage. ${ }^{1}$ Surprisingly, little attention has been paid to the ships that carried the captives. This study will examine the historical and archaeological evidence of the vessels involved in the slave trade. It will address their form and function; and why and how they were built? It will also address the question of design-dedicated slave ships and the issue of whether or not some slave ships were built specially for the trade. This study will look at the historical and archaeological implications of viewing slave ships as purpose-built entities that have a unique place in the archaeological record. As such, it challenges the commonly held perception that slave ships where sent haphazardly to Africa without regard for profit or the maintenance of their human cargoes. $^{2}$
\end{abstract}

\footnotetext{
${ }^{1}$ Jay Coughtry, The Notorious Triangle; Rhode Island and the African Slave Trade 1700-1807 (Philadelphia: Temple Univ. Press, 1981), 12.

${ }^{2}$ Simon Hogerzeil and David Richardson, "Slavery Purchasing Strategies and Shipboard Mortality: Day-to-Day Evidence from the Dutch Africa trade, 1751-1797," The Journal of Economic History 67:1(2007): 160-190.
} 


\section{ACKNOWLEDGMENTS}

First I would like to acknowledge my advisor Dr. Rod Mather, who has acted as an advisor, mentor and friend. Dr. Mather's guidance has been instrumental in my success as a graduate student and his encouragement has inspired me. I would also like to acknowledge the rest of my committee, Dr. John Jensen and Dr. Kristine Bovy, for their help and support, and Dr. Cheryl Foster for sweeping in to save the day. I would also like to Acknowledge Anya Hanson, who has taught me that woman in diving can have it all. Finally I would like to acknowledge my husband, Sean Irwin, for his support and never allowing me to give up no matter how complicated life gets. 


\section{TABLE OF CONTENTS}

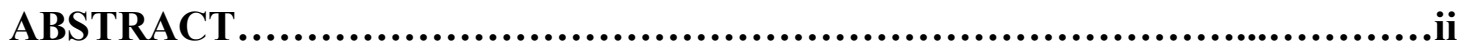

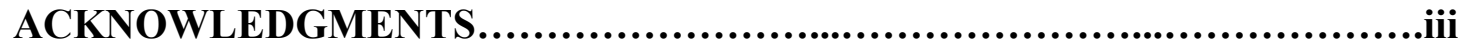

TABLE OF CONTENTS.......................................................iv

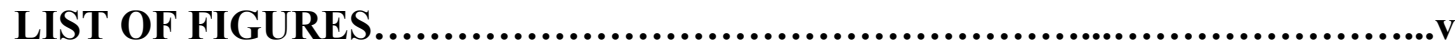

CHAPTER 1 ............................................................................1

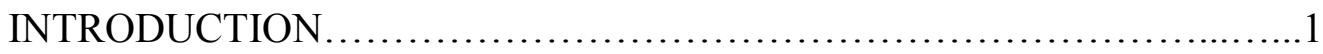

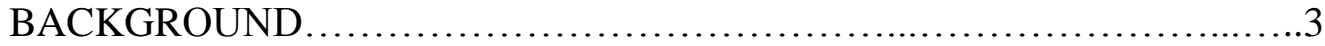

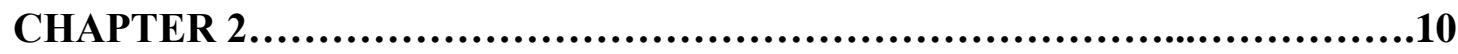

HISTORIOGRAPHY OF SLAVE SHIPS AND THE SLAVE TRADE......10

CHATER 3............................................................................21

ARCHAEOLOGICAL INVESTIGATION OF SLAVE SHIPS..............21

CHAPTER 4.......................................................................56

MATERIAL CULTURE...........................................56

CHAPTER 5...................................................................73

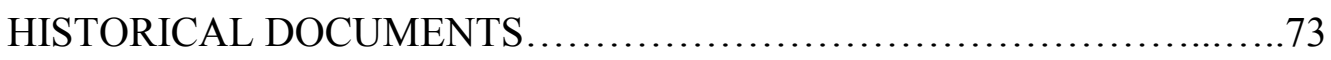

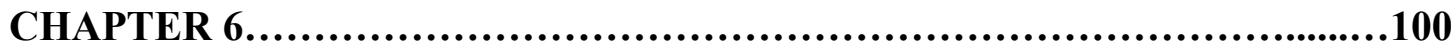

EXAMIN THE ART............................................ 100

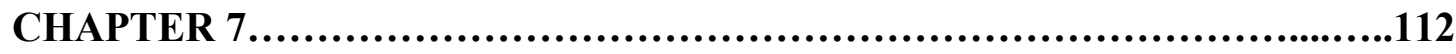

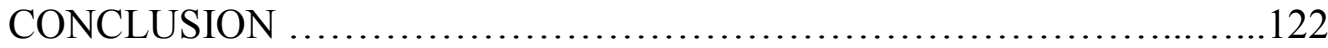

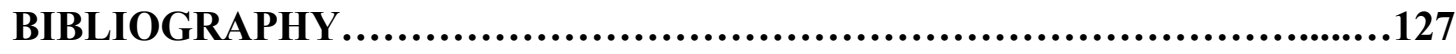




\section{LIST OF FIGURES}

FIGURE

PAGE

Figure 1.1. Malcolm P.R. Light. The giant equatorial current gyres in the Southern and Northern Hemisphere. 2010, Image, Arctic New. http://arctic-

news.blogspot.com/2014/01/global-warming-and-the-gulf-stream.html...

Figure 2.1. William Alfred. Stowage of the British Slave Ship 'Brookes' under the Regulated Slave Trade, Act of 1788. 1790, Lithograph, Broadside Collection, Rare Books and Special Collections Division, Library of Congress.................... 14

Figure 2.2. Committee of the Religious Society of Friends in London. Case of the Vigilante, a ship employed in the slave trade; with some reflections on that traffic. 1823, Boston Public Library. .................................................15

Figure 2.3. Robert LL.D. Walsh. Notices of Brazil in 1828 and 1829. 1829, Print, British Library, Historical Prints Editions

Figure 3.1. Georg Braun Franz Hogenberg, and John Goss. Elmina, Print, in The City Maps of Europe: $16^{\text {th }}$ Century town Plans from Braun \& Hogenberg (Chicago: Rand

McNally, 1992)................................................................28

Figure 3.2. Frederik Chapman, Common Vessel Types of the $18^{\text {th }}$ Century, 2006, Line drawing, in Frederik Chapman, Architectura Navalis Mercatoria: The Classic of Eighteenth-Century Naval Architecture (New York: Dover Publications, Inc.), Plate LXII............................................................... 32

Figure 3.3. The Henrietta Marie, 1997, Line Drawing, in David Moore, "Site Report: Historical and Archaeological Investigation of the Shipwreck Henrietta Marie." (Mel Fisher Maritime Heritage Society, 1997)....................................... 36

Figure 3.4. The Slave Ship Whydah, 2009. Line Drawing, https://www.nauticus.org/pirates/slaveship.html

Figure 3.5. Joseph Nicholls, Captain Teach commonly call'd Blackbeard. 1736, engraving. $28.3 \mathrm{~cm} \times 19.4$, in Captain Charles Johnson. A General History of the lives and adventures of the most famous highwaymen, murders, street-robbers, and captains. (Horace's head: London, 1736), 202. Housed in the John Carter Brown Library at Brown University....

Figure 3.6. Jean Bellis, The Rear of the Slave Ship Aurora, Monograph, reproduced from Jean Boudriot, Monographie De L'Aurore- Navire negrier-1784 (Nice, France :Ancre) 95.

http://www.histoiremaritimebretagnenord.fr/activit\%C3\%A9s-maritimes/la-guerre- 
en-mer/

Figure 3.7: The anchorage off the Town of Bonny River sixteen miles from the Entrance, water color with graphite, $200 \mathrm{~mm}$ x 370mm, national Maritime Museum, Greenwich London, http://collections.rmg.co.uk/collections/objects/106080.html.....48

Figure 3.8. The Illustrated London News, Section of the Slaver "Abbot Devereux", 1857, Line Drawing, in The Illustrated London News 31(1857),

284http://hitchcock.itc.virginia.edu/Slavery/details.php?categorynum=5\&categoryNa

me $=\&$ the Record $=40 \&$ recordCount $=78$.

Figure 4.1. National Museum of Bermuda, Instagram post, September 8, 2014, http://instagram.com/p/sr2Qfshxbb/?modal=true

Figure 4.2. North Museum Service Centre, Lead bale seal from Salem Maritime National Historic site, 2012, photograph, Salem Maritime National Historic Site Collection, Salem Ma. https://nmscarcheologylab.wordpress.com/page/4/ .... .62

Figure 4.3. Iziko Museums, Iron bars. Picture, 2015, accessed June 15, 2015 http://www.smithsonianmag.com/smithsonian-institution/sunken-18th-century-slaveship-found-south-africa-180955458/?n.

Figure 4.4. Figure 4.4: Eugenia Herbert, Manillas: Full Size, ink drawing, in Red Gold of Africa: Copper in Precolonial History and Culture. (Madison: University of Wisconsin Press, 1984), 204................................................64

Figure 4.5. Corey Malcom, Glass 'seed' beads, 2001, photograph, in Corey Malcom "A Collection of Artifacts Recovered from the Shipwreck Henrietta Marie, 2002." Mel Fisher Maritime Heritage Society, Key West, 2002. .66

Figure 4.6. Jessica Glickman, Beads at the Liverpool Museum, Photograph, 2013, personal collection of photographs.

Figure 4.7. Jean Bourdriot, Leg and Wrist Shackles used on Slave Ship, 1784, Line Drawing, in Jean Boudriot, Traite et Navire Negrier l'Aurore, 1784, (Paris, Published by author 1984), 84 .

http://hitchcock.itc.virginia.edu/Slavery/details.php? categorynum=5\&categoryName= $\&$ theRecord $=34 \&$ recordCount $=71$.

Figure 4.8. Frank Besse, Shackles on Slave ship Henrietta Marie, 1997, line drawing, in David Moore, "Site Report: Historical and Archaeological Investigation of the Shipwreck Henrietta Marie.” (Mel Fisher Maritime Heritage Society, 1997). http://hitchcock.itc. virginia.edu/Slavery/details.php?categorynum=5\&categoryName= \& theRecord=27\&recordCount $=78$.

Figure 5.1. Carole Bos. "The Triangle Trade," 2007, digital image, Amazing Stories, accessed January 2, 2015, https://www.awesomestories.com/asset/view/THETRIANGLE-TRADE-Amazing. 
Figure 5.2. A Cross-Section of the Slave Ship the Henrietta Marie. 1995, Line Drawing, in Bill Muir \& Frank Besse, A Slave ship Speaks: The Wreck of the Henrietta Marie (Key West, Florida: Mel Fisher Maritime Heritage Society, 1995)

Figure 6.1. William Jackson, A Liverpool Slave Ship, 1780. Oil on Canvas, $102 \mathrm{~cm} \mathrm{x}$ $127 \mathrm{~cm}$, Merseyside Museum, Liverpool UK. .101

Figure 6.2. Jean Bourdroit, The Rear of the Slave Ship Aurora, Monograph, reproduced from Jean Boudriot, Monographie De L'Aurore- Navire negrier-1784 (Nice, France :Ancre) 95.

http://www.histoiremaritimebretagnenord.fr/activit\%C3\%A9s-maritimes/la-guerreen-mer/.....

Figure 6.3. Jean Bourdriot, Aurore Monograph, monograph, reproduced from , reproduced from Jean Boudriot, Monographie De L'Aurore- Navire negrier-1784 (Nice, France :Ancre) 95.

Figure 6.4. The Fredensborg II, 1788, painting, in Leif Svalesen, The Slave ship Fredensborg, (Kingston Jamaica: Ian Randle publishers, 2000), 104..............106

Figure 6.5. William Fox, Revolt Aboard Slave Ship, 1787, 1851, lithograph, in A Brief History of the Wesleyan Mission on the West coast of Africa (London, 1851), 116. Accessed January 2013. http://hitchcock.itc.virginia.edu/Slavery/details.php?categorynum=5\&categoryName= $\&$ theRecord $=6 \&$ recordCount $=78$. 108

Figure 6.6. Pretexat Oursel. Transport des Negres dan les Colonies, ” Color lithograph, in Anneaux de la Memoire: Nates-Europe-Afriques-Ameriques, Chateau des Ducs de Bretagne, (Nantes, France 1992).

http://hitchcock.itc.virginia.edu/SlaveTrade/collection/large/E009.JPG .109

Figure 6.7. William John Huggins, The Capture of the Slaver Formidable by HMS Buzzard, 17 December 1834, Oil on canvas on panel, $380 \mathrm{~mm}$ x $545 \mathrm{~mm}$, National Maritime Museum, Greenwich, London, Macpherson Collection, http://collections.rmg.co.uk/collections/objects/12117.html .

Figure 6.8. The anchorage off the Town of Bonny River sixteen miles from the Entrance, water color with graphite, 200mm x 370mm, National Maritime Museum, Greenwich London, http://collections.rmg.co.uk/collections/objects/106080.html...111

Figure 6.9. Ile St. Louis near the mouth of the Senegal River, 1814 "Vue de l'île St. Louis du Sénégal prise de côte de la mer." René Claude Geoffroy de Villeneuve, Illustrations de L'Afrique ou histoire, moeurs, usages et coutumes des Africains. Nepveu. Paris, 1814. Bibliothèque Nationale de France (ark:/12148/cb38495427c) 
Figure 6.11. Dansa de Negres, 1837, Illustration, in Amedee Grehan, La France maritime, 3(1837), 179.

http://hitchcock.itc.virginia.edu/Slavery/details.php? categorynum=5\&categoryName= \& theRecord $=12 \&$ recordCount $=78$ 113

Figure 6.12. View of Cap Francais and the Marie Seaphique of nantes/Captain Gaugt/ the day of the opening of its slave sale after its third voyage from Angola, 1772, 177, 1772, watercolor, in Madeline Burnside, Spirits of the Passage, (New York, 1977), 124. http://hitchcock.itc.virginia.edu/Slavery/details.php? categorynum $=5 \&$ categoryName= \& theRecord $=24 \&$ recordCount $=78$ .115

Figure 6.13. Capture of a Large Slave-Ship by the HMS Pluto, 1860, print, in the Illustrated London News 36 (April 28, 1860), 406. http://hitchcock.itc.virginia.edu/Slavery/details.php? categorynum $=5 \&$ categoryName $=$

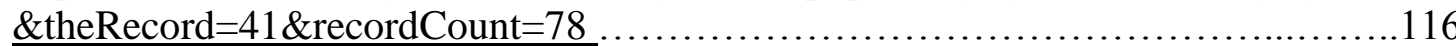

Figure 6.14. Richard Drake, Scene in the Hold of the 'Blood-Stained Gloria' (middle passage), 1860, Print, in Revelations of a Slave Smuggler (New York, 1860), 28. http://hitchcock.itc.virginia.edu/Slavery/details.php?categorynum=5\&categoryName=

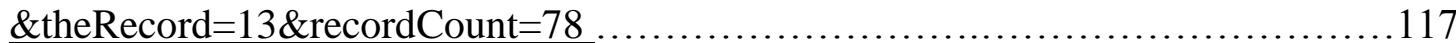

Figure 6.15. Negres a fond de calle, 1835, Lithograph, in Robert W. Slenes, African Abrahmas, Lucretias and Men of Sorrows, Allegory and Allusion in the Braziliam Anti-slavery Lithographs (1827-1835) of Johann Moritz Rugendas, (Slavery \& Abolition, vol. 23, 2002), 147-168. http://hitchcock.itc.virginia.edu/Slavery/details.php?categorynum=5\&categoryName= \&theRecord $=15 \&$ recordCount=78Figure

Figure 6.16. J.F. Ade Ajayi \& Michael Crowder, On Board a Slave Ship, in Historical Atlas of Africa (Harlow, Essex, England, 1985)................................ 118

Figure 6.17. Henry Howe, Stowing the Cargo of a Slaver at Night, 1856, Engraving, in Life and Death on the Ocean: A Collection of Extraordinary Adventure in the Form of Personal Narratives, (Cincinnati, 1856).

http://hitchcock.itc.virginia.edu/Slavery/details.php?categorynum=5\&categoryName= \&theRecord $=14 \&$ recordCount $=78$

Figure 6.18. Lt. Francis Meynell, Slave deck of the Albaroz, Prize to the Albatross 1845, 1845, Pencil and Water color, at National Maritime Museum, London, http://hitchcock.itc.virginia.edu/Slavery/details.php?categorynum=5\&categoryName= \&theRecord $=23 \&$ recordCount $=78$ 


\section{CHAPTER 1}

\section{INTRODUCTION}

This study examines the structure, construction, and modification of vessels used in the slave trade and analyses how those vessels changed over time. It also takes into consideration the material cultural associated with slave ships both in the historical record and the archeological record. Given the extensive recent scholarship on the construction of race in America, it is appropriate for this study to also consider what if any influence the historical developments of racial conventions had on the building of these vessels and vice versa.

The hypothesis that the ships used in the slave trade changed in correlation with the ideas of race and economic need forms the basis for this study. These changes were reflected in the ship structure (i.e. size, angle of the stem post, arrangement of crew and cargo), modifications made to vessels during different legs of the voyage (arrangement of freight, fortifications, number of guns, netting, walls, etc.), and the commissioned purpose of the ship (ships built to go to Africa vs. ships fitted to go to Africa).This thesis looks primarily at vessels from the Anglo world (England and New England). The Middle Passage is something witnessed in movies literature and first person accounts. In the archeological record, it is not experience it as readily.

When the Middle Passage is addressed in books and movies, the focus is often on the experience that took place on a ship rather than the ship itself. The reasons for this emphasis are threefold. First, the experience of people taken from Africa and forced into slavery is important and compelling. Their experiences shaped our nation 
and are still important, relevant and poorly understood. Second, the lack of records and interest in the ships themselves has pushed the subject aside. Abolitionists, painted a picture for the world of what it is like on a slave ship. These same abolitionists subsequently shaped the social memory of these ships. Certainly, conditions and circumstances on board slave ships were horrific, as abolitionists point out, but the abolitionists' emphasis was on abolishing slavery rather than developing a fully accurate representation of the construction and fitting of slave ships. Third, the national shame associated with the slave trade requires an emphasis on slave experience. In the United States, the slave trade was a family business, and even today families are reluctant to admit their participation, however, large or small. In Liverpool, slave ship investors were often involved in many ventures, the historic profits of which still benefit business and institutions today. These factors make records of slave ships difficult to locate if they survive at all. Despite their significance in the world's economic and cultural landscape, few examples of slave ships exist in the archeological record. Combined with the targeting of these vessels by treasure hunters, it becomes clear why there is so little knowledge regarding the structure and construction of these vessels.

This study will begin answering some of the questions about the design, construction and modification of slave ships. The slave trade is a vast, and allencompassing topic. Only when the evidence is examined from new angles can important patterns and trends appear, as can assertions about the nature of shipbuilding for the slave trade. Approaching the subject of study within a global rather sitespecific or regional framework allows for conceptualizing wide-ranging processes and 
patterns that affected people and trends on even the smallest scale. ${ }^{3}$

\section{BACKGROUND}

Scholars have debated the reasons for the transatlantic slave trade since before its abolition. Those who emphasize racism and/or economic opportunity have valid arguments. ${ }^{4}$ Once established, the trade grew. The growth of the slave trade came from the need for labor in the plantation economy in the Americas combined with Europeans perceptions of racial superiority and their advantages in economic and technological know-how. ${ }^{5}$ European maritime expansion allowed sailors to embark on longer voyages across the open ocean. More places became reachable, and the ocean became a highway instead of a hindrance.

In the eyes of European's Africans made ideal labors, they came from a climate that was more like that encountered in the Caribbean, the American South, and South America. Africans had contact with Europeans for much longer than American Indians and Caribe's and so did not die as readily from disease. ${ }^{6}$ Africans were also eligible for enslavement in a ways other groups were not. Africans do not look like Europeans; they do not share a language or a religion, making it much easier to justify enslaving them. ${ }^{7}$ Further, the ability to geographically isolate captives from their home minimized problems such as retribution from kinships groups, rescue attempts, and

\footnotetext{
${ }^{3}$ Christopher DeCorse, The Archaeology of Elmina (Elliot Werner Publications, 2001), 11.

${ }^{4}$ Winthrop D. Jordan, White Over Black: American Attitudes toward the Negro, 1550-1812 (Chapel Hill: North Carolina Press, 1968), 53.

${ }^{5}$ Greg Cook, "The Maritime Archaeology of West Africa in the Atlantic World: Investigations at Elmina, Ghana," (PhD diss., Syracuse University, 2012) 45.

${ }^{6}$ David Eltis, "The Enslavement of Africans: A Brief Overview of the Trans-Atlantic Slave Trade, " A Brief Overview of the Trans-Atlantic Slave Trade (online: Emory University, 2007).http://www.slavevoyages.org/tast/assessment/essays-intro-02.faces.

${ }^{7}$ David Eltis, "Early Slaving: A Brief Overview of the Trans-Atlantic Slave Trade, " A Brief Overview of the Trans-Atlantic Slave Trade (online: Emory University, 2007), http://www.slavevoyages.org/tast/assessment/essays-intro-02.faces.
} 
familiarity with the landscape which could aid escape. Africans were also active agents in the trade; they had influence and power in interactions with Europeans more than simply trading trinkets. Coastal African communities used interaction and trade relationships with

Europeans to expand and consolidate power. ${ }^{8}$

Between 1540 and 1850 an estimated 15 million people were taken from Africa and brought to forced labor in the western hemisphere. By the

Seventeenth-century slaves purchased in Africa were resold in the Americas for three times the amount of purchase. The demand created by the plantation

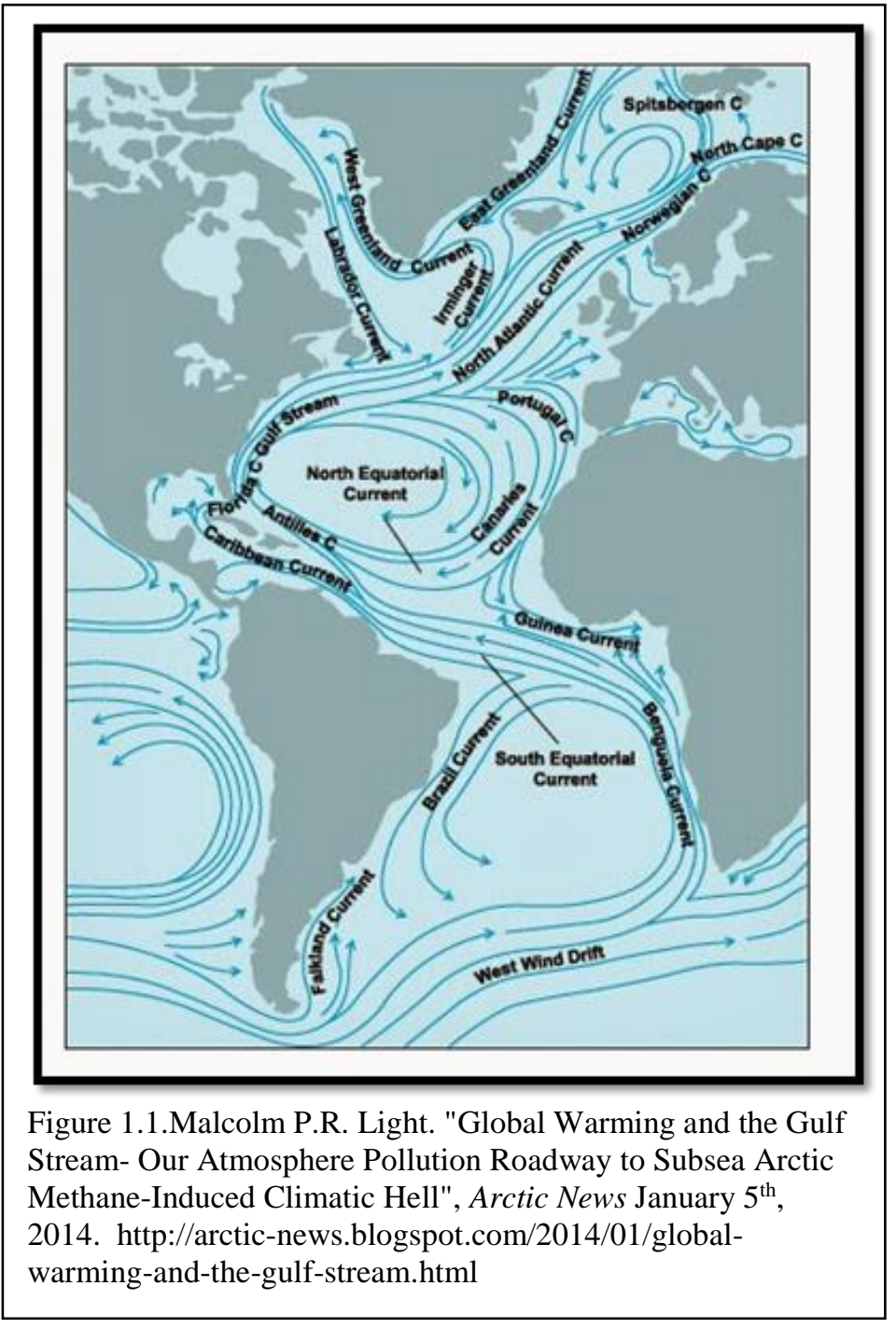
economies in the colonies insured that there was a continuous demand for African slave labor. This continuous demand filled the pockets of merchants and stimulated more voyages to Africa, further driving the trade and capitalizing on the commercial opportunity.

${ }^{8}$ Christopher DeCorse, The Archaeology of Elmina (Elliot Werner Publications 2001), 13. 
European advancements in seafaring also made the slave trade possible. Improvements in navigation, mapping, and timekeeping, allowed Europeans to sail further and expand more aggressively. While exploration was originally driven by the "need" for a quicker route to the east, Europeans also developed knowledge of Africa and the western Atlantic. New resources, new economic markets and new colonial enterprises opened up. As European empires emerged, different countries experimented with and adopted different ideas of ship design. These adaptations lead to the development of ships that could travel faster and stay at sea longer.

The systems of wind and current in the North and South Atlantic aided Europeans in seafaring and were a determining factor as to which countries traded in which markets. The Atlantic Ocean is home to two circular currents (Figure 1.1). The Northern Atlantic moves in a clockwise direction, driven by Gulf Stream. The South Atlantic moves in a counter-clockwise direction and is driven by the Brazil Current. The English and other northern European nations utilized the Gulf Stream to travel down to Africa and later to return to Europe while the South Atlantic currents were used almost exclusively by the Portuguese to traffic to Brazil.

Aided by the wind and ocean currents of the Atlantic, two major slave trading centers developed. The first was the Portuguese slave trade centered on markets in Brazil and the second is rooted in Northern Europe centered on markets in North America and the Caribbean. These two routes also influenced where slaves came from and where they were relocated. There was of course overlap, but Brazilian imported slaves came predominantly from Angola. Africans brought to North 
America, and the Caribbean came primarily from West Africa and most importantly the Bights of Biafra and Benin and the Gold Coast.

As exploration and technological development opened the world, economic markets and goods expanded as well becoming increasingly more specialized. Economic expansion of the slave trade, led to the development of merchant houses dedicated solely to economic enterprises on the African coast. The more the market increased, the more voyages per year ventured to Africa and the Americas. To obtain the greatest profit margins merchants built ships that would best utilize the wind and currents leading to shorter journeys and lower slave mortality rates.

A 'Special Purpose Vessel' is a military term applied to vessels that are specialized both in structure and function to perform a specific job. In the modern day, special purpose vessels include icebreakers, cable ships, and aircraft carriers. This term can also be applied to other vessels that performed special functions before the modern military area. A special purpose ship, is a ship that was built for one specific purpose and is so specialized in construction that it can either not be used for any other purpose (on a commercial level) or it must undergo specific modifications and alterations to be used for a purpose other than for which it was built. A special purpose ship has specific characteristics that make it suitable for its purpose that would be superfluous to other uses or increase its commercial viability for one specific task.

While concept of a special purpose ships is something that has usually been applied to ships built after the First World War the same ideas of differentiated purpose and design can be said of some ships of the Seventeenth, Eighteenth and Nineteenth century. While this study does not address ships prior to those used in the 
slave trade or in other cultures, it could be argued that every seafaring culture has had some degree of special purpose ship.

When previously discussed in ship building theory literature, the idea of a special purpose vessel is proposed to begin in the middle of the Eighteenth century. ${ }^{9}$ Before the mid-Eighteenth-century ship building, it is argued, was more of a craft and the design was left wholly up to the shipbuilder. Naval architectural design was not affected by 'science' until the Nineteenth century. ${ }^{10}$ However, when looking at ships during earlier periods it is clear that special purpose vessels did, in fact, exist and were further adapted for the purposes for which they were created as time passed.

"Ships are designed to meet the requirements of owners or for war and their features are dictated by these requirements." 11 This has been the case since the first time that man took to the seas. Until the invention of the aircraft, ships were the most advanced form of technology produced by humankind. In addition, ships underwent adaptive measures to become more specialized and serve the purposes of the people using them.

When examining ships from before the mid-Eighteenth century the most specialized ships are those used in war and conflict and merchant vessels, although it could be argued that fishing vessels were just as adaptive. 'The Purpose of a merchant ship has been described as conveying passengers or cargo from one port to another in the most efficient manner.' If this is, in fact, the purpose of a merchant vessel, the most efficient manner would require specialized equipment, knowledge, and skills.

\footnotetext{
${ }^{9}$ K.J Rawson and E.C.Tupper. Basic Ship Theory Vol. 1 \& Vol. 2. (New York: Longman Inc., 1976), 1. ${ }^{10}$ Ibid., 1.

${ }^{11}$ Ibid., 3.
} 
'The economics of the trading of the ship itself have an effect on its design.' 12

In the case of slave ships, our current knowledge of the actual construction of the ships is very limited. There is much we can learn, however, about the differences in these ships by looking more deeply into historic records, the archeological record and representations of the ships in art. While it would be impossible to compare every ship, it is feasible to look at a cross section of the slave ships and analyze what makes them unique and specialized.

This study utilized historical records from the Newport Historical Society, the Rhode Island Historical Society, and the National Maritime Archives in Liverpool, England. Records held in these locations point to other documents, related to specific families and individuals. Many of those records are held in local historical societies and museum. Accessing and using them presented its own challenges; many families are still hesitant to allow their families name to be associated with the slave trade. This is particularly true in New England, where many families still reside. In most cases, using family records was either difficult or virtually impossible.

This study utilized archaeological evidence from every instance of a slave ship that has been discovered and published. The only exception is a ship recently discovered off the coast of South Africa, data from which was not available in time to incorporate. None of the wrecks included in this study sank while working as a slave ships, but they still offer information related to the building and outfitting of slave ships.

${ }^{12}$ Ibid., 3. 
The majority of the art used was compiled by the University of Virginia, but any art that was discovered in the process of the research and could be verified through the historiography, was also included. More art and documents will come to light in time, providing an opportunity to update this research and expand our knowledge. 


\section{CHAPTER 2}

\section{HISTORIOGRAPHY OF THE SLAVE TRADE \& SLAVE SHIPS}

The study of the African slave trade has fascinated scholars since before its abolition. Each country involved in the African slave trade has its own historiography and each had a particular role that it played and a unique perspective. For this study those that are most important are those of the Anglo world, namely England and the current United States of America.

The historiography varies slightly from country to country; this variation is related to each country's level of participation in African slavery, In England, the study is often more related to individual ports, primarily of Liverpool and Bristol, and economic impacts. American scholars have been more concerned with the study of the cultural and social implications of the slave trade and how those relate to individual slavers, slaves, and plantations. ${ }^{13}$

Scholars of the slave trade can be divided into four distinct groups antiquarian chroniclers, political historians, economic historians, and the social historians. With the exception of Abolitionists, most antiquarian chroniclers were Victorian merchants and contemporaries of the African slave trade who do not address the trade directly. Nonetheless they provide information about the trade. Antiquarian scholars usually include a discussion of the slave trade prior to that of the African slave trade, particularly the Roman slave trade, and discuss the nature of slavery.

\footnotetext{
${ }^{13}$ James Rawley and Stephen D. Benrendt, The Transatlantic Slave Trade: A History (Lincoln: University of Nebraska Press 2005), 12.
} 
Antiquarian scholars are often used in arguments that supported the slave trade and slavery. ${ }^{14}$ Abolitionists, on the other hand, studied the slave trade in order to show how deplorable the conditions were and to create an argument against it. Their objective was to establish the moral argument against the importation of humans for the purpose of labor and to combat the economic argument that encouraged it. ${ }^{15}$

Antiquarian historians often offer general observations about the slave trade with little interpretation; they include copies of documents and journals or publish the documents and journals that they wrote. In Elizabeth Donnan's “Documents Illustrative of the History of the Slave Trade to America" this is the case. Donnan's collection, in four volumes, looks at primary documents without offering synthesis or interpretation. While Donnan's work generates a conversation about the slave trade, it fails to contribute more to the discussion than evidence of what occurred and who participated. ${ }^{16}$

Political historians or political narrators of the slave trade are more descriptive than analytical and are unconcerned with the social and cultural impact of the trade, in general. Often a sense of black agency is missing from these discussions and instead slaves are helpless and pure victim. Abolitionist also can fall into this category. The

\footnotetext{
${ }^{14}$ George Fitzhugh. Sociology for the South, or, the failure of Free Society. (Richmond, VA; A. Morris, 1854).

George Fitzhugh, Cannibals All! or, Slaves Withough Masters (Richmond: A Morris, 1857).

Ebenezer W. Warren, Southern Slavery and the Bible: A Scriptural refutation of the Arguments upon which Abolitionists Rely: A Vindication of Southern Slavery from the Old and New testaments (Macon: Burke, Boykin \& Company, 1864).

15 James Savage, "The English Slave Trade" in Memorabilia, or Recollections, Historical, Biographical, and Antiquarian (London: Baldwin, Cradock \& Joy, 1822) 25.

Hennery Meredith, An account of the Gold Coast of Africa: with a brief history of the African Company (London: Printed for Longman, Hurst, Rees, Orme, and Brown, 1812).

Archibald Alexander, A history of colonization on the western coast of Africa (Philadelphia, W.S. Martien, 1846).

${ }^{16}$ Elizabeth Donnan, Documents Illustrative of the History of the Slave Trade in America (New York: Octagon, 1965).
} 
Slave Trade Debate by John Pinfold is an excellent example of this; it is a collection of pamphlets published in regards to the Abolition of the Slave Trade Act in 1807. It looks at the political position of both abolitionists and those in favor of continuing the trade, addressing what each side argued and how it affected the outcome of the legislation. ${ }^{17}$

Economic historians usually utilize quantitative techniques to chart involvement in the trade and explain the rise and fall of different slaving ports.

Focused more an established parameters of the slave trade and the economic impacts, economic historians often neglect cultural and personal experiences. Their studies generally focus on compiling lists of data and information about voyages, captains and trade routes. Again these studies are not concerned with individuals any more than their role as business decision makers or a source of profit and loss. The website www.slave voyages.org is the most inclusive of this type of scholarship, as it is simply the compilation of all the data currently available regarding the Atlantic slave trade.

Detailed discussion of "race" is in many of the studies of slavery, but tends not to be included in scholarship of the slave trade. Marcus Rediker's The Slave Ship is perhaps an exception. While he uses stories and accounts of the middle passage to discuss race and illustrate the agency of individuals on ships crossing the Atlantic, he does not look at the ship itself other than as a vessel of confinement. ${ }^{18}$ Social historians, like Rediker, are by far the most prolific in dealing with the slave trade and

\footnotetext{
${ }^{17}$ John Pinfold, The Slave Trade Debate: Contemporary Writings for and Against (New York; Bodleian Library, 2008). Other Political Historians include:

JR Oldfeild, Popular politics and British anti-slavery: the mobilisation of public opinion against the slave trade, 1787-1807 (New York: Manchester University Press 1995).

Paul Finkelman, The African Slave trade and American Courts: the Pamphlet literature (New York: Garland Pub., 1988).

${ }^{18}$ Marcus Rediker, The Slave Ship: A Human History (New York: Penguin, 2007).
} 
in recent years they have used multiple venues for dissemination of their ideas, including popular media. First person accounts such as that of Olaudah Equiano have famously brought life to the story of the middle passage and the African slave trade. ${ }^{19}$ None of these include a significant amount of information or interpretation on the preparations for the trade. A look at the structure of the slave ship itself, the modifications, and the construction is an apparent gap in the historiography. Including information about the implications the construction and modifications to these vessels have on conceptions of race and the mindset of slave trading merchants also appears to be both neglected and worthwhile.

The Slave Ship Brooke's is probably the most recognizable image related to the slave trade and its abolition. This image appears over and over in the discussion of the slave trade. It was used to describe the conditions on board slave ships in England and was seized upon by abolitionists worldwide. It was published and re-published all over the world by different groups who opposed the slave trade as evidence of the barbaric nature of the slave trade. The image of the Brooke's as a plan view is so popular few other images come to mind when discussing the structure of a slave ship. Even today the image can be found enlarged to near life size in museums and books the world over. This image represents the sole example of the structure of slave ships used by antiquarian historians.

${ }^{19}$ Olaudah Equiano, The Interesting Narrative of the Life of Olaudah Equiano, or Gustavus Vass, the African (New York: Penguin Books, 2003). 


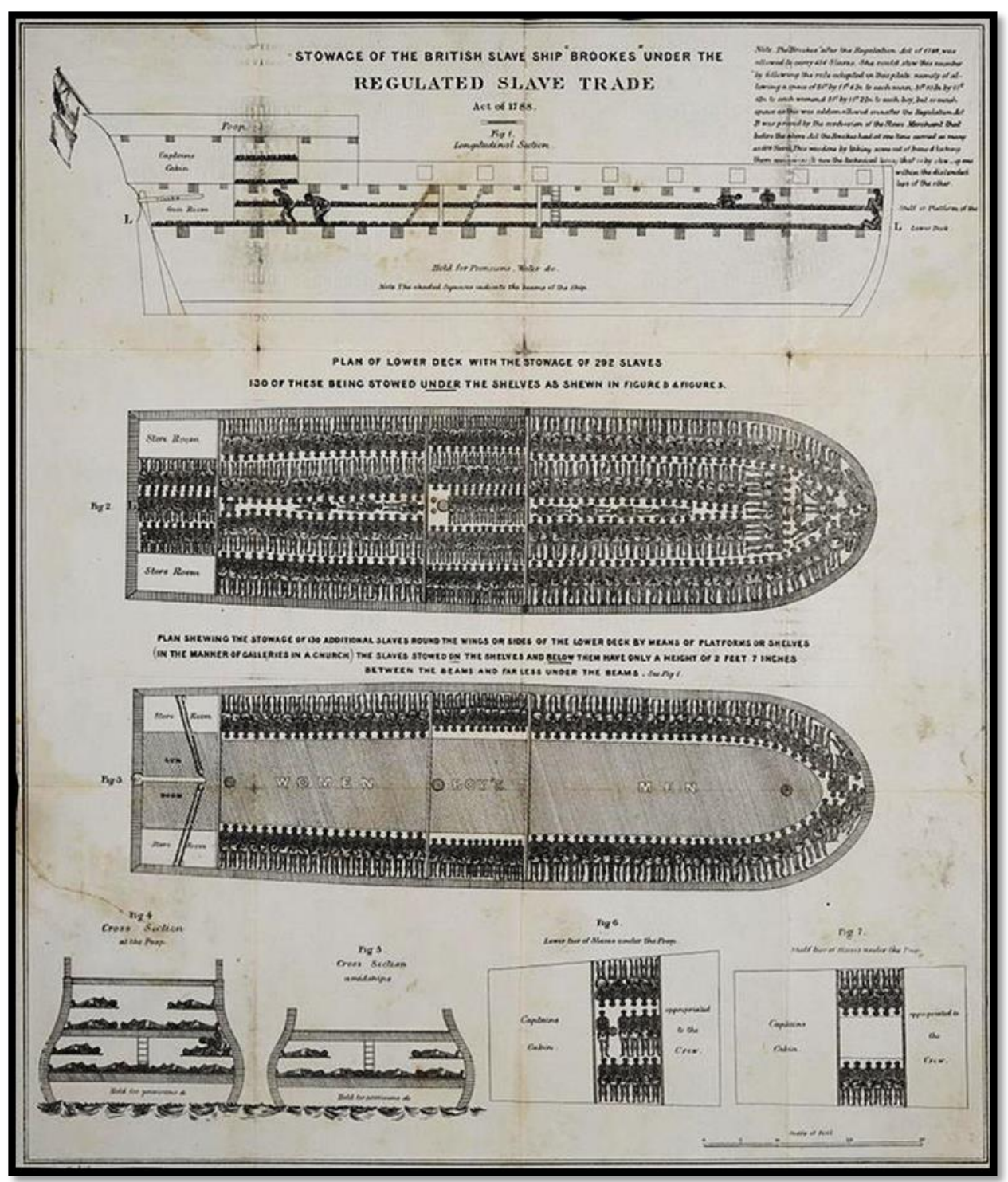

Figure 2.1: William Alfred. Stowage of the British Slave Ship 'Brookes' under the Regulated Slave Trade, Act of 1788, 1790, Lithograph, Broadside Collection, Rare Books and Special Collections Division, Library of Congress.

The image was first produced in England in 1788 by William Alfred, a banker

in Plymouth England. Alfred was a fellow of the Royal Society and a fellow of the

Royal Academy. As an established painter Alfred was someone who could portray

the truth of the slave ship. He was curious to see the condition of slave ships after the

establishment of the Dolban Act in Britain in 1788 (also known as the Slave Trade Act 
1788). ${ }^{20}$ The Dolban Act stated that: for every three tons of draft in a vessel only five slaves could be stored. ${ }^{21}$ After visiting the wharf in Liverpool, Alfred studied stowage diagrams and completed the image of the plan view of the ship.

The Brooks was not the largest or smallest of the ships it was simply the first on the list and thus the reason for

Alfred's selection .A British Naval Officer took the

measurements. The original diagram was printed along with twelve hundred

words about the conditions on board.

Viewed as an

eyewitness

testament, no moral or special pleading included, it was a

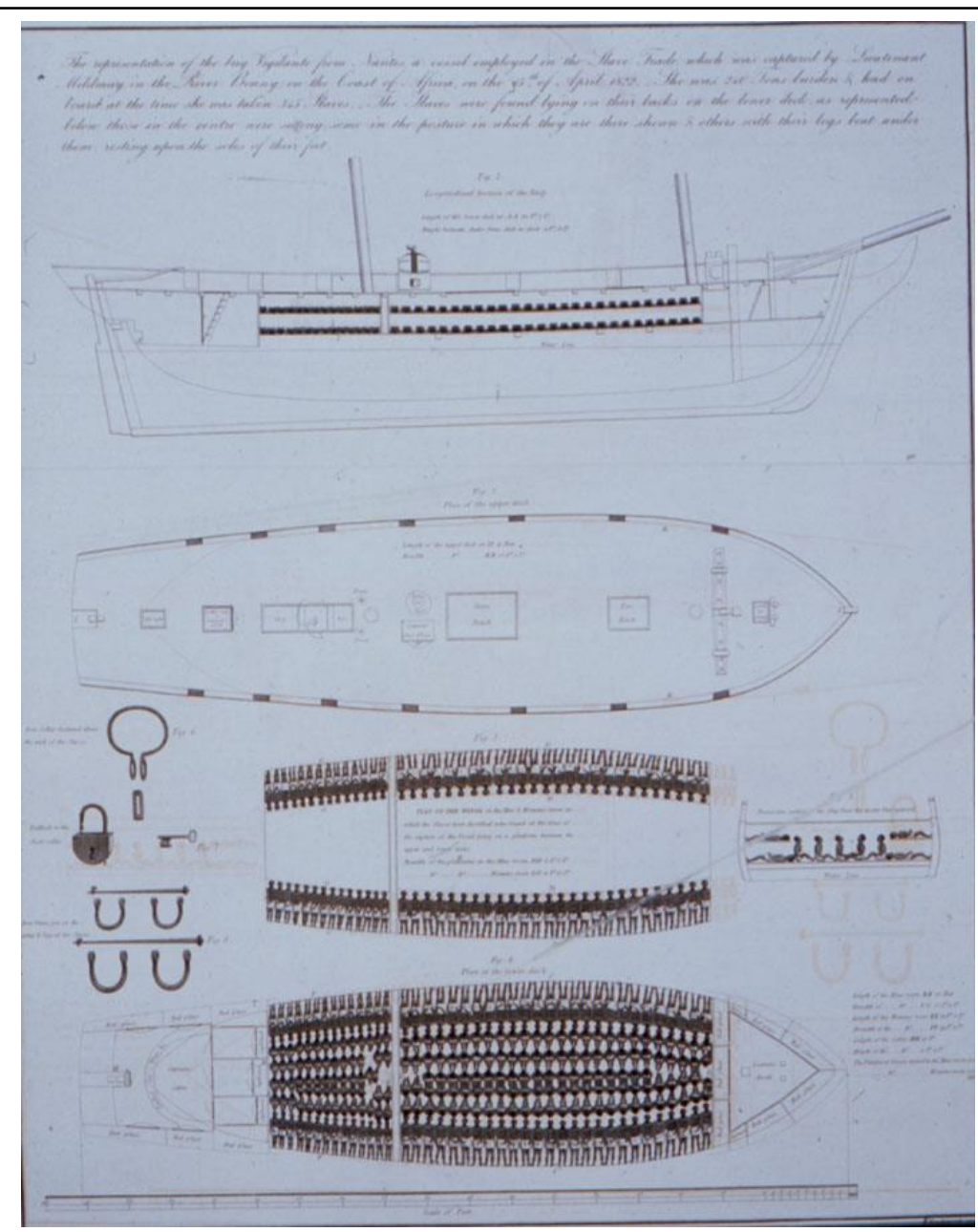

Figure 2.2: Committee of the Religious Society of Friends in London. Case of the Vigilante, a ship employed in the slave trade; with some reflections on that traffic, 1823, Boston Public Library.

${ }^{20}$ Charles Garland and Herbert S. Klein, "The Allotment of Space for Slaves aboard EighteenthCentury British Slave Ships,” The William and Mary Quarterly 42 (1985): 238-248.

${ }^{21}$ The Statutes at Large From the Twenty-fifth Year of the Reign of King George the Third (London, Strahan \& Woodfall, 1785), 512. Accessed Dec. 15, 2014 https://play.google.com/books/reader?id=eqZFAAAAcAAJ\&printsec=frontcover\&output=reader\&hl=e n\&pg=GBS.PP5 
unique approach. The purpose was to present a forensic case, which had no reference to religion and presented the facts in a non-emotional way.

Published in the American Museum, the most popular and wildly circulated magazine of its time, it was the original version from Bristol. The Philadelphia Committee for the Abolishment of the Slave Trade presented the image to the White House because the image was an appeal that was thought to work on men more than a woman as it did not appeal to emotion and woman responded more to the sexually violent nature of the trade.

Thomas Clarkson was in charge of improving the diagram for distribution in London and added the sectional view of the ship to the diagram. The improved graphic was the beginning of a plan to get Parliament to talk about the slave trade. With each subsequent publication, the image grew in popularity and meaning until it was the sole image that most people associate with the structure of a slave ship. ${ }^{22}$

The London Committee is a group of middle class men that took it upon themselves to pressure the political powers of Eighteenth century England to abolish the slave trade (also known as the Abolition Committee). Created on the 22 of May 1787, the original group of mostly bankers and merchants set their sights on rallying public opinion against the slave trade. This occurred by organizing petition campaigns against both the English Parliament and the House of Commons as well as by 'procuring such information and evidence... as may tend to the abolition of the slave trade." 23 The London Committees version is seven diagrams and has a 2400 word accompaniment, and was presented to Parliament and the House of Commons as

\footnotetext{
${ }^{22}$ Michael Suarez, "The Print that Changed the World: The Description of the Slave-ship Brookes," (Lecture, Brown University, Providence RI, Nov. 12, 2013).

${ }^{23}$ Abolition Committee Minutes, 22 May 1787.
} 
evidence against the slave trade. It has more statistics and depicts a realistic ship. The more the image was "improved upon" the further it drifted away from an accurate representation of the Brookes.

There are some problems with this image. It depicts 487 slaves when in actuality on the journey before the measurements were taken there were 638 slaves on board. The following journey had 744 slaves on board. The first journey after the measurements were taken, 609 slaves were on board. None of these numbers correspond with that allowed under law according to the tonnage of the ship, which, as set by the Slave Trade Act of 1788, was 1.67 slaves per ton up to a max of 207 tons burthen after which 1 slave per ton could be carried. ${ }^{24}$

The outer planking is much too thick and is not proportional to the rest of the vessel. The stowage of slaves on multiple decks contradicts the commonly practiced methods of storing water and provisions. There are no deck hatches illustrated, only small ladders, which means that the ship would have had no way to load and unload the material and provisions required, especially for those legs of a journey that did not have slaves on board. Finally the cross sections at the center of the vessel and at the poop deck accurately show that slaves are stored in these locations, but no racks would have been in place on the poop deck. Instead sailors would sleep in this space in hammocks and children would be on the floor below them.

Despite the images inaccuracy, it was so popular that it was put up in public places and on streets, as well as in magazines and books. After 1808, the image of the Brookes was paired with other images and the text disappeared. This inspired all

\footnotetext{
${ }^{24}$ Raymond Cohn, "Deaths of Slaves in the Middle Passage," The Journal of Economic History. 45:3(1985): 685-692.
} 
future publications of ships to have a plan view and a cut away. In 1830, the individual faces begin to appear in the lithography, amplifying the message through the new medium. Finally, the image was used in the 1853 abolition

movement and historians have viewed it as sufficient for understanding the

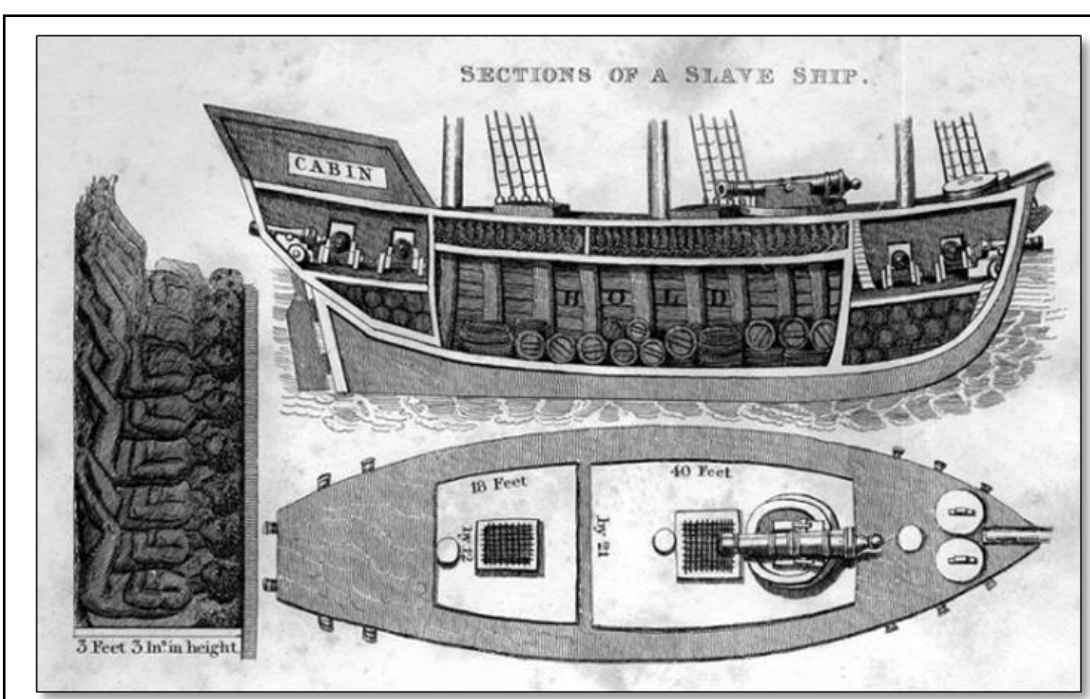

Figure 2.3: Robert LL.D. Walsh. Notices of Brazil in 1828 and 1829. 1829, Print, British Library, Historical Prints Editions.

structure of a

slave ship. ${ }^{25}$ Today, the graphic is so ubiquitous that few other images of slave ships are used or considered.

There are other significant images, but none as popular as the Brookes. In 1826, an image of the ship Vigilante (Figure 2.2) introduced the images of shackles and the shackling of individuals ankle to ankle and wrist to wrist. $^{26}$

The Vigilante was captured by LT. Mildmay in the River Bonny on the coast of Africa on April $15^{\text {th }} 1822$. She was 240 tons and had 345 slaves on board at the time.

Published as a foldout, first in Paris in 1823 and later in London in 1826, details on the

\footnotetext{
${ }^{25}$ Michael Suarez, "The Print that Changed the World: The Description of the Slave-ship Brookes," (Lecture, Brown University, Providence RI, Nov. 12, 2013).

${ }^{26}$ Committee of the Religious Society of Friends In London, Case of the Vigilante, a ship employed in the slave trade; with some reflections on that traffic (London: Harvey, Darton, \& Company, 1823), 2.
} 
dimensions of each deck and space allotments are included. Abolitionists used this image for the same way and to serve the same purposes as the Brookes before it.

Scenes of Africa in children's book began to include images like that of the Brookes but did not include the people aboard in such detail. ${ }^{27}$ In the second quarter of the Nineteenth century, images of the slave ship cross sections penetrated even formal societies and respected publications. Typically, however, these images were either reduced for publication, changed for the sensitivities of a gentler audience and/or were drafted by authors who had never been aboard a slave ship. An excellent example of this is in Robert Walsh's image (Figure 2.3) "section of a slave ship". ${ }^{28}$ Published in Walsh's Notices of Brazil in 1828 facing the title page, it is an image that conveys the tight quarters that captives were subjected. It is not proportional and is missing many of the elements that any ship would have, especially a slave ship. The canon on the top deck is nearly 20 feet long, according to the measurements in the image. If this is the case the gun is longer than the ship is high. The deck height of the slave deck is said to be 3 feet and 3 inches, which would make the hold below it nearly 10 feet high. If the ship was constructed to these proportions it would not be able to sail.

Looking at the slave trade through the mode by which captives were transported across the Atlantic gives insight into some of the driving reasons for the trade itself. The ship was a way to separate out culture, to drive economic profits, and to promote

\footnotetext{
${ }^{27}$ Michael Suarez, "The Print that Changed the World: The Description of the Slave-ship Brookes," (Lecture, Brown University, Providence RI, Nov. 12, 2013).

${ }^{28}$ Robert LL.D. Walsh, Notices of Brazil in 1828 and 1829 (London: British Library, Historical Prints Editions, 2011), 2.
} 
racism. The study of the slave ship as a unique vessel provides insight to any historical attempt to address the complexities of the slave trade. 


\section{CHAPTER 3}

\section{ARCHAEOLOGICAL INVESTIGATIONS OF SLAVE SHIPS}

Shipwrecks offer a unique opportunity to view an assemblage of artifacts from a single moment in history. While many different items were imported to Africa and used in the trade for slaves, a select few are preserved in the archeological record. This is especially true in the underwater environments where items like cloth, livestock, foodstuffs, salt, rum and gin rarely survive. However, brass, iron, glass, gold, and other non-organic materials fare much better. These items are often harder to date but can give researchers other significant information. These items have not been studied sufficiently to come up with a tight typology to use them as datable items. Therefore, slave trade artifacts generally provide limited information.

Those items that do survive in the submarine environment, when discovered alone, may not immediately identify a ship as a slaver. Naturally, items viewed in context with other items, can be used to identify the vessel as a possible slave ship, and possibly a specific identification. This information includes information as to where a particular ship was planning to trade, where it may have come from, and what other markets it was involved in? The archeological evidence of trade goods can give information about the quantity of slaves being traded, as well as the period in which a ship was in use. Artifact types that do preserve in the archeological record and can tell archeologists about trade with Africa and the Americas and its relationship to the currencies used to purchase slaves. 
There are few slave ships wrecks that have undergone archeological investigation. Two wrecks that have been published on and identified as active in the transatlantic slave trade at the time of wrecking are the Henrietta Marie and the Fredensborg. The Henrietta Marie was lost in 1700 off Key West. The Fredensborg was wrecked in 1768 off the Isle of Tromoy, Norway. ${ }^{29}$ Neither of these ships wrecked with slaves on board. However, both offer information about the slave trade and the transition ships made during different legs of their journey around the Atlantic.

Archaeologists have investigated several ships that were formally slavers but sank while working in a different maritime market. The Adelaide wrecked near Cuba in 1714 was discovered in 2003 by Frank Goddio. At present, all that is published about the Adelaide is what appears on Goddio's blog. ${ }^{30}$ The Whydah, a former slaver captured and turned pirate ship, wrecked in 1717 and subsequently salvaged, was rediscovered in 1985 by Maritime Explorations, Inc. ${ }^{31}$ A French/Portuguese slave-ship the James Mathews sank in 1841 on a voyage to Australia. It had been captured in 1837 by the British Royal Navy and sent to Liverpool to be condemned and rebuilt. ${ }^{32}$ The now famous Queen Ann's Revenge another slaver turned pirate vessel ran aground and was abandon of the shores of North Carolina in 1717 by the infamous pirate Blackbeard.

Some wrecks salvaged at the time of the wrecking event or excavated/salvaged

\footnotetext{
${ }^{29}$ Jane Webster, "Historical Archaeology and the Slave Ship," International Journal of Historical Archaeology 12:1(2008): 3.

30 Jane Webster, "Slave Ships and Maritime Archaeology: An Overview” International Journal of Historic Archaeology 12:1(2008): 12-14.

${ }^{31}$ Bob Cembrola, "The Whydah is for Real: An Archaeological Assessment," Seafarers, Journal of Maritime Heritage Volume 1. Accessed Jan. 2014, http://atochagold.com/TheWhydah.html

${ }^{32}$ Graeme Henderson, "The Wreck of the Ex-Slaver 'James Matthews,"” International Journal of Historical Archaeology 12(2008): 41- 45.
} 
prior to what is considered modern underwater archeology give information that is hard to decipher or have large holes in the investigation. Using what remains of these collections and the historic documents, a reevaluation of many of the wrecks has taken place. The Enterprise is one such ship. She sank in 1803 near Copeland Islands, Ireland. ${ }^{33}$ She was first salvaged in 1834 by a local salvaging group, meaning there is very little documentation related to vessel other than the money made from the recovery. ${ }^{34}$ Another vessel salvaged soon after wrecking was the slave ship Trouvadore. The Trouvadore sank in 1841 after she ran into a reef off Turks and Caicos while attempting to go avoid British Royal Navy vessels searching for ships involved in illegal slaving. ${ }^{35}$

Most archeologists and historians have relied on post-fieldwork research in archives and libraries to identify shipwrecks as slavers. This complies with best practices in maritime archeology and investigation, but limits the methodology of recovery while it's happening. If a wreck suspected of being a slaver is identified during the course of excavation, it would provide an opportunity to revise the research plan and the preliminary questions that are asked (see James Matthews and Henrietta Marie) as well as the approach to sampling and excavtion.

The most important of all material culture discovered on the ocean floor are the ships themselves. The Atlantic Slave Trade lasted for over 300 years and ship construction evolved greatly during this period. The evolution of wooden ship construction overall is outside the scope of this study, but it did influence dynamic

\footnotetext{
${ }^{33}$ Lloyds List, Feb. $4^{\text {th }} 1803$, issue 4322.

${ }^{34}$ The Belfast News-Letter, Tuesday, April $8^{\text {th }} 1834$, issue 10102.

${ }^{35}$ Nigel Sadler, "The Trouvadore Project: The Legacy of a Sunken Slave Ship," The African Diaspora Archaeology Network. 1:27 (2007). http://www. diaspora. illinois. edu/news0907/news0907-1. pdf.
} 
changes that vessels underwent during this period. For the purpose of this study, ships will be grouped and delineated into three periods of construction. Grouping ships by period, rather than by year, country of origin, or builder allows for a loose set of confines to determine what group a ship falls into. The two main considerations determine which group a ship falls into. The first is where a ship falls in the overall time line of the slave trade, early trade, height of the trade, or after the trade is outlawed. The second factor is where the ship falls in the overall distribution of voyages, whether early, at the height, or after the trade became illegal. This means that the three groups ships are placed into is not determined by specific years, country of origin, or builder groupings but still form a linear pattern staring with the Portuguese slave trade in the early Sixteenth century spanning to the illegal trade in the late Nineteenth century.

Ship features essential to the success of a voyage changed over time, according to changing demands and circumstances as well as new technologies and shifting cultural practices. Some of these features are present across the 300-year time span of the African slave trade while others come into or fade out of practice. Special features unique to the needs of the slaving voyage were also adopted from other cultures and fade in and out of popularity based on needs of the time. This includes security devices, specialized cargo space, and features that could make a journey to West Africa faster and more survivable.

Security features on board slaving vessels include features that keep the crew safe from their human cargo, prevent the slaves from jumping overboard and keep the vessel safe from being taken. Size and number of guns, specifically the presences of 
swivel guns and rifles is one obvious security feature. The most prevalent security feature but also the least likely to survive the archeological record is the partition or barricade. A barricade is simply a wall construed for the portion of the journey when slaves were on board to separate the slaves when on deck from the crew. It also served as a defensible position in the event of an uprising. ${ }^{36}$

Below deck, bulkheads were created to separate men, woman and children. This was to prevent undesired encounters sexual or otherwise, but also to prevent insurrection. Woman and children had freer roam of the ship than men, often leading woman to play a large part in mutinies. Woman and children could find out where arms were stored and formulate ways to access that area. ${ }^{37}$ Bulkheads also allowed for more systematic loading and unloading of cargo. Loading and unloading occurred both at port and at sea as the ability to "exercise" or "dance" one group of captives on deck at a time was crucial to survival and security.

Also unlikely to survive in the archeological record is the netting around ships that keep slaves from jumping overboard. This netting is often depicted in images of slave ships and in writings by sailors (see Figure 6.7). In the outfitting of a ship extra firearms, shackles and chains, hatch covers and lattices would have been acquired, to be used for the safety and security of the crew and cargo.

Features designed to keep slaves alive included below deck structures and above deck structures. Below deck features included planking for sleeping, and quarters for the separation of men, woman, children, and the crew. Additional port

\footnotetext{
${ }^{36}$ William Duane, The Mariners Dictionary or American Seaman's Vocabulary of technical terms and Sea phrases, used in the Construction, equipment, Management, and Military Operations of ships and vessels of all descriptions (Washington City, 1805), 14.

${ }^{37}$ Leo Balai, Slave Ship Leusden: A story of Mutiny, Shipwreck, and Murder. (Norwich, UK:UTS publishing, 2013), Kindle Edition, Location 1055.
} 
holes for air circulation were also an important below deck feature to keep slaves alive. Above the deck, special sails made slavers distinguishable by sight. These sails were used to push air below deck and increase air circulation. The before mentioned netting was put into place as a method to decrease suicide and would also fall under this category. Above deck would also be a space designated for a large slave stove. These brick stoves would be used to cook the mass quantities of slave food (rice and beans mostly) needed to daily to feed the cargo. Below deck the storage of water casks, separate from the slaves and there excrement insures the survival of all aboard.

Unlike features related to security and mortality, the configuration of cargo space was more dependent on region and period. Cargo space available depended first on the legality of the slave trade, with more cargo space associated with ships when the trade was legal. The number of decks and tonnage varied depending on the merchant and the country of origin. Speed was influenced by the same factors as cargo space and could also be affected by the number of decks, number of sails, tonnage, angle of the stern post, and angle of the stem post. The speed of ships also varied depending on the legality of the slave trade, and the amount of time illegal vessels were willing to stay on the African coast. Finally, this category also includes features related to decoration on the outside of the vessel and the painting or lack thereof.

The 300 years of the Atlantic slave trade can be sub-divided into three groups or periods. The first period is that of early traders. The least amount of evidence exists to support the hypothesis that slave ships during this period were specially built. However, twenty percent of the total numbers of slaves to leave Africa were taken during this phase. The first Africans brought to the new world arrived at the beginning 
of the sixteenth century. The first voyages with slaves on board were not dedicated solely to the trafficking of people. Instead, they carried a mixed cargo. Ships supported new and growing colonies that were not yet self-sufficient and trade routes that were not yet totally established, this changed as the need for labor increased. The first voyage to go directly from Africa to the new world most likely sailed in $1526 .{ }^{38}$

Initially, ships used to trade with Africa varied, merchants used whatever ship was available to them with little to no regard to design, if the ship could make the voyage then it was considered worthy. "John Hawkins, the first Englishman to make a slaving voyage, sailed to the Guinea coast for the first time in 1562 with three ships that could carry loads of 120,100, and 40 tons. When he returned from a second voyage, his fleet included the Ages, [and] former naval vessel Jesus of Lubeck, which displaced 700 tons. ${ }^{{ }^{39}}$ Neither of these vessels where ships that had originally departed on the journey and none of the vessels used in this initial voyage was specially built for the trade.

\footnotetext{
${ }^{38}$ David Eltis, "Early Slaving Voyages: A Brief Overview of the Trans-Atlantic Slave Trade," (Emory University, 2007). Accessed Jan 2014. http://www.slavevoyages.org/tast/assessment/essays-intro04.faces

${ }^{39}$ Junius P. Rodriguez, "Shipbuilding," The Historical Encyclopedia of World Slavery Volume 1-7 (Santa Barbara, Ca: ABC-CLIO, 1997), 583.
} 
The sixteenth-century

transatlantic slave trade was

dominated by Iberian craft like

the caravel and the naos. Noas,

a generic term for a large

round sailing ship, had

characteristics that included a

square sail on the main and

foremast, lateen sail on the

mizzen mast, and large fore

and stern castles (Figure 3.1). ${ }^{40}$

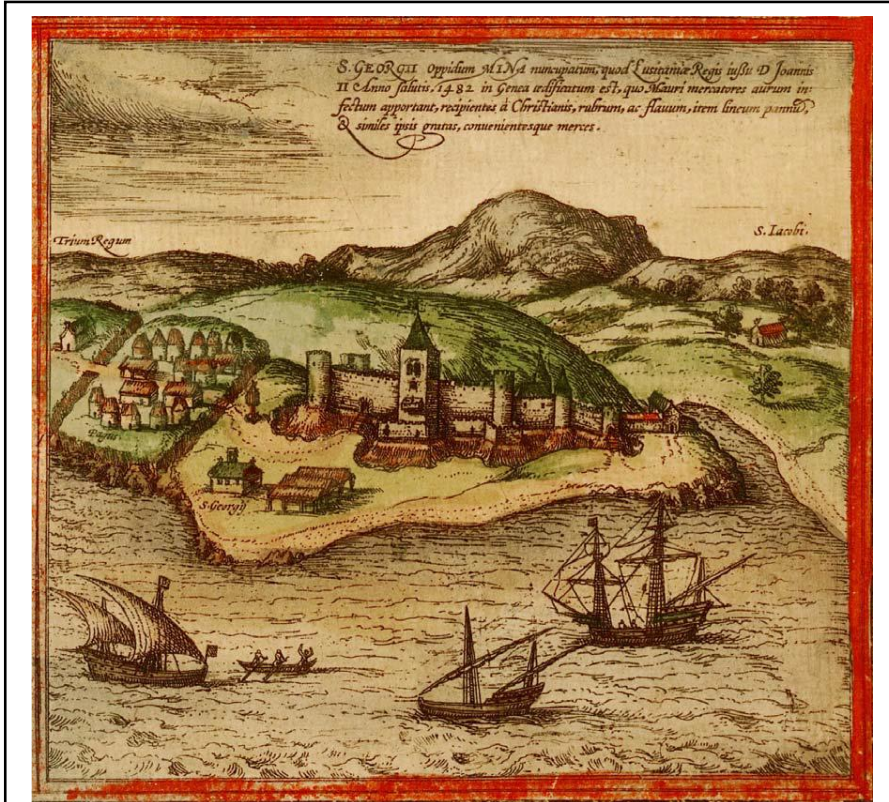

Figure 3.1: Georg Braun Franz Hogenberg, and John Goss. Elmina, Print, in The City Maps of Europe: $16^{\text {th }}$ Century town Plans from Braun \& Hogenberg, (Chicago: Rand McNally, 1992).

The development of a multi-mast, full-rigged ship with mounted a stern rudder, was a consequence of the revolution in shipbuilding technology during the Renaissance. ${ }^{41}$

Navigation of the African coast and the Atlantic became possible as a result of these innovations. The ships used in these early voyages of "discovery," called caravels, were the first vessels to transport African slaves to the New World. Except that it was a tiny vessel with a composite rig of square and lateen sails, little is known about the actual construction of the caravel. Seen in Figure 3.1; the characteristics include lack of a forecastle, low stern castle, and multiple masts. ${ }^{42}$

The first mainland Spanish American intended destination for a slave vessel was Cartagena in modern day Columbia, beginning in 1549. Before this, all ships

\footnotetext{
${ }^{40}$ Greg Cook, "The Maritime Archaeology of West Africa in the Atlantic World: Investigations at Elmina, Ghana," (Dissertation, Syracuse University, 2012), 76.

${ }^{41}$ Ibid., 78.

${ }^{42}$ Robert Smith, Vanguard of Empire: Ships of Exploration in the Age of Columbus. (New York: Oxford University Press, 1993), 239.
} 
carrying captives from Africa sold their slaves in the Spanish Caribbean. The gold mines of Cibao, Hispaniola (modern day Dominic Republic and Haiti) needing a constant supply of labor, was the largest purchaser. The great majority of the captives came from the Upper Guinea coast, moving through Portuguese factories in Arguin (modern day Mauritania coast) and later Cape Verde Islands (450 miles of the coast of Senegal). By 1526, slaves, originating in the Congo were leaving Portuguese factories in the Bight of Biafra.

Sugar drove traffic to Brazil beginning in 1560; forty percent of the trade would eventually go to Brazil. By 1630, most of the sugar consumed in Europe came from Brazil, and almost all of the slaves producing that sugar came originally from Africa. As sugar consumption grew, two major branches of the slave trade were established, one going to Brazil, and the other to mainland North America.

The trade during this early period steadily increased as not just sugar grew, but new gold mines and additional new world resources were discovered. This increase also opened the African continent; more slaves came from more places, opening up the coast. An estimated 30,000 people were enslaved each year in the 1690 s. This number would reach 85,000 annually by 1790 .

The Elmina wreck is the only wreck with archeological data that comes from this period. Based on wood samples taken from the site, there is 95 percent probability that the ship sank between 1642 and $1664 .{ }^{43}$ It is likely the remains of the Dutch West India Company ship the Greoningen, which sank in 1647 after catching fire when a

\footnotetext{
${ }^{43}$ Greg Cook, "The Maritime Archaeology of West Africa in the Atlantic World: Investigations at Elmina, Ghana,” (Dissertation, Syracuse University, 2012), 251.
} 
cannon exploded in salute soon after its arrival on the coast. ${ }^{44}$ The Elmina Wreck represents the pristine archaeological remains of a trading vessel that has remained undisturbed by modern salvage or looting, with exposed cannon, stacks of nested basins, casks of manillas and other trade goods in their original stowage contexts as trade cargo. However, there are clearly mixed contexts in terms of the artifact assemblage preserved on the site, with date ranges spanning the entire contact period. $^{45}$

The second period covers the height of the slave trade, roughly 1700 until the abolition of the slave trade by the English and the United States in 1807. During this period roughly fifty percent of the total number of Africans that would leave Africa was taken. Dominated by the Portuguese and the British, most of the ships in the archeological record are from this phase as well as many of the published schematics. These two nations supplied themselves with slaves, but also supplied foreign colonies and plantations with slaves causing their ships to travel the world over. More than seven out of every ten slaves went to Brazilian or British colonies. French America imported about half the number of slaves that the British did, with the majority going to Saint-Domingue. ${ }^{46}$ During this period, all European Nations with colonies attempted to supply their plantations' needs with slave labor, which were in more demand than food stuffs.

Of the ships purposely constructed for the slave trade, the highest percentages are constructed during this period. As the trade steadily increased so did the size of the

\footnotetext{
${ }^{44}$ Ibid., 257.

${ }^{45}$ Ibid., 221.

${ }^{46}$ Voyages Database. Voyages: The Trans-Atlantic Slave trade Database. Accessed Jan 2014, http://www.slavevoyages.org
} 
ships and the number of slaves imported. The need for inventive solutions to decrease mortality rates onboard these vessels, both for the slaves and the crew also increased, though the crew seemed to be less important to most merchants, as they could be replaced more readily than the captive cargo. ${ }^{47}$

During this middle period, slave ship construction expanded exponentially in both England and America. While, there may have been more ships built and therefore more ships in the archeological record, the American war for Independence temporarily halted the pace of construction. This halt in construction and the practice of both the Royal British Navy and the American revolutionaries commandeering any seaworthy vessel, dramatically decreased the number of ships in the trade and, therefore, their presence in the archaeological record. Desirable for their speed, tonnage, and readymade ability to carry weapons, it is not surprising that slave ships where often commandeered. As one merhcant noted, "His last captaincy at Lancaster was aboard the newly built Alithea, which completed a voyage to Serra Leone and Grenada just before the outbreak of war in 1776." ${ }^{48}$ After which the ship was commendered.

\footnotetext{
${ }^{47}$ Simon Hogerzeil and David Richardson, "Slave purchasing Strategies and Shipboard Mortality: Dayto-Day Evidence from the Dutch African Trade, 1751-1797," The Journal of Economic History 67:1 (2007): 160-190

${ }^{48}$ Melinda Elder, "Liverpool's Slave Trade, Lancaster and its Environments," Liverpool and Transatlantic Slavery (Edinburgh: Edinburgh University Press, 1992), 122.
} 


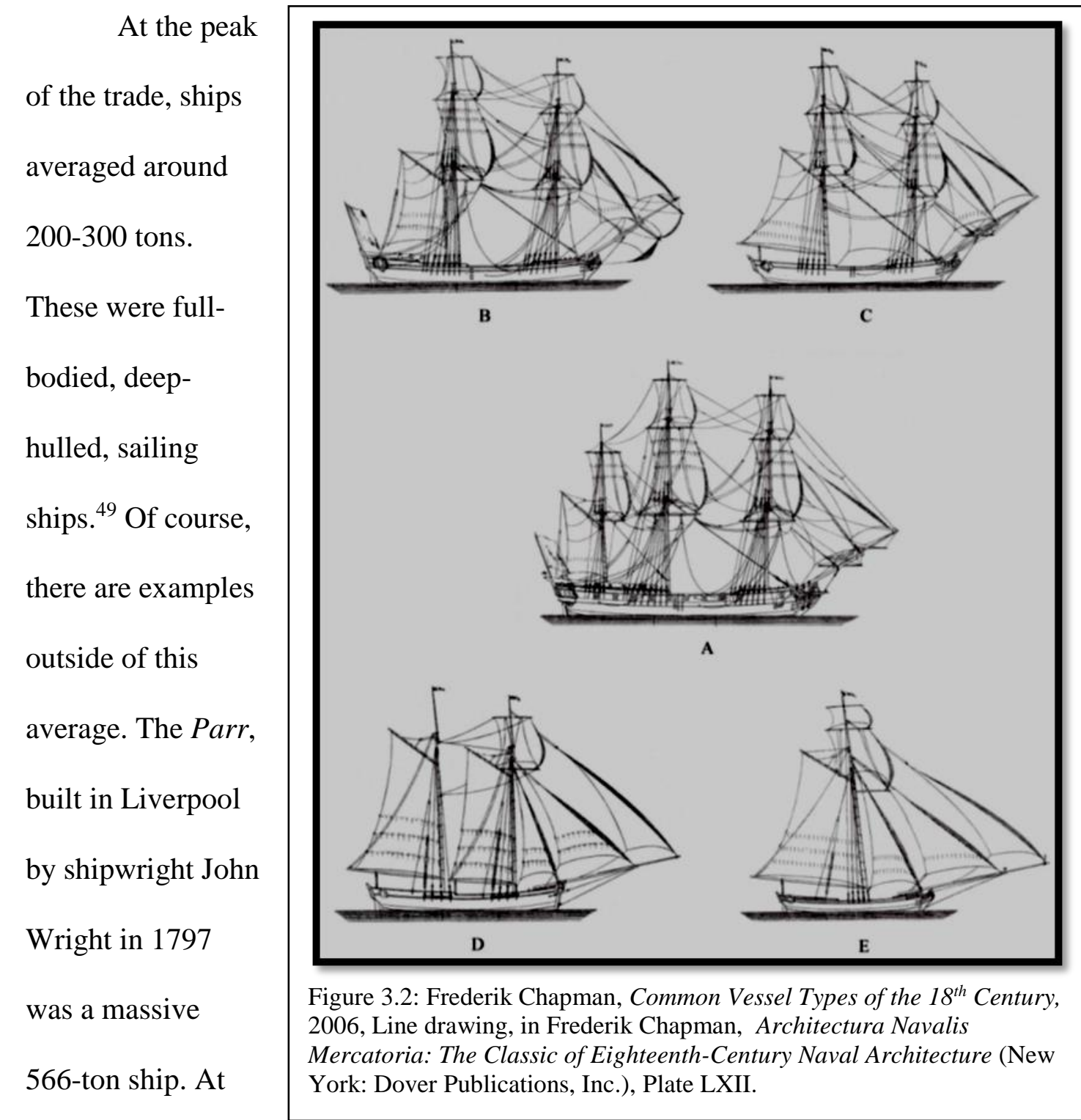

127 feet long and 32 feet in the beam, she was a three-mast, square-stern, double-

decked ship. Built to carry 700 slaves, she was also heavily armed with 20 eighteen-

pound guns and 12 eighteen-pound carronades. The Parr only sailed one voyage, after

taking 200 slaves on board at Bonny, on the Bight of Biafra, she mystery exploded. ${ }^{50}$

On the other end of the spectrum, were ships like the Adventure and the Sally. Both

\footnotetext{
${ }^{49}$ Junius P. Rodriguez, "Ships," The Historical Encyclopedia of World Slavery Volume 1-7 (Santa Barbara: ABC-CLIO, 1997), 582.

${ }^{50}$ Marcus Rediker, The Slave Ship A Human History (New York: Penguin, 2007), 63.
} 
vessels were a mere 11 tons and made voyages from Rhode Island to Africa In 1764 and 1770 respectively. ${ }^{51}$

The variety of ships used during this period was large. While the caravel may have dominated the sixteenth century, the seventeenth and eighteenth centuries were characterized by many different types of slave ships. What makes a slave ship unique, where it's on deck and below deck features, not necessarily the type of vessel. A ship is a term that can be applied to all sea going vessels but also specifically to one type of vessel. When referring to a specific vessel type, "ship" means a vessel with three masts (Figure 3.2, A). Each of these three masts is composed of a lower mast, top mast, and top-gallant mast. A "snow" (Figure 3.2, B) is a vessel equipped with two masts, a main and a fore-mast; it also has a third small mast behind the main mast similar to a ship's mizzen mast. ${ }^{52}$ A "brig" or "brigantine" (Figure 3.2, C) is a vessel with two masts, the main and fore-mast. The main-mast hangs in the direction of the keel, instead of being fastened to the main-yard and hanging at right angles to the ships keel. ${ }^{53}$ There is a slight difference between a brig and a brigantine in some classifications, attributing a brig with square sails and a brigantine with a fore and aft rig on the aftermost sail. A "schooner" (Figure 3.2, D) is a small vessel with two masts, both fore-and-aft sails suspended by gaffs, similar to a sloops main sail. However, on a schooner both the main-sail and the fore-sail are hung this way. ${ }^{54}$ Finally a "sloop" (Figure 3.2, E) is a small fore-and-aft rigged vessel with a single

\footnotetext{
${ }^{51}$ Voyages Database, STDB \#90950, 3777, 4405, 36299, 36406. The Trans-Atlantic Slave Trade Database. (Emory University, 2009). Accessed June 2013. http://www.slavevoyages.org/tast/database/search.faces

${ }^{52}$ William Falconer, A Universal Dictionary of the Marine (London: T. Cadell, 1780), 205.

${ }^{53}$ Ibid., 30.

${ }^{54}$ Ibid., 190.
} 
mast attached to a gaff above and a boom below. The sails are generally in proportion to the ship and not too large. ${ }^{55}$

Slave ships of the late-seventeenth and eighteenth centuries could be built for and exploited by the slave trade. ${ }^{56}$ "The shipbuilders of Liverpool began to custom build slave ships around 1750." ${ }^{\circ 7}$ Slave ships continued to be designed and launched right up to the moment of abolition. At that point, those still under construction were repurposed. ${ }^{58}$ Ships were specifically fitted out for the conduct of the trade: deck hatches were smaller than on standard merchantmen, the galley apparatus was more extensive to meet the needs of the cargo, and many ships had separate compartments for the stowage of males and females. ${ }^{59}$

The holds of slave ships were intensely crowded with rough pallets fitted between decks so that slaves were stacked one atop another. ${ }^{60}$ Despite this, a vessel of almost any size could be used as a slave ship. ${ }^{61}$ Ships being repurposed for the trade had decks added so that the provisions and cargo could be separate, and more room was designated for the slaves themselves. ${ }^{62}$

Slavers were well armed vessels, fitted with several cannon to defend against interlopers and pirates, and antipersonnel weapons and deck arms that could be and

\footnotetext{
${ }^{55}$ Ibid., 204.

${ }^{56}$ Junius P. Rodriguez, "Ships" The Historical Encyclopedia of World Slavery Volume 1-7 (Santa Barbara, Ca: ABC-CLIO, 1997), 582.

${ }^{57}$ Marcus Rediker, The Slave Ship A Human History (New York: Penguin, 2007), 53.

${ }^{58}$ Ibid., 54.

${ }^{59}$ Junius P. Rodriguez, "Ships" The Historical Encyclopedia of World Slavery Volume 1-7 (Santa Barbara, Ca: ABC-CLIO, 1997), 582.

${ }^{60}$ Ibid., 583.

${ }^{61}$ Marcus Rediker, The Slave Ship A Human History. (New York: Penguin, 2007), 6.

${ }^{62}$ Arron Lopez to Richard Thomas, 7 September 1763, Letter regarding the building of the Sally, Box 52, Folder 4, Sheet 52-141, Arron Lopez Papers, the Newport Historical Society Library, Newport Historical Society, Newport, Rhode Island.
} 
were used as a final means of cargo control aboard ship. ${ }^{63}$ In records relating to the outfitting of these ships, it is not uncommon for a special note to be present related to the acquisition of swivel guns and other small arms. Specifically, that the captain should obtain what he sees fit to defend the vessel both from intruders and potential uprisings. $^{64}$

Traditionally, the ribs or frame sets of merchant ships consisted of two sets of heavy timbers pegged together as they rose from the keel to the upper deck. ${ }^{65}$ The space between these double frames was equal to the width of the timbers. This method consumed much wood and labor but produced a stout hull able to carry any cargo and withstand the pounding of huge waves. But a slave vessel carried far less weight than a merchant ship of the same size. A cargo of 200 slaves would weigh no more than 14 tons. Food for the slaves would not amount to much weight (about 9 tons), but drinking water needs could add up to 10 tons. ${ }^{66}$ A crew of 25 men, with larger rations than those given to the slaves, would add 9 tons to the weight aboard the vessel. ${ }^{67}$ In order to carry a burden less than half that of an ordinary merchant ship, the slaver had no need of heavy frames spaced close together. ${ }^{68}$

\footnotetext{
${ }^{63}$ Junius P. Rodriguez. "Ships" The Historical Encyclopedia of World Slavery Volume 1-7. Santa Barbra, Ca: ABC-CLIO, 1997. 582.

${ }^{64}$ Capt. Peleg Clarke \& Fletcher, 6 February 1772, memoir of agreement for sale of a new Brig, Box 52, Folder 4, Sheet 52-187, Arron Lopez Papers, the Newport Historical Society Library, Newport Historical Society, Newport, Rhode Island.

${ }^{65}$ Junius P. Rodriguez, "Ships" The Historical Encyclopedia of World Slavery Volume 1-7 (Santa Barbara, Ca: ABC-CLIO, 1997), 582.

${ }^{66}$ Ibid., 583.

${ }^{67}$ Ibid., 582.

${ }^{68} \mathrm{Ibid} ., 582$.
} 
Builders

experimented with

widely spaced

double frames and

alternation double

and single frame

sets. The gap

between the

timbers was

greater, resulting

in a lighter vessel

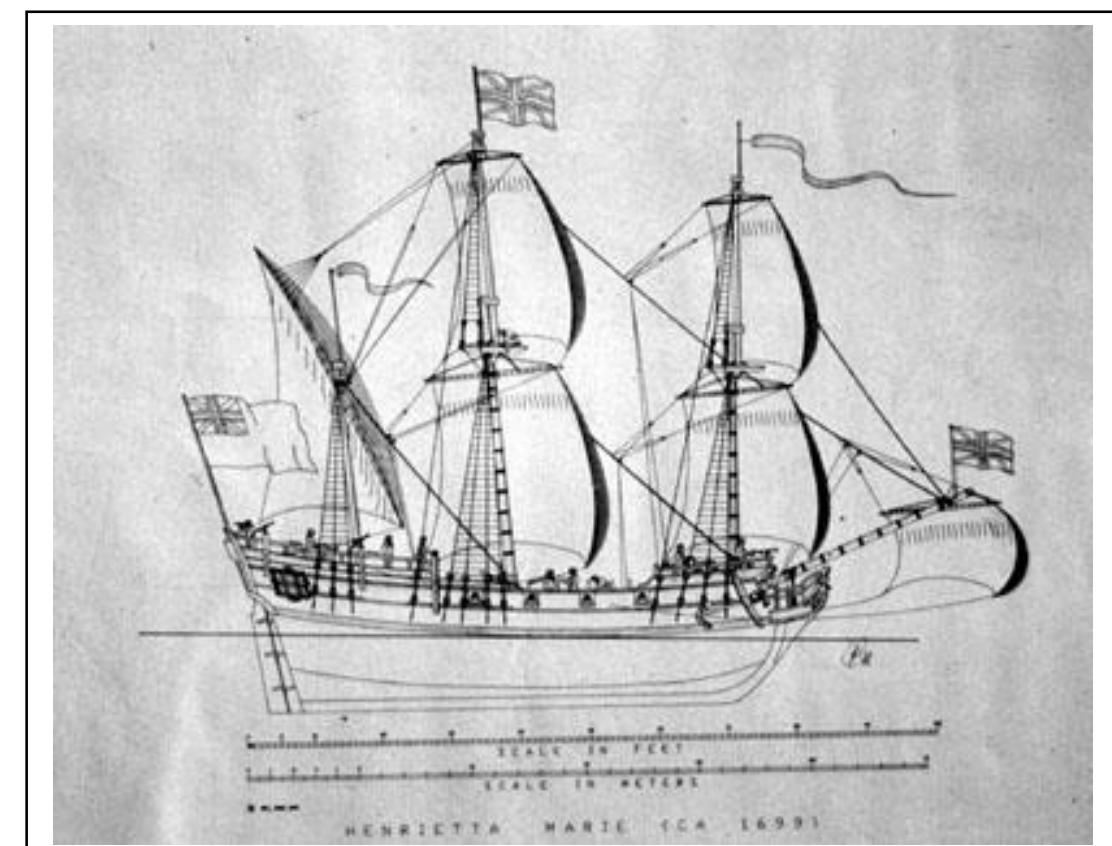

Figure 3.3: The Henrietta Marie, 1997, Line Drawing, in David Moore, "Site Report: Historical and Archaeological Investigation of the Shipwreck Henrietta Marie.” (Mel Fisher Maritime Heritage Society, 1997).

that required less timber to construct. ${ }^{69}$ It might also be faster. This could be found in the archaeological record, unfortunately none of the ships excavated thus far have examined the timber structure for these types of modifications.

The Henrietta Marie was an English vessel of approximately 120 tons and 80 feet long. ${ }^{70}$ It is one of the few slave ships to have been archeologically examined, though it still sustained heavy damage after a treasure hunting enterprise discovered it. She was returning to London in the summer of 1700 when she wrecked off the coast of KeyWest, FL. ${ }^{71}$ Even having been archeologically examined, the research yielded little about the actual hull itself. The focus of research was centered on the material recovered though it could be argued that the largest artifact that the investigator had

\footnotetext{
${ }^{69}$ Ibid., 583.

${ }^{70}$ Corey Malcom, "The reexamination of the hull of the Henrietta Marie," Mel Fisher Maritime Heritage Society, Key West. (2001), 3.

${ }^{71}$ Ibid., 3 .
} 
access to was the hull. This artist rendering of the ship (Figure 3.3) does not demonstrate any of the features that would suggest this ship was a slaving vessel. In fact, the reason that she was identified as a possible slaver was the discovery of shackles and chains while the company who discovered her was looking for gold.

The French frigate Adelaide, weighing 400 tons left France from the port of Lorient in Brittany for Guinea in 1714. After disembarking the slaves acquired in Guinea, some 360, at Leogane, Haiti a hurricane caught the ship. On Oct. $10^{\text {th }} 1714$ off the coast of Cuba, she ran into a reef and sank within an hour. She broke into two parts. The bow washed ashore, and the stern sank, resulting in 106 causalities. The material discovered at the site includes two anchors, parts of the ships rigging, ceramics, navigation instruments, and objects of daily life. ${ }^{72}$ Though, no official reports or article have come out related to this wreck.

${ }^{72}$ Franck Giddo, “Adelaide,” Others: Franck Giddo Underwater Archaeologist. (Accessed Feb. 2013), http://www.underwaterdiscovery.org/projects/others/adelaide.html 
The Whydah was originally a slave ship that was captured and repurposed by the pirate Sam Bellamy. Bellamy utilized the Whydah as his flagship because of the traits that she had. Discovered by a group of treasure hunters, the Whydah sank off the coast of Massachusetts; her remains lie in waters that are particularly challenging to access. According to Barry Clifford, who discovered the wreck, there is little to no hull structure left. ${ }^{73}$ What is known about the ship's career as a slaver is what has been found in historical documents and the discovery of a few beads and shackles in the site's concretions. While more may be discovered about this vessel, until the owners allow researcher's access to their collection and historic documents all that the Whydah contributes to

the

scholarship is

the notion

that pirates

sought

slaving

vessels as part

of their fleet.

Before

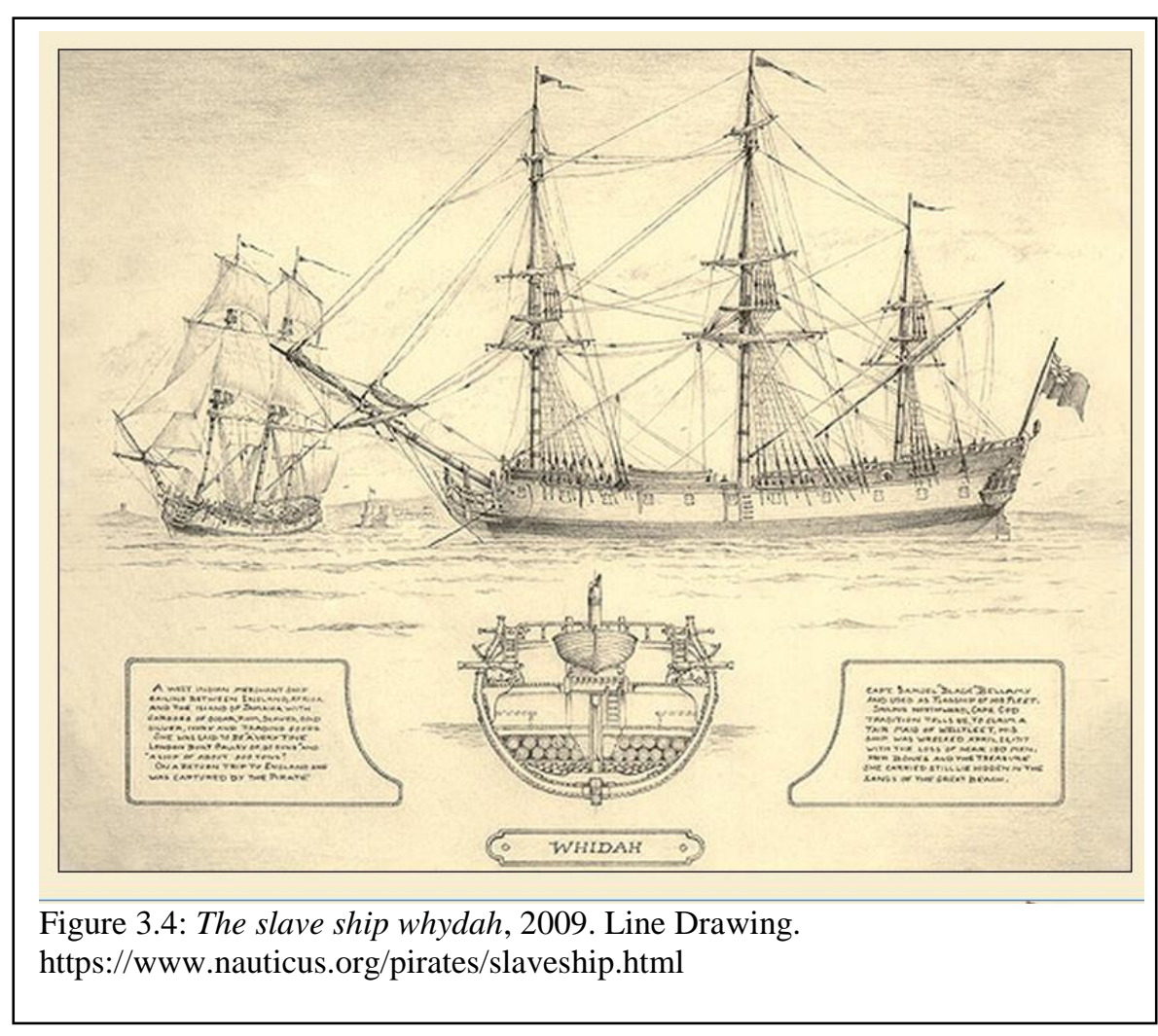

she was the

notorious pirate vessels captained by Black Beard, Queen Anns Revenge was a 250 ton

\footnotetext{
${ }^{73}$ Barry Clifford, Expedition Whydah: The Story of the World's first excavation of a pirate treasure ship and the Man who found her (New York: Harper Collins, 1999), 111.
} 
French slave ship named La Concorde ${ }^{74}$ The date and place of her construction are unknown, but she did make three slave trading voyages. The first of these was in 1713, the next in 1715 and the last in $1717 .{ }^{75}$ Despite being armed with sixteen cannons and a crew of seventy-five, she and the surviving slaves of the original 516, were captured 100 miles off from Martinique. ${ }^{76}$ Having made the long journey from the port of Judas or Whydah (present-day Benin), she succumb to the notorious pirate, only to be later run aground and abandon by the same Captain, she broke up at Beaufort Inlet, North Carolina.

The Queen Anne's Revenge

was used initially as a privateer during Queen Anne's War and then refitted for slaving. The main aspect of the refit was the addition of two rows of the half deck below the main deck. Half decks are also known as

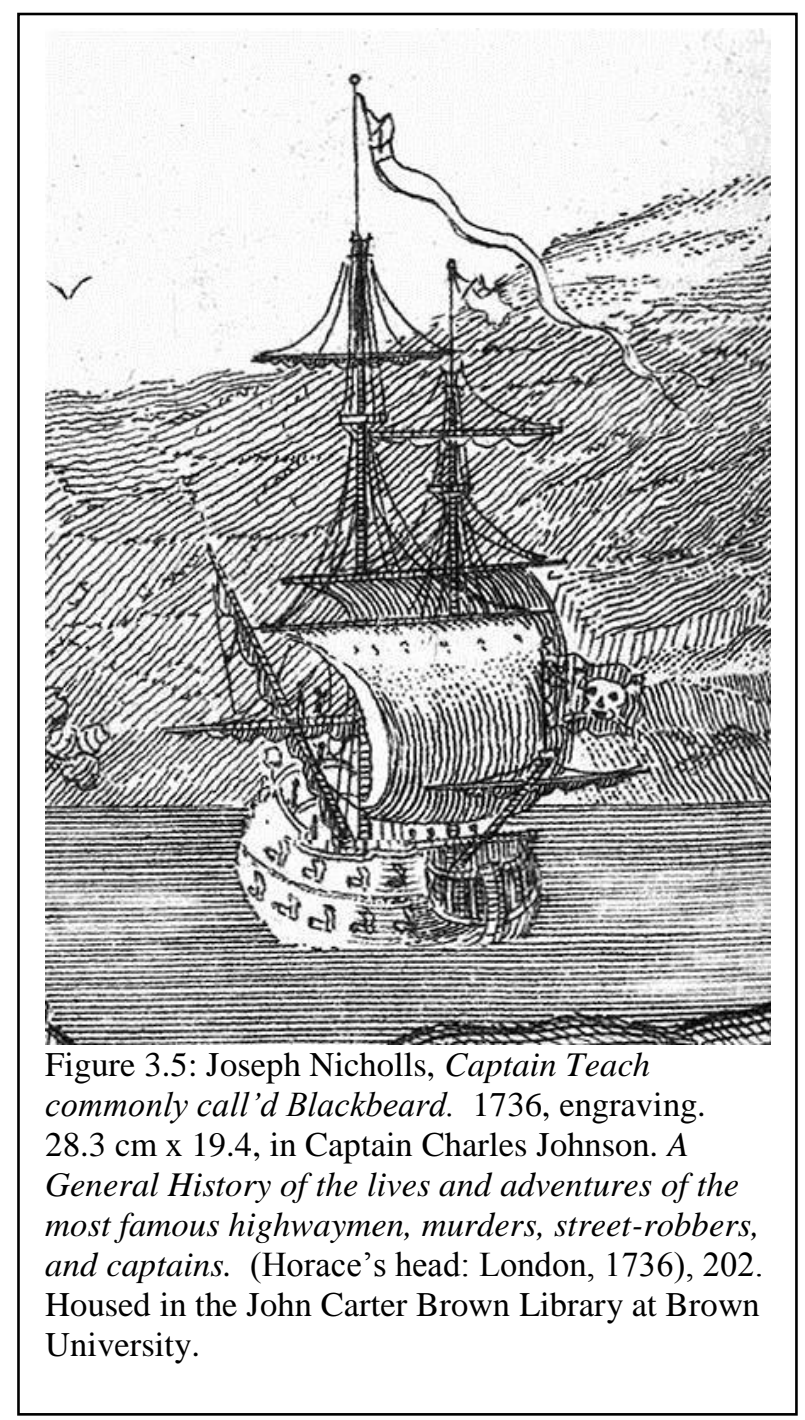
shelves. The four feet four inches of space between decks was maximized by these

\footnotetext{
${ }^{74}$ Rick Lawrence and Mark Wilde-Ramsing, "In Search of Blackbeard: Historical and Archaeological Research at Shipwreck site 003BUI," http://www.qaronline.org/History/TheShipsJourney.aspx ${ }^{75}$ Ibid., 1.

${ }^{76}$ Mark Wilde-Ramsing, "Historical background for the Queen Anne's Revenge Shipwreck Site," Queen Annes Revenge Shipwreck Project; Research report and bulletin Series QAR-R-09-02, Aug 2009. (Accessed Feb 2013).http://wayback.archive-it.org/org-

67/20120515002435/http://www.qaronline.org/techSeries/QAR-R-09-02.pdf
} 
half decks used for stowing more slaves. ${ }^{77}$ Also placed under the stern castle was the galley. The placement of the galley under the sterncastle is different from its traditional location forward of the mast. Arranging of the deck in this way allowed for convent separation of crew and cargo. This arrangement also separated access to the ship's magazine, rudder and steering accessed through the stern as opposed to through the cargo like other merchant ships. This configuration also allowed for quick and easy construction of a barricade if needed.

The Leusden was built by shipwright GerbrandSlegt, the building and outfitting of the vessel cost f.53, 094.00. ${ }^{78}$ Built in 1719 , it took nearly eight months for the 120-foot long ship to be finished. She was a frigate, measuring 111.5 feet in length, 30 feet wide, 6.2 feet tween decks and 12 feet in height. ${ }^{79}$ The Leusden had twelve guns on board, two eight pounders, four six pounders, two four pounders, and four three pounders, it also carried a small boat and towed a sloop. ${ }^{80}$ Unlike other vessels, she did have a figurehead as is apparent from the bill for a sculptor's fee. The boat on board measured a length of 26 feet and a width of 7.3 feet while the sloop measured 24 feet long and 6 feet wide. ${ }^{81}$

References by the owning company in August 1720 to build "another nine frigates into slave ships according to the specification of the ship Leusden", suggest that she did have some specialized features for the slave trade. ${ }^{82}$ Documentary evidence also suggests the Leusden underwent a mid-journey transformation. Before

\footnotetext{
${ }^{77}$ Ibid., 7.

${ }^{78}$ Leo Balai, Slave ship Leusden: A Story of Munity, Shipwreck, and Murder (Norwich: UTS

Publishing, 2014), Kindle Edition. Location 552.

${ }^{79}$ Ibid., Location 562.

${ }^{80}$ Ibid., Location 612.

${ }^{81}$ Ibid., Location 622.

${ }^{82}$ Ibid., Location 559.
} 
her first voyage, she had taken aboard 244 wooden planks. These planks were used to construct the slave quarters or half decks on board. ${ }^{83}$

Another slaver

discovered by treasure hunters is the Fredensborg. The

Fredensborg and the Leusden are often compared but contribute different knowledge to our understanding of slave ships. The three masted slave ship Fredensborg, wrecked on

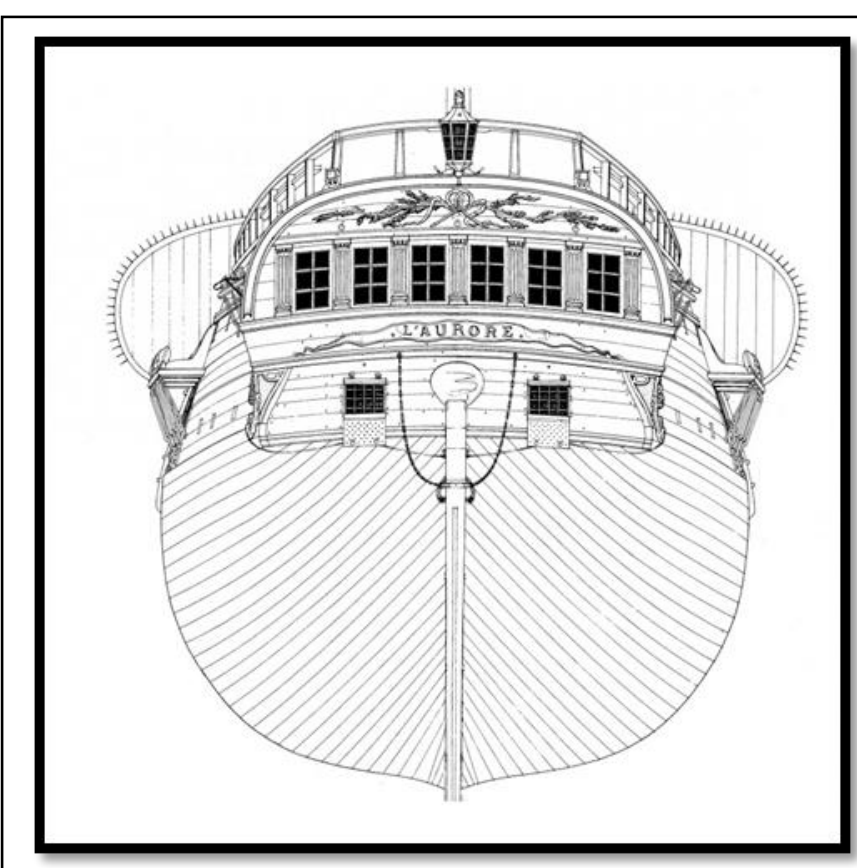

Figure 3.6: Jean Bellis, The Rear of the Slave Ship Aurora, Monograph, reproduced from Jean Boudriot, Monographie De L'Aurore- Navire negrier-1784 (Nice, France :Ancre) 95.

Dec. 1, 1768, she was completing her journey from the Caribbean after having disembarked slaves there. She sank in a storm roughly 650 feet from shore. ${ }^{84}$ The company attempted to salvage her soon after wrecking, but the location of the wreck was in water to violent for the technology available at the time.

Discovered by treasure salvors, her remains were scattered in a small cove. While little attention was paid to her structural components, the material cultural aboard provided more information. Once the site was taken over by the National Museum of Norway much of that changed and extensive research has been done on the vessel. From the historic record, much of the outfitting of the ship can be discerned. One of the more unique passages comes from a discussion between the

\footnotetext{
${ }^{83}$ Ibid., Location 773

${ }^{84}$ Leif Svalesen, The Slave Ship Fredensborg (Indianapolis: Indiana Univ. Press, 2000), 105.
} 
Captain and a colleague in which the former attempted to find a carpenter to transform the ship before it reached the African coast. This included the need to build a water closet or privy for the slaves. ${ }^{85}$

The space between decks of the Fredensborg was approximately six feet, which is much larger than its English counterparts. This area is where slave or quarter decks where erected for slaves to sleep and be stowed. ${ }^{86}$ This task again required the loan of a carpenter and so there are records that outline the process. In addition, the carpenter constructed a slave stove, with the assistance of a mason (also brought from land) and the slave or storm bulwarks. While the mason did the most of the work on the slave stove, the carpenter disassembled the gangway on the portside in order to make room for the stove. ${ }^{87}$ The carpenter also constructed the slave or storm bulwarks. These solid partitions extended from the deck well above the quarter-deck. Strong doors where placed into the bulwarks with hinges made by a local blacksmith, and mounted swivel guns placed atop. ${ }^{88}$ Unlike a barricade, these bulwarks where not solid walls but served the same purpose. Instead of using small hand arms, they had mounted guns, so pickets where not needed.

The ship L'aurore is often compared to a french slave ship National Assembly that sank in $1795 .{ }^{89}$ The sinking of National Assembly was documented in french admierlty court and gained noterity but was prepelled to further fame upon her discovery in 1994. L'aurore, who is larger than National Assembly, is similar.

\footnotetext{
${ }^{85}$ Ibid., 75.

${ }^{86}$ Ibid., 92.

${ }^{87}$ Ibid., 93.

${ }^{88}$ Leif Svalesen, The Slave Ship Fredensborg (Indianapolis: Indiana University Press, 2000), 92.

${ }^{89}$ Maritime History of Northern Britain, "The War at Sea: On September 2, 1795, the sinking of the former slaver 'national assembly' in the north of the island of Er," Accessed Feb 2013.

http://www.histoiremaritimebretagnenord.fr/activit\%C3\%A9s-maritimes/la-guerre-en-mer-1//
} 
L'aurore is not as well document in court papers but has been extnesivly illustrated by Jean Bellis. Bellis using a series of drawings of ships fro 1793 are among the most detailed and accurate in the world. ${ }^{90}$ The 1793 series of drawings where created when many ships where purchased by the french governement to fight the war with Britiain, part of the revolutionary wars. Utilizing these illustartions Bellis has been able to create some of the most accurate drawings of a slave vessel in the world.

The remains of National Assembly where discovered in 1994, first by a group of divers and later examined by a group of archaeologists. None of the hull remained and amoungst the jagged rocks some cannon and other iron objects where discovered, all indicative of the ship's life as a naval privateer. L'aurore on the other hand has been studied and shows many of the features of a slave vessel. This includes the suckers or extra port holes for air circulation. Unique is the perspective, other illustartations normally show either the port or starbord side of the ship, this shows the stern (also see Figure 3.6). ${ }^{91}$

The Enterprise is listed as a three masted, square stern ship with two decks, and was lost in Belfast in $1803 .{ }^{92}$ At a length of 93 feet to the aft part of the taffrail and 24 feet 4 inches wide below wales, she is a small to medium sized vessel. The taffrail is a railing, sometimes ornately decorated, which covers the stern of the ship in order to prevent people from falling overboard. ${ }^{93}$ The wales are the thickest line of the

\footnotetext{
${ }^{90}$ Maritime History of Northern Britain, "The War at Sea: On September 2, 1795, the sinking of the former slaver 'national assembly' in the north of the island of Er," Accessed Feb 2013. http://www.histoiremaritimebretagnenord.fr/activit\%C3\%A9s-maritimes/la-guerre-en-mer-1/ ${ }^{91}$ Maritime History of Northern Britain, "The War at Sea: On September 2, 1795, the sinking of the former slaver 'national assembly' in the north of the island of Er," Accessed Feb 2013. http://www.histoiremaritimebretagnenord.fr/activit\%C3\%A9s-maritimes/la-guerre-en-mer-1/ ${ }^{92}$ Lloyds List, February 4th 1803, Issue 4322.

${ }^{93}$ Arthur Young and James Brisbane, Nautical Dictionary (London: Longman, Green and Roberts, 1863), 301.
} 
planks that run around the outside of the ship. ${ }^{94}$ In the 1791 registry document, the figurehead of the ship is simply described as a "figure," later to be revised to "woman." This is quite different from the most frugal nature of other ships built with little to no extra design or decoration. This probably speaks to the ship-owner and his desire that his ships be recognized. The Enterprise that is discussed here is, in fact, the third ship from this specific owner with the iteration of that name. ${ }^{95}$

Described briefly in the ship's log book, the vessel underwent a mid-journey transformation that seemed to be consistent with other similar vessels. Once arriving at port in Africa, the goods were offloaded and stored in a warehouse. The Enterprise, being an English vessel, had a carpenter on her crew list. ${ }^{96}$ This carpenter then installed a series of temporary slave decks as well as the barricades on deck. ${ }^{97}$ Guns were placed along the barricade to provide additional protection. ${ }^{98}$ After unloading her cargo in the Caribbean all of these features were removed.

A Mr. Haughton of Liverpool first salvaged the wreck in 1834 using tongs that were constructed specifically to salvage dollars from the wreck. ${ }^{99}$ Tongs are similar to cranes today. Mr. Haugton used the tongs to reach down blindly and pull material up from the ocean floor. There were likely large sections of the ship that were destroyed at this time. The wreck was salvaged again in 1829 , by what could be considered treasure hunters. Using five different ships and diving bells, approximately 50,000

\footnotetext{
${ }^{94}$ Ibid., 35.

${ }^{95}$ Matt Smith, “The Artefact Biography of a Slave Shipwreck: The Enterprise,” (Master's Thesis, Barton College, 2010), 85.

${ }^{96}$ Ibid., 75.

${ }^{97}$ H. Klein, The Atlantic Slave Trade (Cambridge: Cambridge University Press, 2010), 134-135.

${ }^{98}$ B. Mouser, A Slaving Voyage to Africa and America (Bloomington: Indiana University Press, 2002), 63.

${ }^{99}$ G. Reid, Marine Salvage (New York: Sheridan House Inc., 1996), 51.
} 
dollars were recovered. ${ }^{100}$ The dollars referred to here are Spanish dollars, better known as pieces of 8 and were used as a standard coin from the late 1400s onward, as they held their value well. ${ }^{101}$ While is unlikely, due to conflicting reports from the time, there could have been other goods that had been loaded on board the Enterprise in Cuba that were uncovered at this time and discarded. ${ }^{102}$ John Deane and his brother, using the mobile diving suit that they had invented were the only of the salvagers in 1834 to ask for permissions from the Admiralty Board to investigate the wreck. ${ }^{103}$ The brothers also had the most success and became wealthy from the profits they were able to make salvaging the ship. ${ }^{104}$ Sports divers rediscovered the Enterprise in the early 1990s. The divers dove at the site several times, but the only documentation that remains is a single sonar image; analysis of that image suggests the ship has minimal chances of long term preservation. ${ }^{105}$

The third and last period of slave ship construction comprises ships sailing after 1807. After this date, the slave trade was illegal in England. It was during this period that the British Navy started patrolling the coast of Africa in an attempt to interdict slavers. It is not until 1834 , that slavery was fully outlawed in the British Empire and not until 1863 that slavery was outlawed in the United States. In Brazil,

\footnotetext{
${ }^{100}$ Matt Smith, "The Artefact Biography of a Slave Shipwreck: The Enterprise," (Master's Thesis, Barton College, 2010), 85.

${ }^{101}$ S. Pond, "The Spanish Dollar: The World's Most Famous Silver Coin," Bulletin of the Business Historical Society 15(1941): 12.

${ }^{102}$ Matt Smith, "The Artefact Biography of a Slave Shipwreck: The Enterprise," (Master's Thesis, Barton College, 2010), 86.

${ }^{103}$ J. Bevan, The Infernal Diver: The Lives of Jon and Charles Deane, their Invention of the Diving Helmet, and its First Applications to Salvage, Treasure Hunting, Civil Engineering and Military Uses (London: Submex, 1997), 70.

${ }^{104}$ J. Bevan, The Infernal Diver: The Lives of Jon and Charles Deane, their Invention of the Diving Helmet, and its First Applications to Salvage, Treasure Hunting, Civil Engineering and Military Uses. (London: Submex, 1997), 97.

${ }^{105}$ Matt Smith, "The Artefact Biography of a Slave Shipwreck: The Enterprise," (Master's Thesis, Barton College, 2010), 91.
} 
the slave trade was not banned until 1850, and it was not until 1888 that the slavery is banned altogether, and slaves emancipated.

Although in 1807, the slave trade was banned in Britain and the United States, other European countries, specifically Spain and Portugal, delayed prohibition of the slave trade and only weakly enforced laws that were passed limiting it. Despite efforts to redirect merchants to other trades, in Nigeria merchants where encouraged to trade palm oil instead of slaves, the slave trade persisted. ${ }^{106}$ This prompted the establishment of the anti-slavery squadron, a detachment formed by the British Royal Navy to chase down all ships carrying enslaved Africans. ${ }^{107}$ Captured ships were seized and condemned. The anti-slavery squadron was active between 1811 and the 1880s and captured 1600 ships, freeing over 150,000 Africans. ${ }^{108}$ In addition to those ships captured by the British Royal Navy, vessels suffered the vagaries of the sea and sank, many times while taking risks to avoid British naval vessels. ${ }^{109}$ These factors led to rapid and dramatic changes in ship design and construction. ${ }^{110}$

Vessels sailing during this period were lighter and faster than their

predecessors. A few steamships were even the introduction to transport slaves across the Atlantic. ${ }^{111}$ Because the slave trade at this time was prohibited there are few merchant documents related to the ships themselves. This renders information to be

\footnotetext{
${ }^{106}$ The anchorage off the Town of Bonny River sixteen miles from the Entrance, Water Color with Graphite painting, 200mm x 370mm, National Maritime Museum, Greenwich, London. http://collections.rmg.co.uk/collections/objects/106080.html

${ }^{107}$ Nigel Sadler, "The Trouvadore Project: The Legacy of a Sunken Slave Ship," The African Diaspora Archaeology Network. 1:27 (2007): 2

${ }^{108}$ Howard Johnson, "The Liberated Africans, 1811-1860," in The Bahamas in Slavery and Freedom (Kingston, Jamaica: Ian Randle Publishers, 1991), 31.

${ }^{109}$ Nigel Sadler, "The Trouvadore Project: The Legacy of a Sunken Slave Ship," The African Diaspora Archaeology Network 1:27 (2007): 2.

${ }^{110}$ Junius P. Rodriguez, "Shipbuilding" The Historical Encyclopedia of World Slavery Volume 1-7 (Santa Barbara: ABC-CLIO, 1997).

${ }^{111}$ Herbert S. Klein, The Atlantic Slave Trade (Cambridge: Cambridge University Press, 1999), 201.
} 
taken from accounts of the British Navy, Art, and the archaeological record as particularly important.. Because of the navy's involvement and the habit of newspapers and others recounting the capture of illegal slave ships, there are a disproportionately high number of images from this period.

Slaving, after 1807, became extremely profitable. The majority of vessels were operating as smugglers, especially in the eyes of the British, who had a substantial command of the sea. Now operating as smugglers, slavers adopted the swift hull form of the Baltimore clippers. The Baltimore clipper appeared just after the revolutionary war. It was designed for speed both with and against the wind. The Baltimore clipper was ideal for the illegal trade, with a long slim hull and exceptionally large spread of sail on three masts. Baltimore clippers had a heart shaped midsection with short keels and raking sterns. The hulls were low-sided and sharped bowed with a minimum freeboard. These ships bore no figureheads, headboard or trail boards. The ships mast was further aft on the ship and taller, allowing more efficient use of sails. ${ }^{112}$ These vessels sacrificed substantial hold space in comparison to the European ships that had been used in the trade in the lateeighteenth century, but the rise in prices for new slaves made the trade so lucrative that ships could be built for a single voyage and destroyed upon its completion and still turn a profit on the entire venture.

Several shipbuilders from the Cheesapeke Bay area in the Unites States relocated to Havana and Bermuda during the depression in shipbuilding that came after the war of 1812. When that depression ended, these shipbuilders began to

${ }^{112}$ Eric Jay Dolin, When America First Met China: An Exotic History of Tea, Drugs, and Money in the Age of Sail (New York: Liveright Publishing Corporation, 2013), 268. 
produce ships that were specifically designed for slaving — better-balancing hold space and speed. These ships typically had straight sheers with no upper works or pronounced superstructure, which gave them a sleek appearance. Slavers flew a great deal of sail in order to maximize their speed, usually favoring a big rig. The holds of these shallow-draft ships were swept, and single-decked, with slaves, often lying on woven mats placed on top of the casks that held the ships stores. ${ }^{113}$

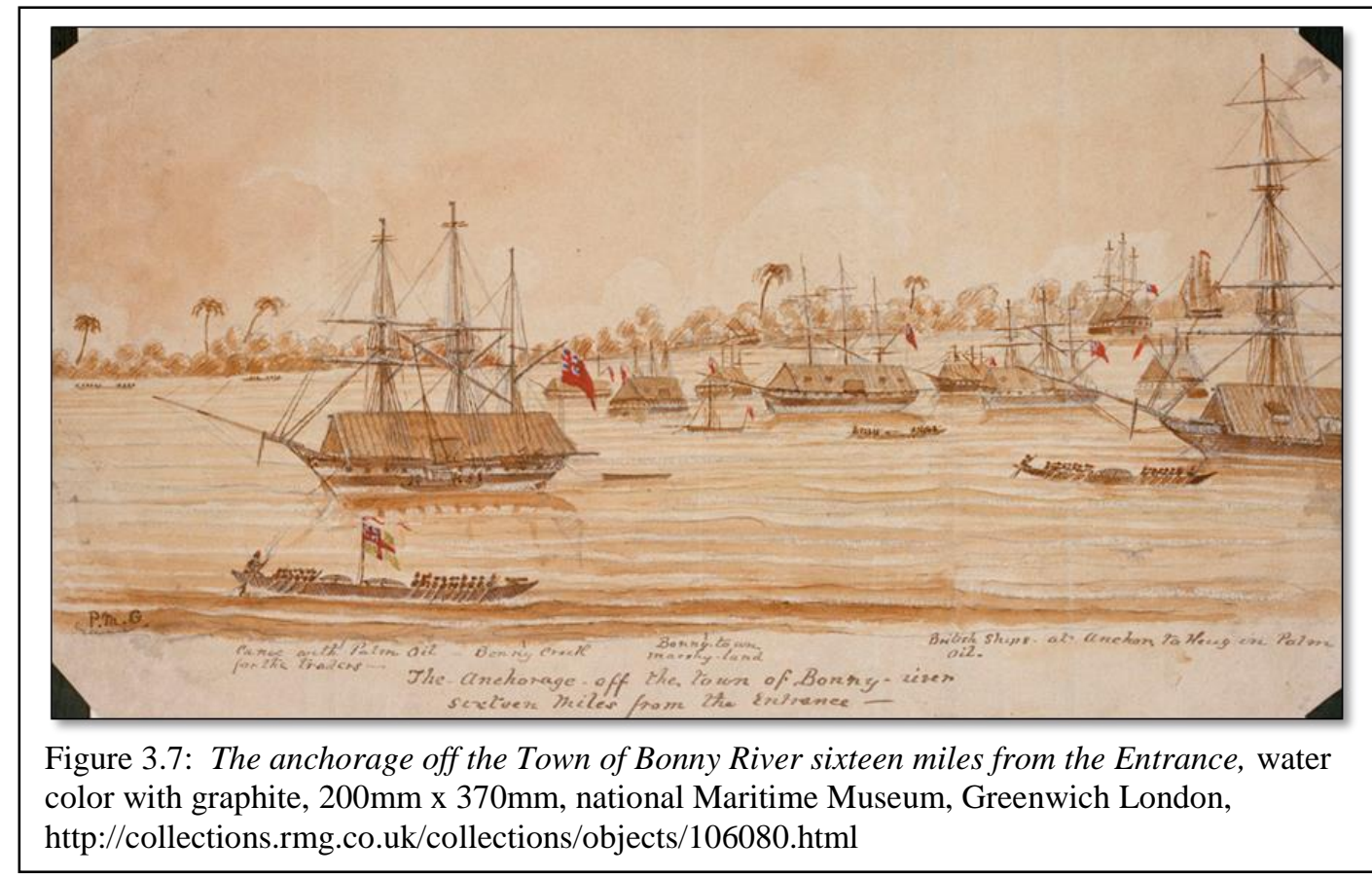

Some features remained the same. The use of awnings, like those pictured in "The anchorage off the Town of Bonny River 16 miles from the entrance," (Figure 3.7) were still in use well into the mid-1840s. Features like awnings, that address problems that persisted, like heat, remained. This watercolor in particularly, shows that Portuguese dealers in the 1820s and 1830s where still anchoring of the coast of

\footnotetext{
${ }^{113}$ Junius P. Rodriguez, "Ships," The Historical Encyclopedia of World Slavery Volume 1-7 (Santa Barbara: ABC-CLIO, 1997).
} 
Nigeria to access the some 30,000 slaves per year that the Bonny king provided. ${ }^{114}$

These features did not interfere with the need to make vessels lighter and speedier.

Another way of saving weight and reducing construction costs was to eliminate the lower deck, similar to the vessel pictured in Figure 3.8. The hull thus became an open area with slaves placed on mats that covered the barrels of water and provisions directly beneath them. This system reduced the number of slaves a vessel could carry. Slaves and their provisions were loaded in a much shorter time, and the reduction in loading time on the African coast was important to slavers since that was the period they were most vulnerable to British warships.

Construction costs were further reduced by lowering the freeboard (the distance of the water line to the deck of the ship) of the vessels. Placing the height of the deck just three feet above the waterline, instead of the four or five feet of a general merchant ship, meant that the slaver required still less timber to construct and could load a cargo

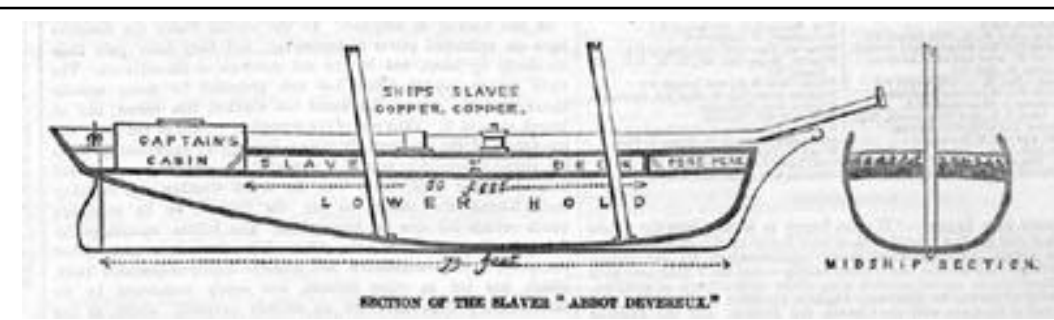

Figure 3.8: The Illustrated London News, Section of the Slaver "Abbot Devereux", 1857, Line Drawing, in The Illustrated London News 31(1857), 284. http://hitchcock.itc.virginia.edu/Slavery/details.php?categorynum=5\&categ oryName $=\&$ theRecord $=40 \&$ recordCount $=78$

even more quickly. The changes in slave ship design and construction practices led to serious problems. Builders reduced weight at the cost of strength by reducing the number and size of timbers in the hull. Although the slightly built hulls could support the lower weight requirements of the slave trade, they may have been insufficient to

\footnotetext{
${ }^{114}$ The Anchorage off the Town of Bonny River sixteen miles from the Entrance. Water Color with Graphite painting, 200mm x 370mm, National Maritime Museum, Greenwich, London. http://collections.rmg.co.uk/collections/objects/106080.html
} 
withstand the forces generated by the ships' large sails.

The weakening of the hull was only the first of several problems with the newer slave ships. The elimination of the lower deck on some vessels made them susceptible to swamping in heavy seas. The chances of this happening were increased by the lower freeboard of the slaver, by the practice of carrying more sail than was customary aboard other merchant ships, and by some owners' preference for larger hatches. $^{115}$

The absence of a lower deck on some slavers also meant that the barrels of provisions could not be wedged in as securely as aboard a ship with a double deck arrangement. Violent storm waves could cause the barrels to shift and overturn the vessel. Additionaly, the lack of a lower deck meant that slaves were forced to lie directly atop water barrels and other provisions. This resulted in the pollution of the water supply by human waste, and sometimes a total loss of the human cargo when disease and disentary spread. A solution to the issue of contaminated water was laying sheets of lead over the water barrels and having slaves lay on top of the lead sheet.

The Abandonment of the lower deck also lead to increased issues surrounding exericiseing slaves and inserections. Firewood was always in great demand aboard ships and was stored in any available corner. In an attempt to provide slaves with a level sleeping surface and store more firewood the gaps between barrels could be filled with firewood. Placing the firewood within reach of the slaves meant that they had a supply of crude, but useful clubs to use as weapons against the crew. ${ }^{116}$ The

\footnotetext{
${ }^{115}$ Junius P. Rodriguez, "Ships," The Historical Encyclopedia of World Slavery Volume 1-7 (Santa Barbara: ABC-CLIO, 1997).

${ }^{116}$ Junius P. Rodriguez, "Shipbuilding," The Historical Encyclopedia of World Slavery Volume 1-7 (Santa Barbara: ABC-CLIO, 1997).
} 
combination of the water barrels, firewood, slaves and other provisions all stowed in a single space, made managing cargo, both human and otherwise a much more difficult task. The ships employed in the slave trade had to undergo dramatic transformations if the commerce were to continue. Known shipwrecks which have already been excavated and analyzed serve as an example for the potential of future sites.

The Enterprise was constructed "specifically for the slave trade". ${ }^{117}$ She was built to replace Thomas Leyland's (a prominent business man who had interests in several slave ships) original ship the Enterprise that he had purchased in $1784 .{ }^{118}$ When this original shipwrecked in Jamaica in 1787, he had another constructed with the same name. ${ }^{119}$ She "was built at Liverpool in the county of Lancaster in 1790." 120

The Guerrero, a square sterned brig, measured just over 323 tons and was just over 110 feet long. She had just one deck and a mounted dragon as a figurehead. Built in 1813 by builder Amasa Miller, a shipwright out of New London Connecticut, the ship's original name was James Monroe. She wrecked on December 19, 1827. Since the vessel has not been found, much of what is known of her construction remains unknown. Based out of Havana, Cuba, the Guerrero was manned by a crew of 90 men and commanded by the pirate Jose Gomez. It ran aground at Carysfort Reff, near Key Largo Fl. Part of an illicit smuggling ring based out of Cuba, she wrecked with 561 African captives on board, after being engaged by HMS Nimble for several hours.

\footnotetext{
${ }^{117}$ Michael Smith, "Locating Slave Shipwrecks, Innovative approaches to digital and archival resources." Presentation Newcastle University, School of History, Classics and Archaeology. . ${ }^{118}$ Matt Smith, The Artefact Biography of a Slave Shipwreck; The Enterprise (Master's Thesis, Barton College, 2010), 24.

${ }^{119}$ St. Jame's Chronicle, August 23, 1787, Issue 4142.

${ }^{120}(\mathrm{C} / \mathrm{EX} / \mathrm{L} / 5 / 2$ 1791.020, C/EXL/5/4: 1801.078)
} 
HMS Nimble was part of the group of ships hunting down slavers after the abolition of the slave trade in 1807. The warship also ran aground damaging her keel and rudder. The Guerrero was a total loss; she sank immediately drowning at least 41 of the Africans on board after the hull breached on the coral and the mast collapsed. ${ }^{121}$

It is thought that the navy may have fired upon or burned the remains of the ship that were still above water; this would eliminate the signs that this was a dangerous place. ${ }^{122}$ If found and excavated, as is the hope, it would be the first ship of its kind to be excvated with the possibility of finding the remians of captive slaves on board, and the only vessel to be excavated that went down as slaver. The vessel is thought to lie somewhere in what is today Biscayne National Park.

The Trouvadore, a brigantine that sank in 1841 was named for the Spanish word wandering minstrel. The vessel was attempting to cross the Atlantic without being detected by the British navy. ${ }^{123}$ She is estimated to be 100 feet long and 25 to 30 feet in the beam. This is based on the account that she departed Africa with around 300 slaves and 20 crew. ${ }^{124}$ Sailing under Spanish papers from Santiago, Cuba she was probably owned by the Canot family. ${ }^{125}$ In the search for the ship, a document known as the "Equipment Clause" was used to help possibly identify the wreck. This clause was established by the British navy to facilitate the capture of slave ships that had no slaves on board. The British navy could do this because the clause outlined the

${ }^{121}$ Gail Swanson, "The Wrecking of the Laden Spanish Slave Ship Guerrero off the Florida Keys, in 1827," African Diaspora Archaeology Newsletter 13:3 (2010): 4.

${ }^{122}$ Ibid., 9 .

${ }^{123}$ Nigel Sadler, "The Trouvadore Project: The Legacy of a Sunken Slave Ship," The African Diaspora Archaeology Network 1:27 (2007):4.

124 "Slave Ship Archaeology, Sorting Through the Clues," Turks and Caicos National Museum. Accessed Dec. 2014, http://slaveshiptrouvadore.org/search-for-trouvadore/slaveship-archaeology/. ${ }^{125}$ Nigel Sadler, "The Trouvadore Project: The Legacy of a Sunken Slave Ship," The African Diaspora Archaeology Network 1:27 (2007):5. 
equipment that was used in the trade. If this was found on board the ship was determined to be a slaver. The identified equipment included excessive water barrels and large cook pots. It also included lattice covers to the ships' holds which allowed air to the captives below deck, and any other items that suggested the ship was fitted for human cargo. ${ }^{126}$

Archival records suggest that salvage took place at the time of wrecking and that "the salvaged items including sails, rigging and chain cables" be turned over to the Spanish consul in the Bahamas. ${ }^{127}$ The British did not turn over the salvaged material but instead sold it for 71.3 pounds sterling. ${ }^{128}$ This amount implies that the recovery and salvage were extensive. It also suggests that the hull may still be intact and that the initial investigations of the team in Turks and Caicos could yield more results related to this wreck. Wood and ballast from the wreck yielded no further identification of the ship, but the ship was identified through the process of elimination. ${ }^{129}$ The artifacts recovered from the site were few and far between, as the wreck has been subjected to over a hundred years for winds, hurricanes and tides. Glass and pottery was recovered but no diagnostic information was gleaned from it when examined in 2006.

The James Matthews was first discovered in July of 1973 by a local dive club. ${ }^{130}$ Classified as a 167-ton AE1 snow brig by Lloyds Shipping Register in 1840,

\footnotetext{
${ }^{126}$ Ibid., 16.

${ }^{127}$ Customs. 34/288, p 340

${ }^{128}$ Co $23 / 101$ p 64

129 "Slave Ship Archaeology, Sorting Through the Clues," Turks and Caicos National Museum. Accessed Dec. 2014, http://slaveshiptrouvadore.org/search-for-trouvadore/slaveship-archaeology/.

${ }^{129}$ Graeme Henderson. "The Wreck of the Ex-Slaver 'James Matthews'." International Journal of Historical Archaeology 12 (2008), 40.

${ }^{130}$ Graeme Henderson, "The Wreck of the Ex-Slaver 'James Matthews,"” International Journal of Historical Archaeology 12 (2008):40.
} 
she was a "one deck, two masts, square stern vessel with a male bust figurehead and no galleries." ${ }^{131}$ James Matthews dimensions were 80x21x11.5 feet. The wreck lay in 10 feet of water just under the sand about 330 feet from the shore, at Woodman Point, in Western Australia. ${ }^{132}$ A British registered ship, she met her fate while bring settlers and equipment to the Australian colony at Swan River in $1841 .^{133}$

Before her career as a passenger vessel, the James Matthews worked as a slaver. ${ }^{134}$ She was French built and listed as 108 tons, when captured by the HM Brig Griffon in 1837 with 439 slaves on board. Previously named the Voltiguer by the French, then the Don Francisco when she went under a Portuguese flag. The latter was an attempt to avoid being captured. It was not until after the vessel was sold in condemnation in 1837 that she was renamed James Matthews. ${ }^{135}$

Like her companion vessel, the American barque Gentil, the James Matthews was built for the slave trade, despite the fact that it was illegal in most of the world. ${ }^{136}$ She was owned by a man named Da Souza, and plied the trade with other ships. Da Souza had his ships built in the United States. When in 1825 , his newly built schooner Principe de Guine was captured, finished recently in Philadelphia, a Royal Navy Captain commented that it was "the best built of all known American ships." 137 Excavated expertly by the archeologist and volunteers of the Western Australia Museum, data related to James Matthews' time as a slave ship was extrapolated.

\footnotetext{
${ }^{131}$ Ibid., 41.

${ }^{132}$ Ibid., 39.

${ }^{133}$ Ibid., 41.

134“"James Matthews,” Western Australian Museum, accessed Jan. 2014, http://museum.wa.gov.au/research/research-areas/maritime-archaeology/treasures-from-the-deep/jamesmatthews

${ }^{135}$ Graeme Henderson, "The Wreck of the Ex-Slaver 'James Matthews,"” International Journal of Historical Archaeology 12 (2008):41.

${ }^{136}$ Ibid., 50.

${ }^{137}$ Ibid., 44.
} 
Despite the fact that she did not sink as a slaver, the lines taken from the wreck provide a good representation of when she was Don Francisco and carrying slaves. ${ }^{138}$ Rectangular iron gratings recovered from the site suggest the ship had extra fortifications. It was standard practice for these gratings to be wood on most ships, the strong material suggests that these grates are from the ship's time as a slaver.

Additionally, the number of grates is greater than would be expected and smaller than they would be on other standard merchant ships. ${ }^{139}$ Remarkably, much of the ship's rigging is intact, largely due to the way in which she sank and the measures taken by the crew during the wrecking process. The masts were cut away to lessen the force of the wind after the vessel hit the bank. The mast and some rigging were rather unusual. Preserved by the mass of the ship on top of it, these features may offer a unique look into the rigging of vessels looking to cross the ocean speedily. ${ }^{140}$

Many potential future slave ships and associated sites await discovery. A survey of historic newspapers and insurance claims done in 2010 by students at Newcastel Unviersity in the United Kingdom indicate that there 261 wrecks of slavers; 85 British wrecks, 33 Irish wrecks, 97 West African wrecks, 72 Caribbean wrecks, 17 North American wrecks, 6 South American wrecks, and some 31 mid-Atlantic wrecks. ${ }^{141}$ If even a small portion of these where discovered and researched by archaeologists what is known about the structure and construction of slavers would grow exponentially.

\footnotetext{
${ }^{138}$ Ibid., 46.

${ }^{139}$ Ibid., 46.

${ }^{140}$ Ibid., 47.

${ }^{141}$ Michael Smith, "Locating Slave Shipwrecks, Innovative approaches to digital and archival resources," (Presentation Newcastle University, School of History, Classics and Archaeology). Voyages Database. Voyages: The Trans-Atlantic Slave trade Database. Accessed Jan 2014, http://www.slavevoyages.org
} 


\section{CHAPTER 4}

\section{MATERIAL CULTURE}

The hull structure of a shipwreck does not always survive in a submarine environment, but often the material culture on board does. This material can tell researchers much about the slave trade. While material culture can not indicate if a ship was built specifically for the slave trade or not, it does support the hypothesis that the slave trade was a unique undertaking. Archaeological typologies can also help deliniate temporal and regional differences in the slave trade.

Goods produced in Europe were brought to West African factories (fort-like structures that served as trading posts in Africa that were both secure and accessible) en masse first by the Portuguese in the late $15^{\text {th }}$ century and later by the other colonial powers. ${ }^{142}$ Trade items that were desirable on the coast were highly specific and regional. Specific items traded in particular ports required merchants, even in the early years of the trade, to plan ahead. Planning what items would be traded in what port allowed for some insurance so that, even when trade items flooded the market in Africa inflation was hardly noticed. Trade beginning on the African coast would soon penetrate the African continent, meaning that inflation only caused a slight devaluing of trade items. Distribution of trade items towards the interior of Africa and accumulated goods allowed for some individuals to become very wealthy and 
accumulate power. ${ }^{143}$

At specific points along the Western Coast of the Africa cargo of slaves could be acquired. The center of export and trade shifted over time. With the exception of the period from 1676 to 1725 , the stretch of coast from Cape Lopez in modern day Gabon to Benguela in modern day Angola, supplied more slaves than anywhere else. ${ }^{144}$ By 1600 , this area was established as the trade's center. However, slave exports underwent an extreme expansion in every region during the Eighteenth century. This expansion climaxed in roughly 1775 . Brazilian slavers went as far as rounding the Cape of Good Hope to fill their vessels hold. West Central Africa sent more slaves than all of the other regions combined. ${ }^{145}$

"Money", as it is known today, is a European concept brought to Africa by colonization. The idea of coin and cash as currency, however, is one which did not truly take hold in many places in until the end of the Second World War. ${ }^{146}$ For much of the early modern period, the various regions of Africa used different commodities as currency when trading and conducting transactions. Commodity can be defined simply as a socially desirable thing with a use-value and an exchange value. ${ }^{147}$ The Portuguese's and later other Europeans powers, quickly realized that the use of precious metals and coin could be forgone. Instead, trade goods already being produced in Eurpoe and imported to africa were sufficient for trade.

\footnotetext{
${ }^{143}$ Paul Einzig, Primitive Money; in its Ethnological, Historical and Economic Aspects (Oxford: Pergamon Press. 1966), 137.

${ }^{144}$ David Eltis, "Early Slaving Voyages," A Brief Overview of the Trans-Atlantic Slave Trade (Emory University, 2007). http://www.slavevoyages.org/tast/assessment/essays-intro-02.faces

${ }^{145}$ David Etlis, "The African Side of the Trade," A Brief Overview of the Trans-Atlantic Slave trade (Emory University, 2007) http://www.slavevoyages.org/tast/assessment/essays-intro-06.faces

${ }^{146}$ Paul Einzig, Primitive Money: In its Ethnological, Historical and Economic Aspects (Oxford: Pergamon Press, 1966), 136.

${ }^{147}$ Greg Cook, "The Maritime Archaeology of West Africa in the Atlantic World: Investigations at Elmina, Ghana,” (Dissertation, December 2012), 52.
} 
Many potential trade items were already being produced in Africa, but the "prestige, fancy, changing taste and desire for variety" created a market for the products imported to the continent. ${ }^{148}$ Western perspective has perpetuated the idea that the most common trade goods were firearms, cheap liquor, trinkets, and

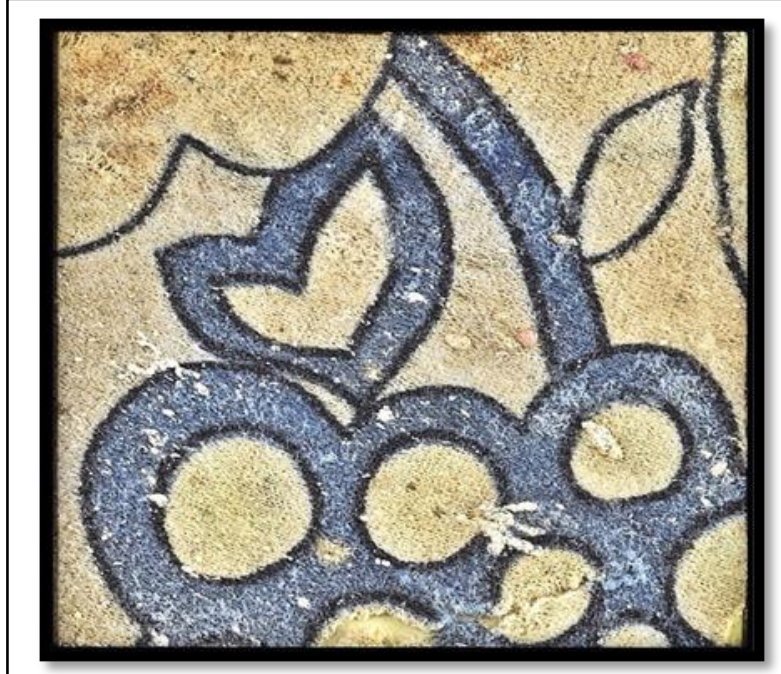

Figure 4.1: National Museum of Bermuda, Instagram post, September 8, 2014,

http://instagram.com/p/sr2Qfshxbb/?modal=true

useless luxuries items shuffled around the globe in a triangle. In fact, the

European/African trade was dominated from start to finish by practical cloth and metal goods. "The range of commodities was so broad that inbound European ships eventually came to resemble what one specialist has called "floating supermarkets." ${ }^{149}$ In 1645, the Dutch inventoried 92 different trade goods on the Gold Coast and trade only expanded from there. ${ }^{150}$

Goods produced anywhere within the European influence were brought to Africa for trading. The items, however, were highly regionalized and changed as often as fashion does today. Traders attempted to anticipate West Africans tastes in fabric's, bead, ceramics, and other commodities, often going to great lengths to ensure

\footnotetext{
${ }^{148} \mathrm{John}$ Thornton, Africa and Africans in the Making of the Atlantic World, 1400-1680. (Cambridge, 1992), 44-45.

${ }^{149}$ A.G. Hopkins, An Economic History of West Africa (London, 1973), 111.

${ }^{150}$ Stanely B Alpern, "What Africans Got for Their Slaves: A Master Lift of European Trade Goods," History in Africa 22 (1995): 6.
} 
that a voyage would be profitable. ${ }^{151}$ An item manufactured and brought to western Africa may no longer be desirable, when the ship finally arrived. Change in destination after a ship had been loaded and fitted for a specific place with specific goods for that port, could spell ruin, something slave ship captains understood but ship owners often did not. ${ }^{152}$

Arriving at a port with no desirable trade items was clearly worse than several ships arriving at the same port with similar items to trade. Nevertheless, when several ships arrived in Africa at the same time, the value of the items could be deflated.

Because of this trend, items that survive in the archeological record have the potential to be highly diagnostic and could be identifiers to where a ship was headed, where it was coming from, and when it was traveling when a wreck is discovered.

Cloth and fabric was the most commonly traded items. Cloth and shawls were among the first goods marketed by the Portuguese, and ones which they had the most success trading for slaves. During the eighteenth century, nearly two-thirds of goods sent to Africa in each decade consisted of textiles. ${ }^{153}$ Between 1714 and 1715 , half of the 2000 enslaved Africans purchased by the Dutch West India Company were purchased with textiles. ${ }^{154}$ The name of the textile indicated its origin, many of which came from Morocco and Tunisia, and later from European countries. ${ }^{155}$ The spellings fluctuate over time and Africans preferred to purchase unfinished cloth that they could

\footnotetext{
${ }^{151}$ Greg Cook, "The Maritime Archaeology of West Africa in the Atlantic World: Investigations at Elmina, Ghana," (Dissertation, December 2012), 52.

${ }^{152}$ Leo Balai, Slave Ship Leusden: A story of Mutiny, Shipwreck, and Murder (Norwich: UTS publishing, 2013) Kindle Edition, location 686.

${ }^{153}$ Greg Cook, "The Maritime Archaeology of West Africa in the Atlantic World: Investigations at Elmina, Ghana," (Dissertation, December 2012), 81.

${ }^{154}$ Ibid., 75.

${ }^{155}$ Ibid., 76.
} 
then dye to their specifications. ${ }^{156}$

Cloth and textiles were imported in great diversity, were highly regional, and can serve as diagnostic tools if they survive in the archaeological record. The number of different cloths and their description would require an independent study, but some of the more common types are known and are often still in use today. Anabas, a strong fabric, is used for bedding and lining. ${ }^{157}$ Also known as fustian in Haarlem and Leiden and produced for nearly seven centuries, this wool cloth fabric was exported through Amsterdam. There are roughly 180 different types of Anabas which were manufactured mainly through the home industry which reached its zenith in 1641 before declining in the mid-1850s. ${ }^{158}$ This cloth was shipped mainly to Dutch colonies.

Other common fabrics include Atlas, a stripped fabric made of silk and Baftas, a black and white cotton cloth usually very course in nature and made in India. Broulisses is dyed linen from Gujarat, India. Caffa is a painted silk or cotton sometimes with a flower motif made in India starting in the $16^{\text {th }}$ century. Originating in Bengal, Cassa is a loosely woven smooth soft fabric, similar to muslin. Chintz is a colored cotton calico from India. ${ }^{159}$ Cora cloth, a fine, woven silk, was often used for loincloths. Guineas, also knowns as brawles, capperees, chelloes, hussaness, and pautkas is a plain white, loom-patterned, or piece-dyed cotton textile. Woven in India

\footnotetext{
${ }^{156}$ Ibid., 78.

${ }^{157}$ Leo Balai. Slave Ship Leusden: A story of Mutiny, Shipwreck, and Murder. (Norwich, UK:UTS publishing, 2013) Kindle Edition, location 633.

158 “Seven Centuries of Leiden Cloth," Leiden Museum De LAKENHAL, Accessed Feb. 2015, http://lakenhal.nl/en/story/leiden-cloth

${ }^{159}$ Kax Wilson, A History of Textiles (Boulder: Westview Press, 1979), 97.
} 
and sent to Europe, it was then re-exported to the Guinea Coast. ${ }^{160}$ Lemeniasses, is a European woven cloths with blue with little white stars. Perpetuan, a very strong, serge-like fabric, is originally from Portugal, later manufactured in England and France. Originally, perpetuan was a woolen or cotton fabric, often used for lining. Plattilles, is a fine muslin veil-like cloth, is mostly self-colored black, green, purple or indigo, but can also be checkered. Raw Guineas, is an unbleached cotton fabric preferred for its ability to be customized. Saai, a simple and affordable kind of sheet made from woolen fabric produced primarily in Leiden. Finally Salempouris, a textile named after Salempors or Semampore in Coromandel, was manufactured in India but its uses in Africa are unknown. ${ }^{161}$

Fabric has been found on the Manilla wreck, a scrap of French-made 'Indienne' fabric, of a type made in the slave-trading port of Nantes, together with thousands of glass beads and manillas (bronze bracelets) used in the slave trade. This was a surprising discovery as the waters in Bermuda are tropical and do not lend to the anaerobic environment that encourages the preservation of organics. This fabric was discovered after the site had been picked over by treasure hunters. ${ }^{162}$ The case of the manilla wreck shows that with careful excavation fabric can be recovered and identified.

\footnotetext{
${ }^{160}$ J.S. Hogendorn and H.A. Gemery, "The 'Hidden Half' of the Anglo-African Trade in the Eighteenth Century: The Significance of Marion Johnson's Statistical Research" in West African Economic and Social History: Studies in Memory of Marion Johnson, David Henige and T. C. McCaskie, eds. (Madison: University of Wisconsin African Studies Program, 1990). The 'hidden half' refers to the commodities Europeans exchanged for slaves, ivory, pepper, and other African trade goods.

${ }^{161}$ Leo Balai, Slave Ship Leusden: A story of Mutiny, Shipwreck, and Murder (Norwich, UK:UTS publishing, 2013) Kindle Edition, location 649.

${ }^{162}$ National Museum of Bermuda, Instagram post, September 8, 2014, http://instagram.com/p/sr2Qfshxbb/?modal=true
} 
While fabric and cloth do not

often survive in the archeological

record, bale seals do. Bale Seals are

lead seals used by inspectors of ships

from 1300 to 1800 , when inspecting

items shipped in bales. They allowed

for counting and measurements when

assessing taxes and port fees. Bale

seals encountered on archeological

sites consist of "two connected disks

of lead that were bent over the corner

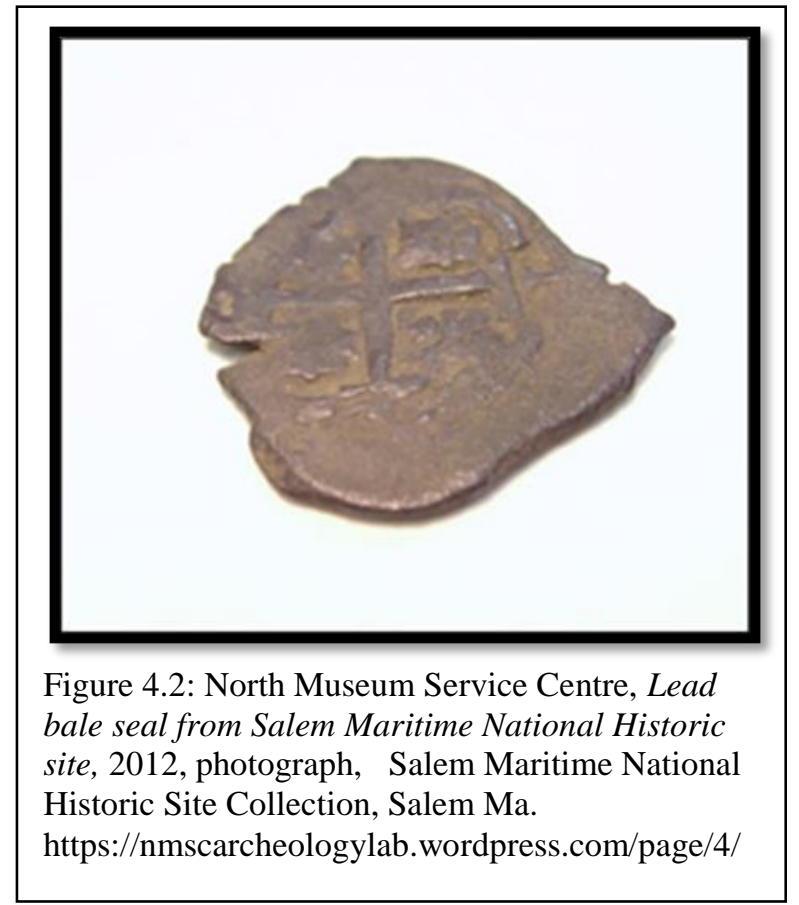

of a bolt of cloth... and clamped tight with a device that impressed the lead with various symbols, numerals, and letters."163 Bale seals were often marked with cities, dates, company names and accounting numbers which have the potential to be highly diagnostic. ${ }^{164}$

In addition to bale seals, dyes and other items that would help someone individualize fabric have been discovered on board sunken vessels. Logs of 'purpleheart' dyewood where discovered on the Henritta Marie. ${ }^{165}$ Indigo was by far the most popular dye in West Africa as it was produced there. It got a good price both on the African coast, in Eurpoe and North America. ${ }^{166}$

\footnotetext{
${ }^{163} \mathrm{Al}$ Luckenbach and C. Jane Cox, "17th Century Lead Cloth Seals from Anne Arundel County, Maryland," Maryland Archeology 39 (2000): 17.

${ }^{164}$ Ibid., 17-26.

${ }^{165}$ Corey Malcom, "The Re-examination of the Hull of the Henrietta Marie," Mel Fisher Maritime Heritage Society, Key West, 2001.

${ }^{166} J$ ohn Gillow, African textiles: Color and Creativity across a Continent (Thames \& Hudson, 2009), 62.
} 
Different metals imported to the

African coast penetrated the continent.

Metal objects were the second most

popular item to be brought to the coast.

Metal available in Africa was not as

pure as that available elsewhere not

because those in Africa did not have the

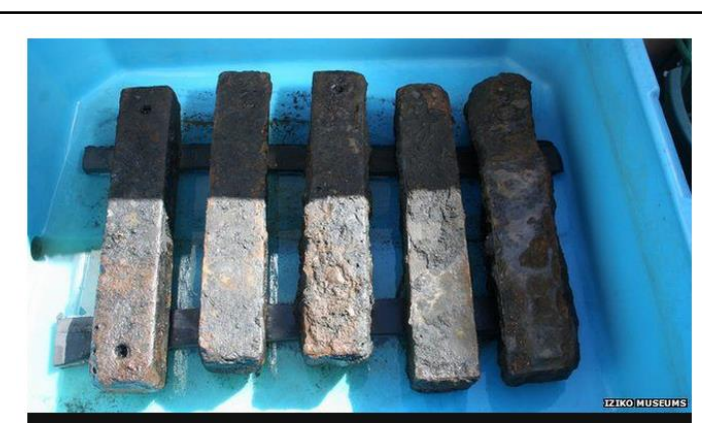

Figure 4.3: Iziko Museums, Iron bars. Picture, 2015, accessed June 15, 2015

http://www.smithsonianmag.com/smithsonianinstitution/sunken-18th-century-slave-ship-

found-south-africa-180955458/?no-ist

resources but because refining techniques were superior in Europe. The many skilled smiths in Africa had a preference for producing the raw material on their own. Copper and brass became a favorite due to their long lasting nature when used in utilitarian ways. $^{167}$

Iron bars were used as an accounting unit along the Niger Delta; ships carrying iron bars of varying lengths and weights came to Africa in the thousands. ${ }^{168}$ African smiths then reworked the metal into tools and other goods. The size and weight varied, but all were shipped flat. ${ }^{169}$

Unlike their iron counterparts, copper rods, were round in cross-section. Used mainly in Old Calabar (the southern part of Niger), they ranged from 34 inches to 40 inches and weight's varied. Smiths in Calabar drew the copper out like wires and braided them into necklaces and bracelets. ${ }^{170}$ Manillas were brass or copper open-

\footnotetext{
${ }^{167}$ Stanley B. Alpern "What Africans Got for Their Slaves: A Master Lift of European Trade Goods." History in Africa 22 (1995): 13.

${ }^{168}$ Elizabeth Donnan, Documents Illustrative of the History of the Slave Trade to America (Washington, 1931-35), 262.

${ }^{169}$ Stanley Alpern, "What Africans Got for Their Slaves: a Master List of European Trade Goods" History in Africa, 22(1995):12.

${ }^{170}$ Leo Balai, Slave Ship Leusden: A story of Mutiny, Shipwreck, and Murder (Norwich, UK:UTS publishing, 2013) Kindle Edition, location 655.
} 
ended bracelets or rings that were flared slightly at each end in a bell shape. ${ }^{171}$ These bracelets, were traded from the earliest European participation in the slave trade up through the nineteenth century. ${ }^{172}$ While the word "manilla" simply means "ring of metal" it is typically horseshoe shaped and measures on average two and a quarter inches across and weighs around $3 \mathrm{oz} .{ }^{173}$ Traded mostly in the Niger Delta region, manillas were one of the primary trade commodities used in exchange for the 3.5 million slaves shipped from Nigeria to the Americas during the Seventeenth, Eighteenth and Nineteenth centuries. ${ }^{174}$ Towards the end of this period, manillas made of lead, pewter, iron and tin were traded along with the brass and copper. As the trade continued, the quality of metal used in manillas decreased as did their weight. ${ }^{175}$

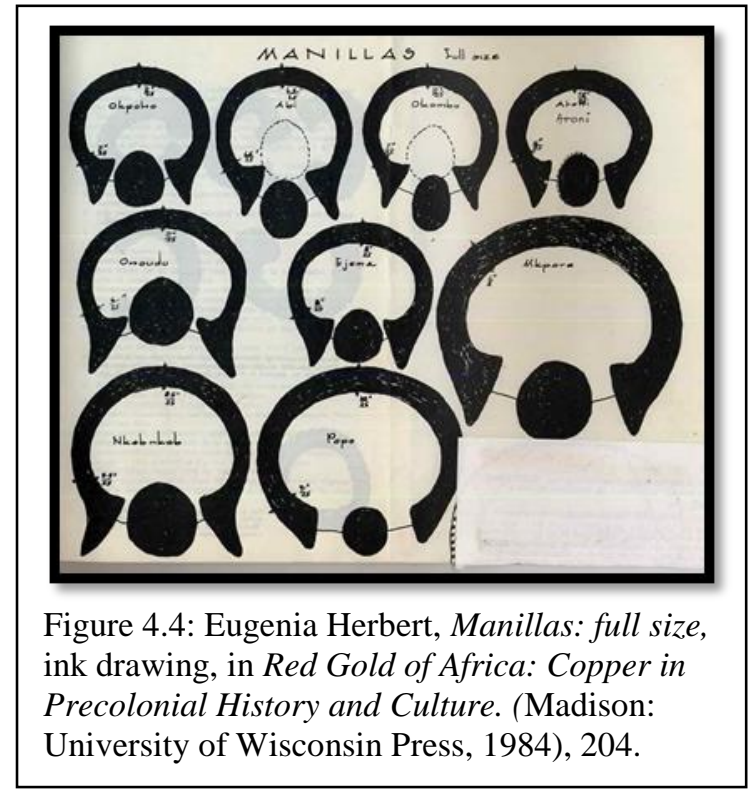

On rare occasions, Manillas have been found on archaeological sites.

Discovered on the Manila Wreck, the Elmina Wreck, and sporadically on other wrecks, manillas are synonymous with the slave trade. Surprisingly little evidence of manillas in terrestrial excavations in West Africa exists. Little definite information

\footnotetext{
${ }^{171}$ Stanley B. Alpern, "What Africans got for their Slaves: A Master List of European Trade gods," History in Africa 22 (1995), 13.

${ }^{172}$ Eugenia W. Herbert, Red Gold of Africa; Copper in Precolonial History and Culture (Madison, University of Wisconsin Press, 1984), 125-132.

${ }^{173}$ Ibid., 201.

${ }^{174}$ U.S. Library of Congress, Helen Chapin Metz, ed. "Slave Trade," in Nigeria: A Country Study (Washington: GPO for the Library of Congress, 1991), accessed March 2013, http://countrystudies.us/nigeria/7.htm.

${ }^{175}$ Leo Balai, Slave Ship Leusden: A story of Mutiny, Shipwreck, and Murder (Norwich: UTS publishing, 2013) Kindle Edition, Location 13.
} 
exists regarding their varieties or characteristics though there is a rough typology as seen in Figure 4.4. ${ }^{176}$

The commercial salvage company Arqueonautas recovered 238 manillas off a sixteenth century wreck in Getaria Bay, northern Spain, and has published a brief report. ${ }^{177}$ The wreck is significant in that it was likely a Flemish vessel chartered by Portugal to ship its cargo to São Jorge da Mina and the manillas appear to be similar in form to those from the Elmina Wreck, despite their earlier date. Manillas were also found on the 1629 wreck of the Dutch East Indiaman Batavia, but these are strikingly different from manillas recovered from the sites mentioned above, Moreover, they exhibit a more circular diameter and claw-foot ends ${ }^{178}$ A single manilla recovered from an early eighteenth-century wreck off Saint-Quay Islands in Brittany is similar in form to the manillas from the Elmina Wreck. ${ }^{179}$ Finally, a "large number" of manillas and trade beads were discovered in association with 24 cannons by sports divers 6 miles (9.6 kilometers) northeast of Bermuda. Dubbed the "Manilla Wreck," the site was investigated archeologically in 1998-1999 and the artifacts determined to have been to cast overboard likely during a grounding incident in the mid-eighteenth century. ${ }^{180}$ In an article on the analysis of the beads found at the site, Karklins includes an image showing a variety of the recovered finds, including a stack of manillas that

\footnotetext{
${ }^{176}$ Christopher R. Decorse, An Archaeology of Elmina: Africans and Europeans on the Gold Coast, 1400-1900 (Washington: Smithsonian Institute Press, 2001), 147.

${ }^{177}$ A. Benito and M. Ibanez, "Gaceta Numismatica" (2005): 63-81.

178 Jeremy N. Green, The Loss of the Verenigde Oo'stindische Compagnie retourschip Batavia, Western Australia 1629 an Excavation Report and Catalogue of Artifacts. BAR International Series 489. (British Archaeological Reports, Oxford:1989), 191.

${ }^{179}$ Herry Nolwenn, "Report on the Finds from the Saint-Quau-Portrieux Wreck, France," The International Journal of Nautical Archaeology 33 (2004):97.

${ }^{180}$ Clifford Earle Smith, "The Manilla Wreck: Bermuda's role in the Atlantic slave-Smuggling Trade," (PhD diss., University of Kentucky, 2003), 15.
} 
are comparable in form to the type found on the Elmina Wreck. ${ }^{181}$

Other metals include lead, gold, silver, and ivory. Lead brought into Namakwaland (South Africa) in bar form would be converted into musket balls, slugs, and fishing sinkers once it arrived in Africa. ${ }^{182}$ Gold was mainly brought in by

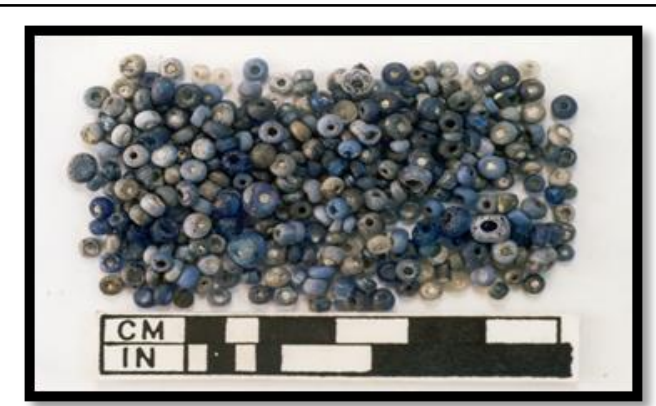

Figure 4.5: Corey Malcom, Glass 'seed' beads, 2001, photograph, in Corey Malcom "A Collection of Artifacts Recovered from the Shipwreck Henrietta Marie, 2002." Mel Fisher Maritime Heritage Society, Key West, 2002.

the Portuguese from Brazil, who were using a large portion of the slaves they transported to operate the mine there. English and Rhode Islander merchants brought gold to the Gold Coast from 1767 until 1796, but soon realized that effective trade could take place with trade goods rather than precious metals. ${ }^{183}$ Ivory, though not metal, could be used in Elmina to exchange for slaves. Ivory includes both elephant tusks and teeth. In 1724, 121 captives were traded for 280 pounds of ivory. ${ }^{184}$ Ivory was also discovered aboard the wreck of the Fredensborg, suggesting that ivory went the way of other precious metals over time and trade goods took its place. Silver brought over mostly as coins, was melted down and turned into jewelry and other ornaments, as coin money was not used in Africa widely until after the Second World War.

As precious metals became less common and trade goods grew in popularity

\footnotetext{
${ }^{181} \mathrm{~K}$. Karklins, "Beads from the Mid-18th-century Manilla Wreck, Bermuda," The International Journal of Nautical Archaeology 20:1 (1991):39.

${ }^{182}$ Stanely B. Alpern, "What Africans Got for Their Slaves: A Master Lift of European Trade Goods," History in Africa 22 (1995), 14.

${ }^{183}$ Ibid., 14.

${ }^{184}$ Leo Balai, Slave Ship Leusden: A story of Mutiny, Shipwreck, and Murder, (Norwich: UTS publishing, 2013) Kindle Edition, Location 889.
} 
the use of items such as basins, pans, pots, kettles, dishes, tankards, buckets, and nepts were even more common. Nepts, type of bowl, were made of copper or tin, and were used for a wide variety of purposes, including mining, bathing, shaving and even blood gathering rituals. ${ }^{185}$ Spanish Bowls were made and imported for the extraction of salt and for boiling sea water. These small metal bowls were also used for the slaughter and plucking of poultry. ${ }^{186}$ When discovered in the context of an archaeological wreck they are often still neatly stacked and sorted.

One of the most common trade goods discovered on ships that were formally slavers or ships that sank on a leg of the journey other than on the way to Africa are glass beads. ${ }^{187}$ Manufactured all over Europe, but primarily in Italy and Spain, glass beads often found their way down into the ballast of a ship and thus remain in the archeological record. Glass beads also end up in concretions and in every nook and crack of shipwrecks. Beads were often transported in bundles strung together, but when a single stand broke the beads could easily make their way through the boards of a ship to be logged in a location too difficult to be recovered.

There were thousands of varieties of glass beads. Particular beads were popular along particular parts of the African coast and went in and out of fashion. Again a complete study of trade beads is beyond the scope of this study and could be undertaken as its own study. The trade in Venetian beads was general all along the coast from Senegal to the Bight of Benin. From the Bight to the Gold Coast, blue

\footnotetext{
185 Ibid., Location 655.

186 Ibid.

${ }^{187}$ Stanely B. Alpern, "What Africans Got for Their Slaves: A Master Lift of European Trade Goods," History in Africa 22 (1995):22.
} 
stone and coral was purely a local trade. ${ }^{188}$

Between 1714-1715, 800 of the enslaved Africans acquired by the Dutch

West India Company were purchased with Cowries, nearly half, whereas only 200 were purchased with guns and powder. ${ }^{189}$ Cowries are shells that are traded as beads; they are not native to Africa but have been washing ashore for years. All examples recovered from the

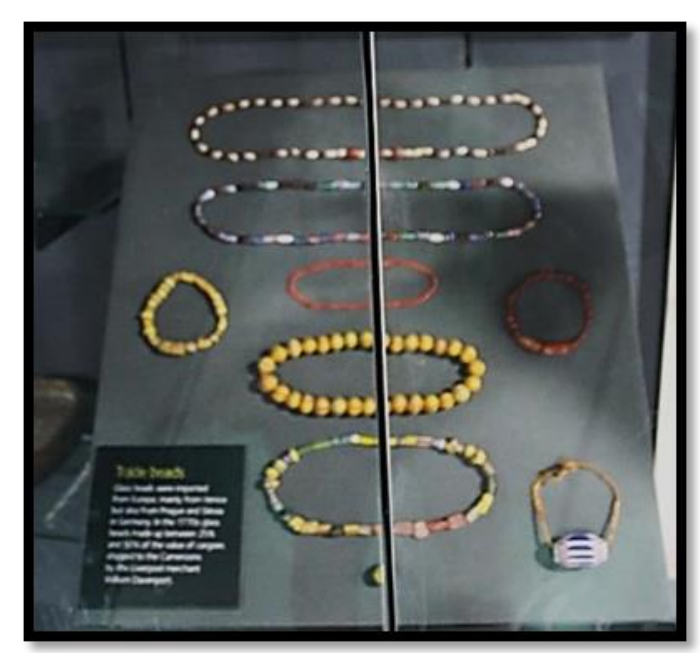

Figure 4.6: Jessica Glickman, Beads at the Liverpool Museum, Photograph, 2013, personal collection of photographs.

Elmina Wreck in 2005 are identified as Cypraeamonetaor the traditional "money cowrie" indigenous to the Indian Ocean and Pacific. ${ }^{190}$

These cowrie shells were imported by the billions intoWest African markets for use as currency, one advantage being that they could not be counterfeited since no similar shells exist in West Africa. ${ }^{191}$ While small items such as cowries could easily be transported by currents and surge, their numbers and context in certain locations suggest that a ship wreck in nearby. ${ }^{192}$ In the case of cowries, shipwrecks have caused confusion. Cowries are not native to Africa. Since money cowries are still washing up

\footnotetext{
${ }^{188}$ A.W. Cardinal, “Aggrey Beads of the Gold Coast," Journal of the Royal African Society 24 (1925):289.

${ }^{189}$ Johannes Postma, The Dutch in the Atlantic Slave Trade, 1600-1815 (Cambridge: Cambridge University Press 1990), 103.

${ }^{190}$ Felix Lorenz and Alex Hubert, A Guide to World Cowries (Wiesbaden: Verlag Christa Hemmen, 1993), 205.

${ }^{191}$ Sven-Olof Johansson, Nigerian Currencies: Manillas, Cowries and Others (Skolgatan, Norrkoping: Alfa-Tryck, 1967), 34

${ }^{192}$ Greg Cook, "The Maritime Archaeology of West Africa in the Atlantic World: Investigations at Elmina, Ghana," (Dissertation, Syracuse University, 2012), 204.
} 
on shore from wrecks along the coast this has caused confusion. ${ }^{193}$ West African cowries were supplied primarily from the Maldives. ${ }^{194}$

\begin{tabular}{l|l|} 
cowries but \\
lacking the \\
characteristic lip \\
are olive shells, \\
which have been \\
found on West \\
African beaches.
\end{tabular}

Also known as "zimbos" these shells are from the Atlantic and dominated the kingdom of Kongo. ${ }^{195}$ In Ardra, merchants needed to be paid in cowries, the Leusden brought 95 barrels of the shells weighing 27,268 Amsterdam pounds (1 pound is equal to 494 grams). In a report from 1731, an enslaved man was worth 230 pounds of cowrie shells and 48 items of textile. ${ }^{196}$

Aggrey Beads are found along the Gold Coast. There are three varieties of beads which use this name. The first is single colored, the second is a mosaic and the third is striped. ${ }^{197}$ Different colors and designs where preferred by different groups.

\footnotetext{
${ }^{193}$ Jan Hogendorn and Maron Johnson, The Shell Money of the Slave Trade (Cambridge University Press, 2003), 12.

${ }^{194}$ Ibid., 14.

${ }^{195}$ Ibid., 19.

Kongo was a kingdom in west central Africa that at its height reach from the Atlantic ocean to the Kwango river. Today this area is occupied by several countries including Angola, Cabibinda, and the Republic of the Congo.

${ }^{196}$ Leo Balai, Slave Ship Leusden: A story of Mutiny, Shipwreck, and Murder (Norwich: UTS publishing, 2013) Kindle Edition, location 884.

${ }^{197}$ A.W. Cardinal, "Aggrey Beads of the Gold Coast," Journal of the Royal African Society 24 (1925): 288.
} 
"The Fantees prefer the plain yellow bead, the Amanaheans the blue and yellow. For which they will give double the weight in gold." 198 What made these beads desirable was there imperfections and age, the older the more desirable. This could make them unreliable as the sole determiner for the date of a site but would help with identifying the region of trade. ${ }^{199}$

Articles of restraint are another item that is commonly found on shipwrecks often encased in concretions. Handcuffs, ankle cuffs, chains and other articles of restraint where always in high demand on the coast because they were always needed. Handcuffs and ankle cuffs have often been the reason that treasure hunters have paused and taken a further look at the wreck they are pilfering. The demand was high for these items because they were always needed, both on ships and on the coast in holding centers. However, in both of these locations the rate of deterioration on these mostly irons items are quite high. Shackles are on the manifest of many a slave ship and they found on many shipwrecks. Shackles are also requested frequently in letters and correspondence both from slave ship captains and agents working on the African coast. When examining the archaeological reports of many of the ships that have been discussed here, these times of restraint are the first indicators that point to the wreck being a slaver. While shackles and chains are a strong sign that a vessel held captives, they are not the only indicators. Items of restraint are the most emotionally and visually compelling item when discussing the human element of the slave trade, but they were moved from place to place, ship to ship, and were created when and where they where needed. As such, they are nearly impossible to use as a typology or dating

\footnotetext{
${ }^{198}$ Ibid., 288

${ }^{199}$ Ibid., 293.
} 
tool. The variety of styles of shackles on the Henrietta Marie illustrates the range of items.

Firearms including

muskets, pistols, cannon, gunpowder, lead ball and shot, gun flints were also popular trade items. Various Eurpoean traders' provided rifles to African buyers both at times of war and times of peace. An estimates of 180,000

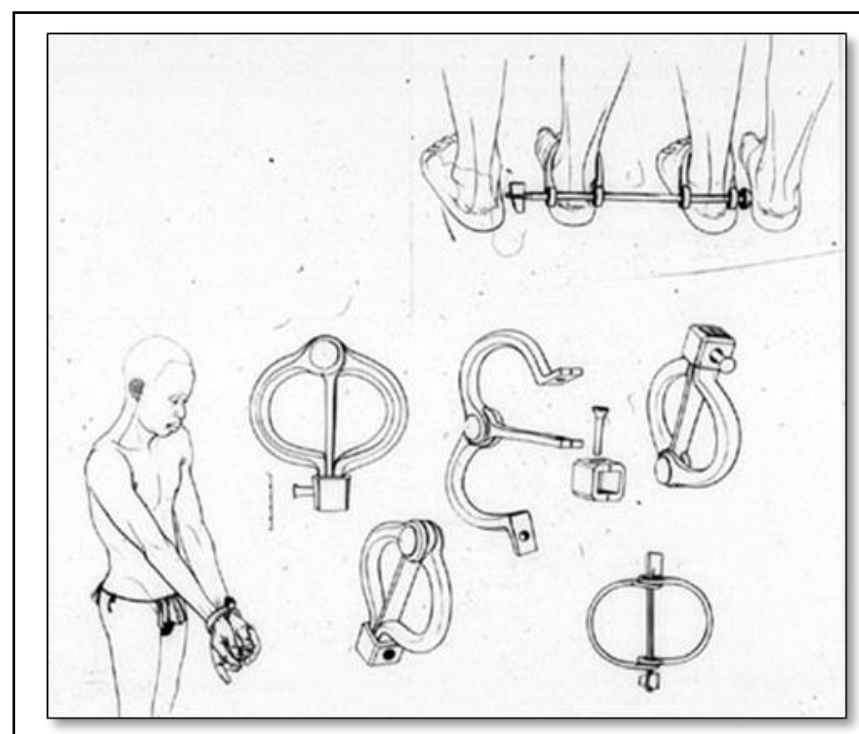

Figure 4.7: Jean Bourdriot, Leg and Wrist Shackles used on Slave Ship, 1784, Line Drawing, in Jean Boudriot, Traite et Navire Negrier l'Aurore, 1784, (Paris, Published by author 1984), 84 . http://hitchcock.itc.virginia.edu/Slavery/details.php?cate gorynum $=5 \&$ categoryName $=\&$ the Record $=34 \&$ recordCo unt $=71$

to 394,000 rifles where imported each year. ${ }^{200}$ Firearms are not particularly diagnostic, with the possible exception of cannons, as they are found on every merchant vessel. It is the number of firearms and the frequency with which they are traded, much like chains and shackles, that makes firearms possibly unique material items. Unfortunately, all firearms, including canons, moved from hand to hand and ship to ship making it nearly impossible to track them to any single location or trade Voyages aboard a slaver, like other merchant vessels, lasted anywhere from a few months to years. While the ships would make port several times items need to have a successful journey where not available at each port. Sailors are also known to collect items from the ports that they visited. Other items that are found and related to life aboard a vessel include cutlasses, swords, razors, scissors, pins, needles, thimbles,

${ }^{200}$ Leo Balai. Slave Ship Leusden: A story of Mutiny, Shipwreck, and Murder (Norwich, UK:UTS publishing, 2013) Kindle Edition, location 649. 
fishhooks, locks and keys, tools and pipes. Of these items, pipes and pipe stems are the most datable; they have been studied extensively and are used across historical archaeological studies. ${ }^{201}$ The presence of specific tools can indicate whether or not a carpenter or doctor was on board.

The number of items that could be on a slave ship is just as abundant as any other vessel. Items such as ceramics, bottles, bone fragments, shoes, and clothing can tell much about life on board a ship or identify the specific ship discovered. These items don't, however, point to a ship being a slaver before the ship is identified by name. A goal of the archaeologist should be to identify a ship as a slaver by the material recovered without simply reverting to the presences of shackles and chains. A further understanding of the trade goods traveling across the Atlantic, beyond rum and people, could help to discover more of these sites and correctly identify them for what they are.

${ }^{201}$ Lauren McMillan, "Put This in Your Pipe and Smoke it: An evaluation of Tobacco Pipe Stem Dating Methods,” (Master's thesis, East Carolina University, 2010). 


\section{CHAPTER 5}

\section{HISTORICAL DOCUMENTS}

There are massive numbers of historic documents related to the slave trade. The slave trade was a profitable business with a complex system of markets and trade routes. The high-risk, high-reward nature of the trade invited a wide range of merchants and entrepreneurs to enter, generating documents related to every aspect of the business. The sheer number of people

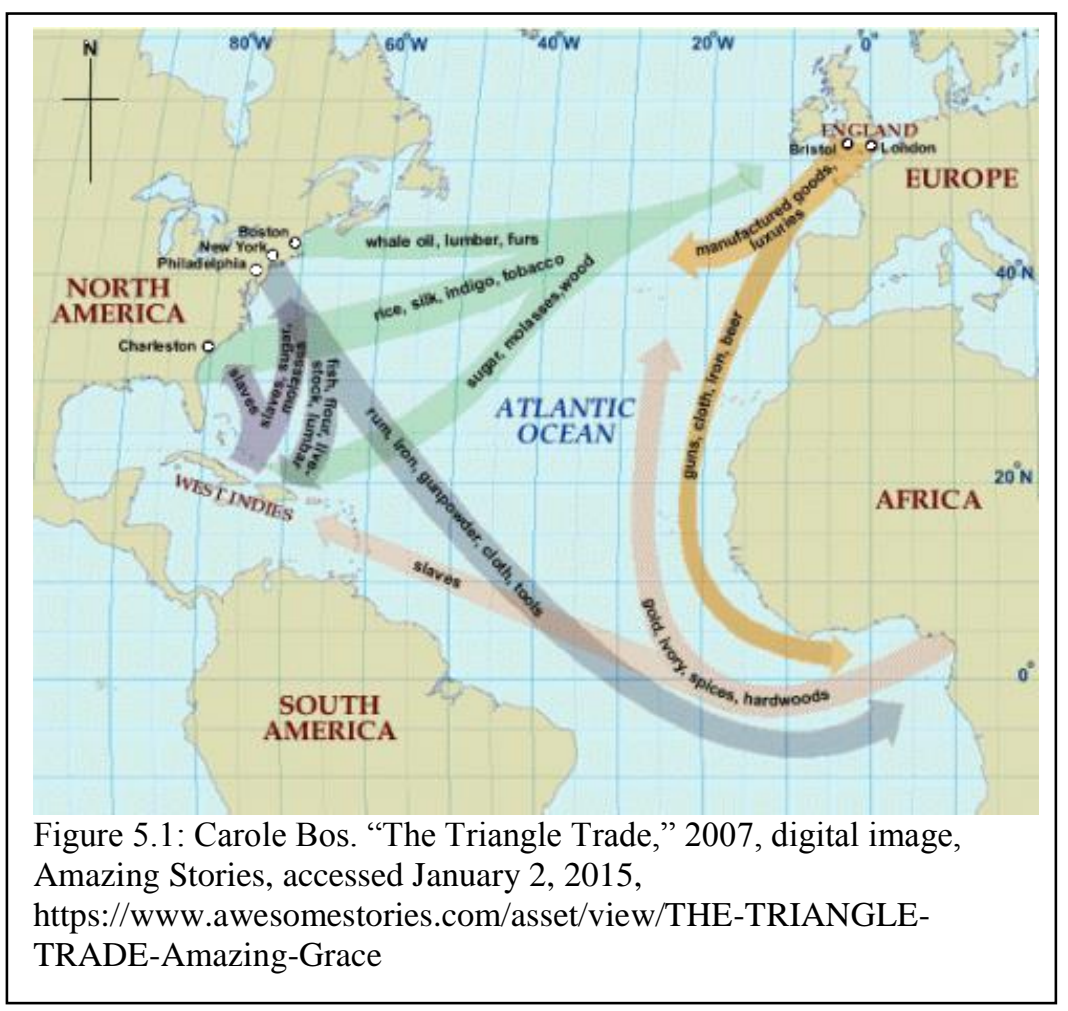

involved created documents related to the thousands of participants who acted as sailors, sellers, merchants, agents, family, and friends. The most famous of these complex systems is known as the triangle trade. The term the triangular trade describes the trade routes going from the Americas to Europe then to Africa and then to back to the Americas (Figure 5.1). ${ }^{202}$

\footnotetext{
${ }^{202}$ Carole Bos, "The Triangle Trade," Amazing Stories, accessed January 2, 2015, https://www.awesomestories.com/asset/view/THE-TRIANGLE-TRADE-Amazing-Grace
} 
There is a hesitation to use this term "triangle trade" as it oversimplifies the way that the slave trade functioned and is felt to be a revisionist's view of the historiography. ${ }^{203}$ The slave trade was a complex economic system that tapped into the global economy, in many ways for the first time. It was also a system that sometimes had benefits beyond the actual sale of human cargos. New England merchants used the slave trade ventures as ways to gain insurance for other endeavors from the European market. It played a large role in key political moves in every country that participated. Most importantly, it shaped the world that we live in today from the genetic makeup of populations to the religious and cultural movements.

To simply describe the slave trade's nature and movement as triangular limits it ranges and makes it harder to understand the trade overall. Assuming a tight relationship between the three legs of the triangle, assumes that all three legs used the same ship. Most of the goods shipped from the West Indies to Europe were shipped on boats specifically designed for that purpose, larger than a typical slaver, these ships were engaged in bilateral trade. ${ }^{204}$ Slave ships leaving the West Indies often didn't take a cargo on. Instead, they either sold the ship in the new world or quickly returned to Europe with just a few crew members and ballast. In the eighteenth century, 65 of 195 slave trade ships owned by the Dutch returned empty. ${ }^{205}$

The slave trade encompasses not just the slaves taken from Africa but also the goods and trade route around the globe that supported the trade. The triangular trade is embedded in the collective memory of today's society as it is a simple way to describe

\footnotetext{
${ }^{203}$ Jay Caughtry, The Notorious Triangle: Rhode Island and the African Slave Trade, 1700-1807 (Philadelphia: Temple University Press, 1981), 5.

${ }^{204}$ Herbert S. Klein, The Atlantic Slave Trade (New York: Cambridge University Press, 2010), 97.

${ }^{205}$ Ibid.
} 
a complex historical event that took place over hundreds of years. ${ }^{206}$ The historic documents from the time and those generated by individuals who experienced or closely witnessed the slave trade tells us another story that is far more complex. Because of this focus on the slave trade as goods being transported, another look must be taken to find information about the vessels doing the actual transportation. The vessels themselves can give evidence to the business mindset, and the profit-driven motives of many of the merchants involved.

These records can tell us if the ship in question was built specifically to go to Africa or if it was refitted to go. They can tell us what measures were taken to convert a ship to go to Africa and what features were built into purpose-built ships to make the journey more profitable in the first place. Log books and letters can tell us what conversions were made mid-journey while crew lists can tell if special labor was needed no board to make these conversions happen. Cargo lists further illustrate what material culture could have been on board and comparing these documents can give insight into the frequency of which specific items were traded on the African coast. Records such as plantation records and Lloyd's ship register tell us the size and type of ships undertaking this journey, and can show trends in ship speed, shape, and size.

It is foolish to think that that in an enterprise as large and complicated as the transatlantic slave trade that there was no ship that was built especially for the slave trade, or that these ships were so exceedingly rare that nothing is known about them. Information about the structure and construction of slaving vessels is gleaned from the archeological and cultural record. Shipwrecks themselves are material culture and can

\footnotetext{
${ }^{206}$ Maurice Halbwachs and Lewis A. Coser, On Collective Memory (Chicago: University of Chicago Press, 1992), 3.
} 
tell a great deal about the construction of ships and their trade routes. For the purpose of this study, the analysis of a shipwreck can be broken down into several categories.

First the structural components of a ship need to be examined. Structural components include deck spacing and configuration of the ship in general, quarters configuration, length and beam of the ship, and the angle of the stern post. The second category is the functional aspects of the ship, features such as port holes, castle, netting, air funnels and slave stoves. The third is features related to specific sailing routes of the ships including the particular configuration and number, the quality of the mast, and the adoption of copper sheathing, planking, and sacrificial planking. Unfortunately due to the many legislative acts aimed at restricting tonnage so as to limit the slave trade, tonnage numbers are often manipulated to accommodate trade vessels and are not always reliable.

Another aspect that must be examined in order to generate a deeper understanding of the structure and construction of slave ships is the measures undertaken to separate crews and cargo from the slaves. These measures include barricades, cargo access and temporary shelving and platforms. The construction of slave ships and the individuals involved are important aspects that historic documents can address. Finally, all slave ship features must be examined together to understand the innate difference between ships purpose built for the trade and those that were converted ships for participation.

In England, hisotric records relating to the slave trade include Plantation Records. These document the coming and going of vessels into and out of port. ${ }^{207}$

\footnotetext{
${ }^{207}$ The Liverpool plantation registers, 1744-1773 and 1779-1784, in the Custom House, Liverpool. Publication No. R96481.
} 
Created by the Navigation Act of 1696, the intention of the Planation Records was to monitor and restrict trade with the colonies (or plantations) to vessels that were registered to British, Irish, or Colonial vessels. ${ }^{208}$ Included planation records are the ship's name, port of origin, master's name, kind or build of the ship, its cargo, the location built and the year, as well as the owner's name. The Liverpool Plantation Records specifically hold information regarding slaving voyages as Liverpool was the largest slaving port in England. The records are in two batches 1744-1773 and from $1779-1784 .^{209}$

Lloyds Register of Ships similarly records details of merchant vessels. Published from 1764-1766 and 1768 -1771, and then annually since 1775 . The earlier registers include information such as the names of the vessels, the name of the master, the number of crew, the number of guns, the names of the owners and when and where the ship was built. They sometimes include any classification given to the $\operatorname{ship}^{210}$. While there is no general index of this register, ships are listed alphabetically. Lloyds Register was not an official register like that which exists currently but more of a record of sea-going vessels entering and exiting royal ports. ${ }^{211}$ This data has significantly contributed The Trans-Atlantic Slave Trade Database. ${ }^{212}$

Other records include family records and merchant records, found in

\footnotetext{
${ }^{208}$ American history Leaflets. Colonial and Constitutional, No. 19-January, 1895. Extracts from the Navigation Acts, 1645-1696 (A. Lovell \& Company, Great Britain 1895). Accessed Feb 12 2013.10. https://archive.org/details/extractsfromnav00britgoog

${ }^{209}$ East Ardsley, Yorkshire, Eng.: E.P. Microfilm, Limited, 1979. British records relating to America 2 reels

${ }^{210}$ Lloyds register of ships online. Accessed 2012 http://www.lr.org/en/research-andinnovation/historical-information/lloyds-register-of-ships-online/ ${ }^{211}$ Ibid.

${ }^{212}$ Stephen D. Behrendt. "Seasonality in the Trans-Atlantic Slave trade," Voyages: The Trans-Atlantic Slave Trade Database. Accessed January 1, 2013 http://www.slavevoyages.org/tast/assessment/essaysseasonality-01.faces.
} 
association with all merchants. Letters, business correspondence, and receipts related to the building and outfitting of vessels, correspondence between captains and agents, agents and owners, and shipwrights and merchants regarding the building, outfitting, and general goings on of a ship can give clues as to each stage of a ship's history. These stages include the construction, loading- unloading, mid-journey transformation, slaves on board, and the return home. In America, Crew Manifests were required of all merchant vessels by federal law beginning in $1789 .^{213}$

Ship plans and ship schematics exist, but this type of document is exceedingly rare. Ships plans and schematics are rare because ship-building knowledge in the early modern period was passed down and not written down. Describing a ship was enough for a shipwright. A shipwright in the Seventeenth and Eighteenth century could build a vessel without the models and plans that would be needed today. Additionally, plans that do exist would be used more as a template than a map to follow, taking the basic angles and measurements, but then making the ship more specific for each buyer.

Arron Lopez was a successful merchant and trader in Newport, Rhode Island. A Portuguese Jew, he arrived in Newport, Rhode Island in Oct. of $1752 .{ }^{214}$ He started buying, selling, and trading in Newport and Providence, but soon expanded into the Atlantic world. ${ }^{215}$ Entering the slave trade in 1767 , he was a conservative trader and made careful preparations for every venture. ${ }^{216}$

When entering the slave trade, he planned on "dispatching vessels to Bristol,

\footnotetext{
${ }^{213}$ Jay Coughtry, The Notorious Triangle, Rhode Island and the African Slave trade 1700-1807 (Philadelphia: Temple University Press, 1981), 56.

${ }^{214}$ Bruce M Bigelow, “Aaron Lopez: Colonial Merchant of Newport," The New England Quarterly 4 (1931): 757.

${ }^{215}$ Ibid., 758.

${ }^{216}$ Ibid., 759.
} 
and then draw bills of exchange... when the vessels actually sailed." ${ }^{217}$ He usually sent out no more than one vessel a year to the Slave Coast, for him a fleet that more than that would represent too much of a gamble. ${ }^{218} \mathrm{He}$ had a part interest or owned outright over thirty vessels. ${ }^{219}$ At least two of these vessels were built and outfitted specifically for the slave trade. ${ }^{220}$ However, diversity was the name of the game for Lopez, and he often sent a wide variety of items across the ocean to make sure that he could get a good return. ${ }^{221}$ With the onset of the American Revolution, many of Lopez's vessels were seized. $^{222}$

Due to his meticulous nature, the surviving collection of documents related to his personal and business life is one of the largest in the world related to the slave trade and is spread over several depositories. Historic documents present evidence toward the uniqueness of the slave ship through several different components.

Documents from around the world show evidence of the uniqueness of the slave trade in different ports, particularly the difference between the Liverpool slave trade and the slave trade in New England. However, the Portuguese and Spanish slave trade also had significant differences, though not explored here in detail.

Historic documents address the structural components of the ship, namely the configuration of the quarters, the length and beam of the ship, and the angle of the

\footnotetext{
${ }^{217}$ Ibid., 760.

${ }^{218}$ Ibid., 771.

${ }^{219}$ Ibid., 772.

${ }^{220}$ Capt. Peleg Clarke \& Fletcher, 6 February 1772, memoir of agreement for sale of a new Brig, Box 52, Folder 4, Sheet 52-187, Aaron Lopez Papers, the Newport Historical Society Library, Newport Historical Society, Newport, Rhode Island.

${ }^{221}$ Capt Clarke from Fletcher, Estimate of Provisions for Guinea Voyage, 24 February 1772, Peleg Clarke Letters 1770-1784, the Newport Historical Society Library, Newport Historical Society, Newport, Rhode Island.

${ }^{222}$ Bruce Bigelow. “Aaron Lopez: Colonial Merchant of Newport," New England Quarterly 4 (1931): 774.
} 
stern post. They also give evidence toward functional components, components related to the routes of the trade and the problems that present to wooden ships in tropical environments. Documents illustrate the roles that crew and cargo played, construction and who is doing it, purpose built versus converted, and mid-journey transformation.

There were many different types of ships involved in the slave trade as this study covers a 300-year range of potential shipwrecks. But the components unique to slavers exist in each. Each country had its own idea of what ships where suitable to go, often aligning with their maritime tradition.

A broad variety of ships plied the slave trade. The Portuguese in conducting the trade between Angola and Brazil in the eighteenth century mainly employed two types of vessels: galleys and corvettes. A law of the year 1684 regulated their carrying capacity to 2.5 and 3.5 slaves per ton, the difference depending upon construction or portholes. Three-masted ships capable of carrying between four hundred and five hundred slaves were the leading type of the Rio trade at the end of the century. ${ }^{223}$

The Portuguese conducted trade along the southern routes of the Atlantic and do seem to be different from those vessels coming out of Western Europe and the Americas. These differences are not as clear as there is not the same availability to Portuguese documents as there are to those in England and the United States. The difference between Liverpool built vessels and American-built vessels is significant. There were specially built ships on both sides of the Atlantic as well as vessels that were repurposed and modified. The traits that each country and economy valued were different, making the ships themselves different. These differences were based on the underlying goal of each voyage and the goals those who financially backed the journey.

\footnotetext{
${ }^{223}$ James Rawley and Stephen D. Benrendt, The Transatlantic Slave Trade (University of Nebraska Press, 2005), 217.
} 
Slave ships built in the style of a Rhode Island slaver were smaller and faster. The dominant thinking was that the most successful journeys were correlated with vessels that quickly crossed Atlantic. The quicker the voyage, the more slaves survived, the more goods traded, the more money could be made. For English merchants, the goal was to transport as many slaves as possible on each crossing to the Americas. This philosophy led English merchants to dispatch larger vessels, and to employee a Doctor on board every vessel, as well as a designated carpenter.

Not all vessels were suited to the African trade. Rhode Island merchants and seaman were specific when they described "a proper vessel for the guinea trade."224 The unique design of the Rhode Island slaver was recognized both at home and abroad. The construction of the Rhode Island slaver, together with the unusual outfit, set it apart from other shipping. It was a unique craft, designed and modified to meet the rigors requirements of a special branch of commerce. As such, it differed significantly from other American and European slavers. These variations were intentional and reflected the trading strategies of Rhode Island's Africa merchants. In 1774, two prospective English buyers commented that a brig belonging to Arron Lopez was "constructed in the manner usual for the trade from Rhode Island to Africa [and] would by no means suit for the trade from Liverpool." 225

Stephen Ayrault, characterized his eighty-ton sloop Fanny as "well calculated for the Guinea Trade" in a notice he placed in the Newport Mercury in the summer of 1774. Throughout the New England Maritime Community, it was generally agreed that Rhode Island slavers were different from vessels that did not carry human

\footnotetext{
${ }^{224}$ Jay Coughtry, The Notorious Triangle, Rhode Island and the African Slave trade 1700-1807 (Philadelphia: Temple University), 70.

${ }^{225}$ Ibid.
} 
cargoes. What makes these vessels different is not described but is extrapolated from

information discussed in pervious sections.

In Liverpool

The shipwreck of the Anna on 27 May 1789, three and a half weeks after she sailed from Liverpool in the command of Captain James Irving, was a significant financial loss for Dawson. Although only a small schooner of 50 tons burthen, it was a "fine new vessel" completed earlier that year in a Liverpool shipyard and register just 17 days before she sailed. In contrast, many Liverpool slave ships were second-hand vessels adapted for the trade and only one quarter were purpose-built. ${ }^{226}$

From a surprisingly early period, Liverpool slips and yards were building ships employed in the slave trade. We have been misled, however, about the size of these vessels. The historian of the rise of the Port of Liverpool, who has written that the Liverpool Merchant of 1700 'might well have measured 190200 tons' and that a slaver of 1724 measuring three hundred tons had a size consistent with that date, blinks the facts. The Liverpool Merchant built in Liverpool in 1724, probably a successor to its namesake and doubtless not significantly smaller than the vessel a quarter of a century earlier, was only weight tons, and it was the next largest of the Liverpool-built ships plying to trade to Virginia until $1732 .^{227}$

The deck spacing and configuration of the ship can be highlighted in documents

related to the commissioning and conversion of vessels. The configuration of the

quarters, the length and beam of the ship and the angle of the stern post can sometimes

be discovered in these types of documents. In a copy of an agreement between Hay

Polock and Cromel Child for the building of the ship Ocean, this is evdient. ${ }^{228}$

That the said ship or vessel shall be built in a manner and form following to with, seventy feet keel, twenty-five feet beam, twelve feet in the lower hold, and four and half feet between decks. All her timber and plank to be white oak, the plank in her bottom to be two inches and one-half thick and three inches at the bulkheads. Two solid walls of five inches along quarter-deck, no bolts in her

\footnotetext{
${ }^{226}$ Suzanne Schwarz, Slave Captain: The Career of James Irving in the Liverpool Slave Trade (Liverpool University Press, 2008), 37.

${ }^{227}$ James Rawley and Stephen D. Benrendt, The Transatlantic Slave Trade: A History (University of Nebraska Press, 2005), 170. .

${ }^{228}$ Hay Polock to Cromwell Child, Box 52, Folder 5, Sheet 52-189, Aaron Lopez Papers, The Newport Historical Society Library, Newport Historical Society, Newport, Rhode Island.
} 
deck plank but bolted and clinched Locust tunnels and everything needful to complete the hull for the seas together with one complete set of masts. Yards and shars as are customary, with anchor stocks and lumber for to build a head and well room.

This letter comes from Warren, Rhode Island, a hub for shipbuilding. While the letter does use the word "customary" as ship building is a trade and not a science. It also highlights the space between decks and the bulk head configuration that was desired by slave ship captains and owners.

The functional aspects of the ship can also be found in these correspondences that outline the building and outfitting of ships. Things like port holes, castle, netting, air funnels and slave stoves needed to be specifically ordered and noted separately. In this description of an English vessel, this is the case.

In construction, the ideal English slave ship at this time was "Long, narrow with a short quarter-deck, no top-gallant forecastle, no gangway and a very low waist." The Ship was built with ports and gratings to conduct air to the human cargo. Moreover, finally, the ship must be "outfitted" for the trade, equipped with shackling irons and nets for throwing around the ships sides when the ship was near land, to prevent escapes. ${ }^{229}$

The outfitting of a ship also included getting supplies for the crew and the slaves. The most important of these supplies was water. While there are many a list of supplies that outline the food and supplies that where needed for such voyages, these supplies rarely survive in the archaeological record.

While a few voyages sailing from Upper Guinea could make a passage to the Americas in three weeks, the average duration from all regions of Africa was just over two months. Casks of water absorbed most of the space on a slave ship". ${ }^{230}$ Newport Feb 61772

\footnotetext{
${ }^{229}$ James Rawley and Stephen D. Benrendt, The transatlantic slave trade (University of Nebraska Press, 2005), 219..

${ }^{230}$ David Eltis, “The Middle Passage," A Brief Overview of the Trans-Atlantic Slave trade (Emory University, 2007) http://www.slavevoyages.org/tast/assessment/essays-intro-06.faces
} 
The barrels of water and food stuffs do not survive in the archaeological record. What does survive, are the barrel stays. Ships often brought extra barrel stays in case an opportunity arose that would allow a ship to re-supply with water.

The most compelling evidence supporting the idea that some ships were built specifically to go to Africa and trade in slaves are the commissioning documents for these vessels. Common among ship builders and vessel owners, these were ways to describe what was desired. Often this was done by making comparisons to other vessels. In memoir of agreement with Capt. Peleg Clark for the building of a new brig, drew a comparison to the Brig Hannah.

A double deck new brig about one hundred of thirteen from burthen to be delivered by the shipbuilder to Capt. Peleg Clarke by all month of April next finished for the Africa trade. Rigged and equipped with such number of sails as the brig Hannah was, when commanded by Capt. Nathaniel Briggs on a voyage to the coast.

To be sheathed with inch pine boards or half in Cedar fur cables to be the best bower eighty fathom, nine and a half inches, a howfer one hundred and seventy fathom, six inches, the anchors in proportion.

There is also to be a yacod about eighteen foot long; the brig to have gratings and airports as it is usual in a Guineaman, \& to be painted in a plain manner.

Then arriving a second boat, caboore, colors, small arms, chain and handcuffs with every other small utensil to be excluded and provided by Capt. Clarke

The subscribe engages to deliver the above-described vessel for the coordination of six hundred and fifty sterling, payable by said Capt. Clark in bills of his own drawing on London at thirty days sight the bills to be compleated at parr say at for shillings, and six pence sterling-dollar and to be, delivered to the subscribed hereof at the signing of the memorandum if reigned." 231

This agreement also highlights the well thought out plans and functional needs

\footnotetext{
${ }^{231}$ Capt. Peleg Clarke \& Fletcher, 6 February 1772, memoir of agreement for sale of a new Brig, Box 52, Folder 4, Sheet 52-187, Aaron Lopez Papers, the Newport Historical Society Library, Newport Historical Society, Newport, Rhode Island.
} 
of a slave ship. Extra sheathing for the risks that sailing in tropical waters presents to hull. Gratings and airports for the captive cargo, as well as the needed cuffs, small arms and utensils (i.e. spoons) necessary for a voyage. This particular document also highlights the small community that is Rhode Island slaving as the Hannah was not owned by Lopez the owner of this vessel.

The same can be said of vessels being rebuilt for the slave trade. The Childs family was involved in many aspects of slave ship outfitting in New England, in some cases their services where used exclusively. In this agreement with Cromwell Caleb Childs, he is sought after to add an upper deck to the sloop Industry so that the ship was the right size and decked correctly to go to Africa.

It is hereby agreed between Cromwell Caleb child of Warren shipwrights of the one part and Arron Lopez of Newport merchant \& owner of a certain vessel or sloop called the industry now in the harbor of Newport... agrees to build a new upper deck on said vessel to run flush for $\&$ aft they are also to run the lower deck flush aft, to given her one wale and one black strike of a side the timbers to run down as far as possible below the wall. The height between decks to be four foot. ${ }^{232}$

Also included in this document is the desire for the builders to add extra after hatches and to add under the bowsprit a hook and knee, in addition to making the main hatches in the lower deck. All of these traits made the vessel more desirable as a slaver. The deck height in particular, " $4 \mathrm{ft}$ " would allow for the storage of cargo below deck as well as space for the crew. The hook and knee instead of a traditional figure head was common as it is saved money and made the ship less recognizable. The main hatches on the lower deck were a more secure way of stowing cargo and extra hatches increased air flow below decks and made the movement of cargo easier.

\footnotetext{
${ }^{232}$ Cromwell Caleb Childs to Aaron Lopez, 22 September 1772, agreement to fit an upper deck on the Sloop Industry, Box 52, Folder 4, Sheet 52-172, Aaron Lopez Papers, the Newport Historical Society Library, Newport Historical Society. Newport, Rhode Island.
} 
Features and considerations related to the navigation routes that ships took are also evident in these documents. Like the before mentioned sheathing, other shipboard features were determined by the routes taken across the Atlantic. These included the configuration of the sails and the number of sails, the quality of the mast, as well as the adoption of copper sheathing, planking, and sacrificial planking. A consideration of tonnage is also important. Unfortunately, due to the many legislative acts aimed at restricting tonnage so as to restrict the slave trade there was often manipulation of records to make trade appear more legal or as some speculate to make financial loss seem greater should a ship be lost.

With no docking or maintenance facilities on the African coast, ship owners added other features. An important part of outfitting a vessel was to include smaller boats on board the ship, these small vessels are used to go ashore and up river. These boats were responsible for on loading and offloading cargo. ${ }^{233}$ These small boats were a ship's life line and captains often felt it important to have them before leaving for the African coast. Part of this logic was the fear that wood could be hard to come by once in Africa. Any damage to the ship could be catastrophic, as could be the running down of the firewood supply. Following this logic, merchants required the mast of a slaver to be of the highest quality. "A broken mast was not easily replaced on the coast of Africa and could spell ruin for a voyage. ${ }^{234 "}$ Any additional timber needed to be loaded and stowed beforehand as it was unlikely any would be found on route.

The lack of available wood and its expense may also be the reason why slavers adopted copper sheathing earlier than nearly every maritime industry. Copper

\footnotetext{
233 Jay Coughtry, The Notorious Triangle, Rhode Island and the African slave trade 1700-1807 (Philadelphia, Temple University Press, 1981), 63.

${ }^{234}$ Marcus Rediker, The Slave Ship; A Human History (New York: Penguin, 2007).
} 
sheathing protected hulls from boring tropical worms and mollusks that live in the warm waters of the coast of Africa and in the Caribbean, thus prolonging the life of a ship. While there are records of copper sheathing used as early as the 1720 's by the Royal African Company it did not become common place until later. ${ }^{235}$ "In the last quarter of the century of the slave trade, from 1783 to 1808 , one of the features most commonly emphasized in the sale of any given ship was its copper bottom."236 This feature was often noted in personal correspondence. In a letter from Liverpool in August of 1791 the ship Carnatic was mentioned as having been "launched from a slip near the kings dock...she is sheathed upon the new principle of coppering - the sheets being all wrought cold, instead of the usual mode by fire, from which great advantages are expected."237

Long routes and time at sea with potentailly hostile cargo was another factor to be considered in the building and out fiting of a slaver. Measures that separated crews and cargo were particularly important both for the mortality rates but also in cases of insurrection. These measures include barricades, cargo access and temporary shelving and platforms. Rearranging of the deck for food distribution and limited access to the armory where all completely necessary modifications.

The feature common to all slave ships, regardless of nationality, was the area "between decks," where the slaves were carried. On a regular commercial vessel, this passageway, situated on the main deck and the hold, was little more than a crawl space, two - or three-feet high. To accommodate the slaves on a slaver, the between decks area was often four or five feet high. This type of construction maximized the available space on a vessel and segregated the human cargo from the crew above and the supplies below. The capacity of the slave quarters was increased further by the construction of platforms midway between the deck and the overhead. These platforms extended out of the

\footnotetext{
${ }^{235}$ Ibid., 371 .

${ }^{236}$ Ibid., 71.

${ }^{237}$ Marcus Rediker, The Slave Ship, A Human History (New York: Penguin, 2007), 375.
} 
bulkhead on all sides of the vessel, and were about six feet long, or just long enough to accommodate a prone human being. .... a person entering a the slave quarters through a single hatch on the main deck was confronted with a narrow corridor, on either side of which were tow rows of slaves, either lying down or squatting, one group on the deck and the other a few feet above them on the wooden platforms. ${ }^{238}$

Whether this configuration was designed with the idea of space or health in mind is unclear. What is clear is that the air ventilation was important regardless of the nationality of the vessel. Plans of slavers show two types of hatchways: large ones, which offered more air to slaves and probably increased their survival rate, and small one, which protected the vessel from waves entering the hull and increased the control of slaves by limiting their movement from hull to deck. Thus, a simple thing like the size of the hatchways reflected whether the ship's owner gave higher priority to the health requirements of the slave or the survival of the vessel. ${ }^{239}$

After the decision was made to have a ship built for the slave trade, the owner then needed to decide who was going to build it and where. This decision was largely based on cost, and global politics surrounding wood and slave trade enforcement. Different ports were popular at different times for several reasons. These reasons included the availability of labor, lumber, and trends in shipbuilding. Sometimes these descriptions were very vague.The "Ten Gentlemen", a group of merchants in the Netherlands described the ships they wanted to be built in a letter to the builders as thus "build another nine frigates into slave ships according to the specifications of the ship Leusden." ${ }^{240}$ However, with no written descripition of the specificiations for the

\footnotetext{
${ }^{238}$ Ibid.

${ }^{239}$ Junius P. Rodriguez, The Historical Encyclopedia of World Slavery Volume 1-7 (Santa Barbara: ABC-CLIO, 1997).

${ }^{240}$ Leo Balai, Slave Ship Leusden: A Story of Mutiny, Shipwreck, and Murder (Norwich: UTS

Publishing. 2014), Location 562.
} 
Leusden it is nearly imposibble to understand what these mechants where refering to with out examining the archaeolgoical record.

The location where a ship was construced and by whom was most influenced by the cost of lumber. During the eighteenth century, the average lifespan of a wooden ship was approximately 12 years. The most common wood used in the construction of British ships was oak and the building of a ship usually required about twice as many tons of oak as the tonnage of cargo the ship could carry. ${ }^{241}$ Merchants were extremely fical and would often import different materials based on where they could be obtained for the cheapest, or would simply have the ship built at that location. The timber market affected the entire world of maritime commerce. The lack of timber in the old world was largely responsible for shifting the shipbuilding capitol from England to New England and the Americas. Like all markets the world of shipbuilding became a small committee of builders, suppliers, and specialty laborers.

Particularly in Rhode Island, there was a sense of loyalty among builders. The same merchants use the same builders and carpenters over and again, in some cases almost exclusively. This was the case with Jeremiah Childs. Childs was a ship chalkier in Newport Rhode Island. It seems that people involved in the slave trade at a high level used Childs services exclusively, returning to him again and again from 1791 to 1815. ${ }^{242}$ This included the D'Wolf family and the Champlin's. ${ }^{243}$

In Liverpool this was not the case. A larger pool of merchants at a larger port made slave shipping and ship building more of a free market enterprise.

\footnotetext{
${ }^{241}$ Paul Warde, "Fear of wood shortage and the reality of woodland Europe, 1450-1850," Historical Workshop Journal 62 (2006):40.

242 Jeremiah Jr Childs., Account Book, 1790-1815, the Rhode Island Historic Society Library and Archives, the Rhode Island Historic Society, Providence, Rhode Island.

${ }^{243}$ Ibid.
} 
Writing in 1792, Holt provided a little more detail of the shipbuilding industry. He noted the existence of nine shipbuilding and three boat-building yards, adding that there had been a ten-fold increase in the rents of the Corporation landlord over the preceding 30 years. He also claimed that about 30 vessels were built each year, the most common size being 300 tons, and a special feature being the lodging of slaves for African vessels'. Evidence relating to eighteenthcentury merchant shipbuilding is extremely scare, but a rare example emerges from the letter book of the slave trader Robert Bostock. In December 1791 he refers to the construction of his new ship, a large vessel capable of holding 210 slaves and built in Quick's yard. Other sources suggest quite extensive shipbuilding activity that compared favorably with the major output of the east coast ports." 244

Shipbuilding in Liverpool expanded rapidly and was the site of widespread shipbuilding specifically for the slave trade. While Liverpool and Bristol merchants may not have been using specific tradesman exclusively, the building of ships in these ports was a staple in the economy. A Bristol man visiting Liverpool illustrated the depth with ship building and the slave trade penetrated the people in these communities by noting in 1773 how in 'Liverpool people go on with such a spirit'. He also commented that Liverpool had a "plentiful supply of ships for the slave trade." 245 There is next to no information as to where the builders in Liverpool where getting their timber, but it could be determined archaeologically if more wood samples were collected from slave ships as they are discovered.

In the 1790s, the author of a series of pamphlets which discussed the Deficiencies of London's ports with other English ports stated that 'Liverpool owes everything to its docks and spirit of enterprise', suggesting that everyone in the community was involved in some way. Yet this community involvement did not seem to be as encompassing or as recurrent in Newport, Rhode Island. Instead, the market

\footnotetext{
${ }^{244}$ David Richardson, Anthony Tibbles, \& Suzanne Schwarz. Liverpool and Transatlantic Slavery, (Cambridge, Liverpool University Press 2007), 241.

${ }^{245}$ Ibid., 129.
} 
in Liverpool acted much more along traditional market principals, possibly because everyone was involved in the slave trade and competition was created. Gerrard Backhouse, for example, had enough experience to be a slave ship captain, but failed to make that rank. B etween 1773 and 1789 he made eight slaving voyages, the last three aboard the 200-ton Betty, newly built at Lancaster, in which he had shares. ${ }^{246}$ But because he had worked form several different owners and there was an abundance of experinced sailors he was not yet a captin.

Rhode Island vessels had minimal crews while English vessels have a large crews. This follows the economic principals of both slave trade markets. English crews almost always had a Doctor or surgeon on board, and more importantly to the structural changes of the ship a designated carpenter.

Slaving ventures could not proceed without well-paid carpenters who converted sailing vessels into temporary Guineamen. Once ships departed England, they began to modify interiors to maximize space to imprison enslaved Africans. They built Bulkheads and roundhouses to create 'apartments' to separate enslaved African men, boys, and females. Roomy cabins for officers and passengers became crowded prisons for African woman and children. Before arriving on the African coast, they constructed a 6-8 foot wood and iron barricade, extending above the deck, to separate African men from women and give officers abaft a greater defensible position during insurrections. ${ }^{247}$

Liverpool's docks were the center of flourishing shipbuilding and the slave trade was readily supplied by such vessels. Liverpool was the place of build for 2,120 of the 8,087 ships (26 percent) engaged in the British slave trade between 1701 and 1810. By Contrast, 541 slave vessels were constructed in the same period in London and Bristol, a shade under a quarter of the Liverpool total. In addition, 1742 of 2120 Liverpoolbuilt ships used for slaving voyages ( 82 per cent) were constructed in the second half

\footnotetext{
${ }^{246}$ Ibid., 129.
}

${ }^{247}$ Ibid., 93. 
of the eighteenth century, when Liverpool dominated the British ports in the slave trade. Some ships were purpose-built for transatlantic slaving. However, this was almost certainly not true of most vessels in the trade. Over three-quarters of the ships used in the eighteenth-century British slave trade were second-hand, and it is likely that many slaving vessels dispatched from Liverpool had previously been deployed in direct trades across the Atlantic. ${ }^{248}$

Another slave-ship captain, William Sherwood, was asked whether the construction and "conveniences" of a ship were not more important than confining the number of slaves to a certain tonnage. In response he said 'I think the construction is more material that the tonnage; in a long narrow ship the air circulates more freely: a short quarter-deck, no topgallant forecastle, no gangway and a very low waist, are circumstances of greater advantage than a mere extension of tonnage. 249

In the construction, the ideal English slave ship at this time was "Long, narrow with a short quarter-deck, no top-gallant forecastle, no gangway and a very low waist." The ship was built with ports and gratings to conduct air to the human cargo. Finally, the ship was "outfitted" for the trade, equipped with shackling irons and nets for throwing around the ships sides when the ship was a near land, to prevent escapes. ${ }^{250}$ William Sherwood's comments on the needs for air flow and speed as more important than tonnage suggest two things. First, he was likely operating toward to latter half of the Eighteenth century. Second, that Sherwood was operating under the assumption that more money could be made the longer slaves lived, not the more slaves were packed on board.

Whether a ship was built in the Americas or built in England, there where ships

\footnotetext{
${ }^{248}$ Ibid., 19.

${ }^{249}$ James Rawley and Stephen D. Benrendt, The Transatlantic Slave Trade (University of Nebraska Press, 2005), 253.

${ }^{250}$ Ibid., 219.
} 
that were built specifically for the slave trade, even if this was only the case with a third of the vessels trading in Africa. The evidence for these ships in the archaeological record is hard to come by but in the historic record is abundant. In the case of Arron Lopez, alone he commissions at least five ships to be built from 1773 to 1764, all of which would participate in the slave trade for at least one voyage. These ships were built to specifications determined by the ship builder with references to other slave ships that had been successful. This was the case in an agreement with Silas Casey and John Gleason in Aug 26, 1773 with Arron Lopez for building a ship. ${ }^{251}$ Similar agreements are outlined between Lyhster Childs of Warren and Aaron Lopez of Newport in an agreement dated 38 Dec 1774, ${ }^{252}$ in a May 1764 agreement to build a brig between Bowens and Lopez, ${ }^{253}$ and an agreement dated 1764 between Abiel Chase and Lopez for the building and delivery of a new ship. ${ }^{254}$ The details in these agreements are generally as follows:

Said child engages to build for said Lopez on the part the half afoned a good substantial double decked ship of the dimensions following and in a mannerfrom now onlist. Seventy-two feet keel twenty-six feet beam, twelve and a half feet lower hold and four foot six inches between decks'...'plank to be all three inches thick', lower deck planks 2 and 1/2 inches

Her trunnells to be of locust wood and her thon to be the best from Philadelphia to have a knee fixed under the bowsprit instead of a head, her main mast not to be placed so far forward as is customary, her main mast to be fixed much further aft (in proportion) than the ship Nancy's but have a fair round side and no means

\footnotetext{
${ }^{251}$ Silas Casey \& John Gleslen to Arron Lopez, agreement for building a ship, 26 August 1773, Box 52, Folder 4, Sheet 52-177, Arron Lopez Papers, the Newport Historical Society Library, Newport Historical Society, Newport, Rhode Island.

${ }^{252}$ Lyhster to Childs, Articles of agreement for a ship, 28 December 1774, Box 52, Folder 4, Sheet 52 181, Arron Lopez Papers, the Newport Historical Society Library, Newport Historical Society. Newport, Rhode Island.

${ }^{253}$ Bowens to Lopez, May 1764, Agreement to Build a Brig, , Box 52, Folder 4, Sheet 52-143, Arron Lopez Papers, The Newport Historical Society Library, Newport Historical Society, Newport, Rhode Island

${ }^{254}$ David Sopeff, Enoch Lyson and Arron Lopez, 1764, Articles of Agreement to deliver a ship built by Abiel Chase. Box 52, Folder 4, Sheet 52-147, Arron Lopez Papers, the Newport Historical Society Library, Newport Historical Society, Newport, Rhode Island.
} 
to have a quick shear of aft.

With a thout shear, the plank for her waist to the extremely well-seasoned not less than six inches and a half in breadth or more.

The seams in the steep to be as small as possible

Her gunwales or waist, above the second deck to be eighteen inches deep her floor timber to be full fifteen feet long and 16 inches dead

While the ship was important, so was the timing of the voyages. It was imperative that ships leave at a time they would not get caught in too many storms, arrive so that they would not get trapped on the coast of Africa and leave the west coast so that their journey across the Atlantic would not be too delayed with living cargo on board. This meant that ships being built needed to be delivered fully outfitted and on time. Arron Lopez was particularly keen on this. In an article of agreement he states specifically that: "said child also engages to do all his work for the hull of said ship and deliver her afloat at Warren afore said finished in the middle of August." It was not always possible or practical to have a ship built; instead shipwrights on both sides of the Atlantic would convert vessels to fill the needs of merchants. This meant adding simple additions like air ports or extra sails to extreme modifications like adding another deck or more bulk heads. While much of the experimentation in ship design occurred on ships being built, features that were thought to work where adopted onto converted ships.

Because of the nature of ship building in New England there are a few examples in the historic record of commissioned ship modifications. Second hand ships were converted for many purposes so it can be difficult to make out what conversions were for what purpose and which trade. In a single document between Lopez and Barney \& Hill, in August of 1761, there wass a request to add decks to two 
single decked sloops. ${ }^{255}$ Merchants he later wrote to about the building of the slave ship Sally. ${ }^{256}$ Many of these documents can look the same; as documents addressing the maintenance and repair of vessels, meaning that they were simple receipts of payment with little to no detail.

When the British navy was hunting slavers after the Napoleonic Wars, vessels engaged in the slave trade had to be crafted with speed as the main requirement. ${ }^{257}$ Slave ships needed to be fast to transport enslaved people across the Atlantic with minimal loss while being armed sufficiently to protect their valuable cargo. Slavers provided relative speed and power plus the ability to carry, feed and conceal a large number of men. This and the fact that the open main deck was a good fighting platform made slave ships particularly desirable vessels to capture and use by pirates. $^{258}$

The slavers also had to be simply and cheaply built to minimize the owner's financial loss if captured. ${ }^{259}$ In the lead up to the abolishment of the slave trade, it was often to expensive to build a ship so many ships where re-purposed for the journey. After the abolition, the profit margin of a successful voyage was so high that whether a ship was purpose built or converted hardly mattered, a ship could be abandon after the journey and the owners would still make a large profit. The fast and sleek ships

\footnotetext{
${ }^{255}$ Lopez to Barney and Hill, 5 August 1761, For the Building of two single deck Sloops, Box 52, Folder 4, Sheet 52-139, Arron Lopez Papers, the Newport Historical Society Library, Newport Historical Society. Newport, Rhode Island.

${ }^{256}$ Arron Lopez to Richard Thomas, 7 September 1763, Letter regarding the building of the Sally, Box 52, Folder 4, Sheet 52-141, Arron Lopez Papers, the Newport Historical Society Library, Newport Historical Society, Newport, Rhode Island.

${ }^{257}$ Junius P. Rodriguez, "Shipping," The Historical Encyclopedia of World Slavery Volume 1-7 (Santa Barbara: ABC-CLIO, 1997).

${ }^{258}$ Marcus Rediker, The Slave Ship A Human History (New York: Penguin, 2007), 8.

${ }^{259}$ Junius P. Rodriguez, "Shipbuilding," The Historical Encyclopedia of World Slavery Volume 1-7 (Santa Barbara: ABC-CLIO, 1997).
} 
being built and converted had only two requirements, to make money and to make it past the British Royal Navy.

Regardless of whether a slave ship was purpose built or converted to a slave ship these ships functioned differently on different legs of its journey. Because of this, the ship would undergo a transformation in the middle of its journey. This transformation would either take place on the journey to the African coast or once it arrived there and the cargo was of loaded. Similarly, a transformation would occur again once slaves and cargo had been off loaded at their intended destination. The modifications were performed by different people depending on the nationality of the ship. American vessels employed there whole crew in the labor with the captain acting as director, English vessels generally had a designated carpenter to do the labor who pulled other crew as needed.

An excellent example of this mid-journey transformation is evident in the log of the Mampockata. held at the National Museum of Liverpool's maritime archives. ${ }^{260}$ The Mampockata was a square sterned brigantine with a round poop-deck. It was weighted and sound for four guns. She was lost in 1793 after being captured by the Americans in 1782. She was refitted in 1786 for the slave trade, making her tenure as a slaver rather short and her uses before then unclear. In the log related to the brigantine there are several entries that describe the work that she underwent both before the journey and as the journey progressed.

Refitted for the slave trade beginning in 1786

\footnotetext{
${ }^{260}$ The Log of the Mampockata, Liverpool Slave Trade Collection, DX/2277, Maritime Archives and Library, Merseyside Maritime Museum, Liverpool, England.
} 
4th of Sept 1786- building quarter deck 28ht of Feb 1787- repairs

29th of Aug 1787 building of the quarter-deck

21st of Sept. 1787- building of barricade 28th of Nov. 1787- Ivory received 20th of Feb. 1788- breaking up on the quarter-deck

The log shows that features of the ship changed as the ship sailed and changed again once the ship was off loaded of its human cargo. This evidence suggests that the quarter deck was put into place when slaves were on board and taken down when they were not on board, as does the note that the barricade was put up.

Another mid-journey change is that to the sails. Again there are few examples that survive in the archaeological record, but especially once the trade was deemed illegal

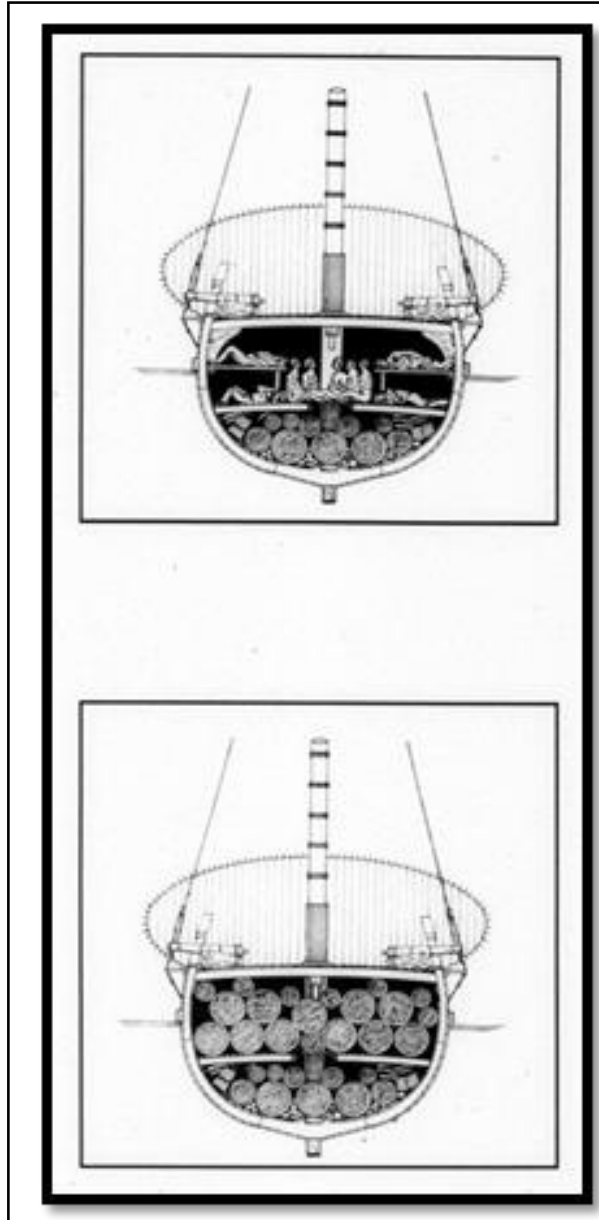

Figure 5.2: A cross-section of the slave ship the Henrietta Marie. 1995, Line Drawing, in Bill Muir \& Frank Besse, $A$ Slave ship Speaks: The Wreck of the Henrietta Marie (Key West, Florida: Mel Fisher Maritime Heritage Society, 1995). historic sources suggest that ships carried extra sails. This could be to achieve one of two things, first that ships built for speed where built with more sails in mind; second that extra sails where deployed to push air below decks. Wind sails, were used on some ships, especially the larger ones to improve the health of those held below decks by increasing ventilation. ${ }^{261} \mathrm{~A}$ wind sail is a funnel tube made of canvas attached to the bottom of the hatch. Later the funnels transitioned to directed square and triangular

\footnotetext{
${ }^{261}$ Marcus Rediker, The Slave Ship A Human History (New York: Penguin, 2007), 71.
} 
sails rather than specifically attached canvas air tubes. The circular sails open at the base, were intended to "convey a stream of fresh air downward into lower apartments of a ship."262 Originally intend to help sailors on large man of war; they were converted for this purpose. The square and triangular sails used later could easily be pulled up or down to conceal their purpose.

The tons burthen a ship could carry does not actually come from a measurement of weight, but rather from the number of 'tuns', or large barrels a ship could carry. This measurement varied across time and geographical region but in the eighteenth century the formula used for calculating the tonnage of slave ship was keel length $\mathrm{X}$ inside beam depth of hold/94. ${ }^{263}$ Tons a ship could carry directly impacted the number of slaves a ship could carry, and the evaluation of those tons become very important after the Doblen Act. Tons is a feature that would appear to lend itself to a pattern in these vessels thus tonnage cannot be trusted. There is too much variation in type of vessel, but also there are examples such as the Liverpool Merchant. This vessel was listed at 190-200 and then later on as 300, changing to suit the law, the port or the insurer $^{264}$.

There is still much work to be done in this field and on this subject. According to the trans-Atlantic slave trade voyage database 825 ships where lost while in transit from Africa. Of those only three have been discovered. This means that not only are there still a significant number of vessels that are waiting to be discovered, but that there is much more that can be learned about the type of vessel at the heart of the

\footnotetext{
${ }^{262}$ William Burney, New Universal Dictionary of the Marine, 1815 (Annapolis: US Naval Institute Press, 2006), 38.

${ }^{263}$ O. Reiss, Blacks in Colonial America (North Carolina: McFarland \& Company, 1997), 206.

${ }^{264}$ Voyages Database, The Trans-Atlantic Slave Trade Database (Emory University, 2009). Accessed June 2013. http://www.slavevoyages.org/tast/database/search.faces
} 
trade. 


\section{CHAPTER 6}

\section{EXAMIN THE ART}

The emotional intensity that surrounds the slave trade drove many to produce works of art addressing what they had witnessed. In the early days of the slave trade, explorers drew images to portray new and foreign lands and to share their experience with the people who were at home. During the height of the slave trade, graphic representations continued but some of the artwork was produced by people who were against the slave trade. As the abolitionist movement took off and the slave trade was outlawed, art was used to show the public the deplorable conditions of slavers and to glorify the Royal Navy vessels that now had the challenge of capturing ships still

participating in a trade they deemed immoral. When looking at the paintings related to slave ships there are several things to examine when determining what is true and what falls under artistic license.

The first is decoration. As discussed earlier, in relation to the letters from Arron Lopez, decoration kept to a minimum on most vessels. Slave ships were money making endeavors; extra expenses such as exterior decorations, were superfluous. Keeping decorations and extras to a minimum also reduced losses if the vessel was captured or sank. The questions to ask are as follows: Is there a figurehead and what does it look like? Does it make sense to have decoration on a ship that is meant to make money and possibly be disposable? Does the ship appearance draw attention to it? Why? How much is an artistic rendering and how much is what the ship truly 
looked like? Questions should also address the use of color. What colors were used and where are they in the composition?

The next step is to look at the historiography of the painting and what the painting is? What ship is the painting supposed to be? Does it match? Did that ship actually participate in the slave trade? Does it matter? Does it fit in with the timeline of the actual ship?

Finally, what is in the actual image? Is it a plan view or a cut away? What is visible and what should be visible? Are there portholes, sails, barricades and other

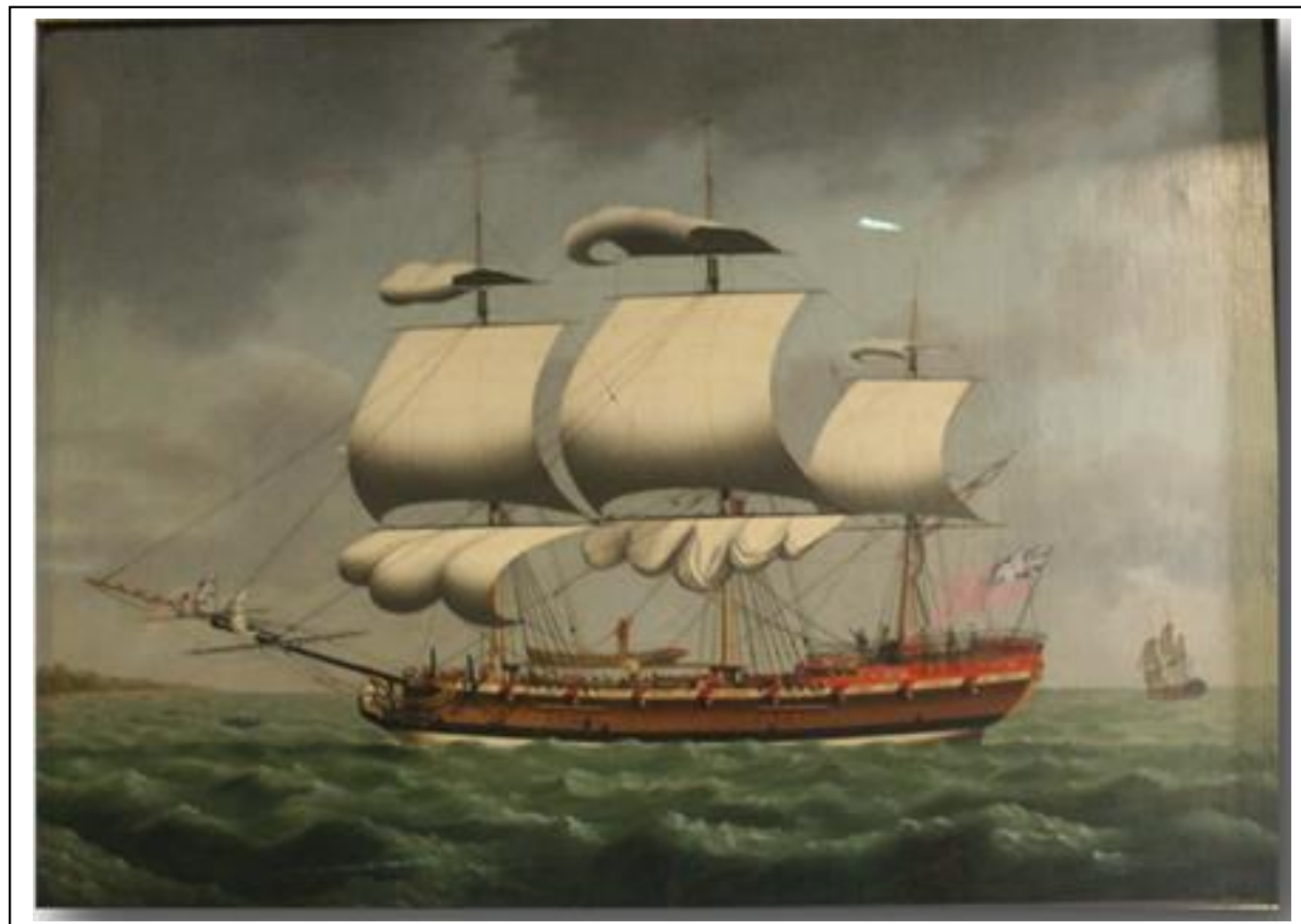

Figure 6.1: William Jackson, A Liverpool Slave Ship, 1780. Oil on Canvas, 102cm x $127 \mathrm{~cm}$, Merseyside Museum, Liverpool UK.

items that would be unique to a slave ship or features that would be beneficial to its purpose? What is missing? How many decks, sails, and what kind of a vessel is it? The most well-known rendering is 'A Liverpool Slave Ship'. Painted 1780 by 
William Jackson and housed in the Merseyside Maritime Museum in Liverpool, England, this is one of the most recognized images of a slave ship. ${ }^{265}$ Jackson shows a three-masted, 16-gun ship of unknown name or origin. It has two decks and is viewed in port profile. In the distance is another rendering of the same vessel shown in portquarter view.

The first deck is the gun deck as noted by the open gun ports. The second deck is visible because of the lower portholes that would be used to circulate air to the lower cargo deck. The raised deck at the stern with railing shows a defensible position in case of an insurrection. Features such as a barricade and netting are missing which means that this is most likely a rendering of the ship when no slaves are on board. The colors seem to be slightly exaggerated, in that there is a red highlight to the image. While the low black band and the white lower hull are consistent with other descriptions and images the red paint seams too decorative. There would be no need for red railings or to paint the interior of the gun ports with any color other than that which the rest of the ship is treated with. Red would be an unneeded expense and reserved for other vessels with longer life spans or higher budget, like naval vessels. ${ }^{266}$

\footnotetext{
${ }^{265}$ William Jackson, A Liverpool Slave Ship, 1780. Oil on Canvas, 102cm x $127 \mathrm{~cm}$, Merseyside Museum, Liverpool UK.

${ }^{266}$ Ibid..
} 
The small boat that is pictured raised slightly above the deck is also of particular interest, this is a shoring vessel. A shoring boat would be used to carry cargo back and forth from shore. Not often depicted, these boats where seperatily being commissioned by

owners to go

aboard ships. The

common

perception is that

shoring vessels

were available at

port, though this

was not always

true, many times

ships making port

needed to be

entirely self

sufficent and

would need shoring

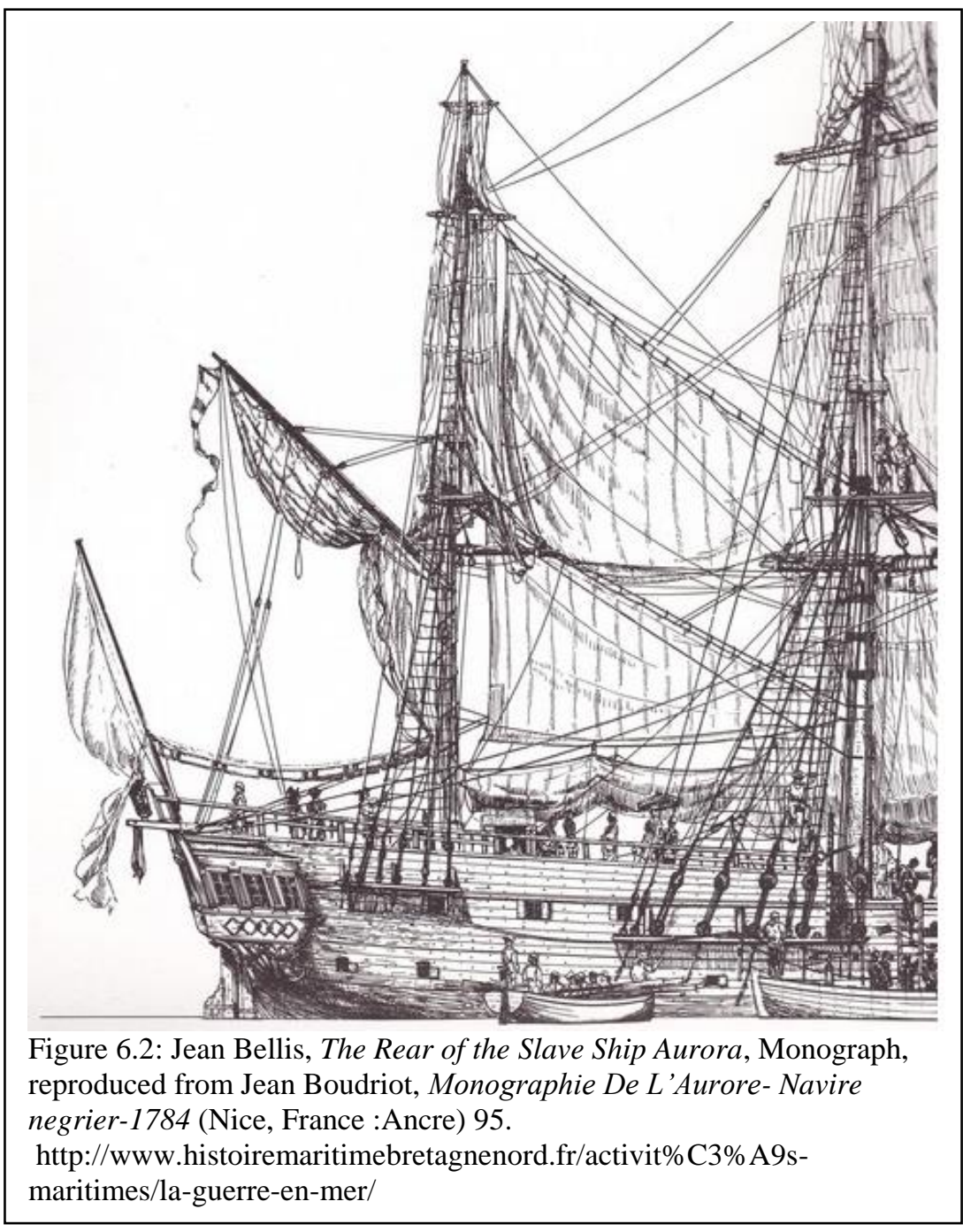

boats of there own to conduct buisness and to make sure cargo paid for actually made it aboard. ${ }^{267}$ Another feature of this painting that gives clues as to the location of the ship is difficult to make out. In the distance there are two other vessels coming from the shore with what looks like slave rowers standing up suggesting that this boat is

\footnotetext{
${ }^{267}$ Bowens to Lopez, May 1764, Agreement to Build a Brig, , Box 52, Folder 4, Sheet 52-143, Arron Lopez Papers, The Newport Historical Society Library, Newport Historical Society, Newport, Rhode Island.
} 
sitting on the coast of Africa. ${ }^{268}$

Like in "A Liverpool slave ship" the feature that most often distinguishes a merchant ship as being a slaver to scholars today, is the presence of small hatches on the lower deck to ventilate the cargo space. In French ships, these portholes are called suckers. ${ }^{269}$ In the lithograph

"The rear of the slave ship Aurora" (Figure

6.2) these

"suckers" are plain to see.

They are below

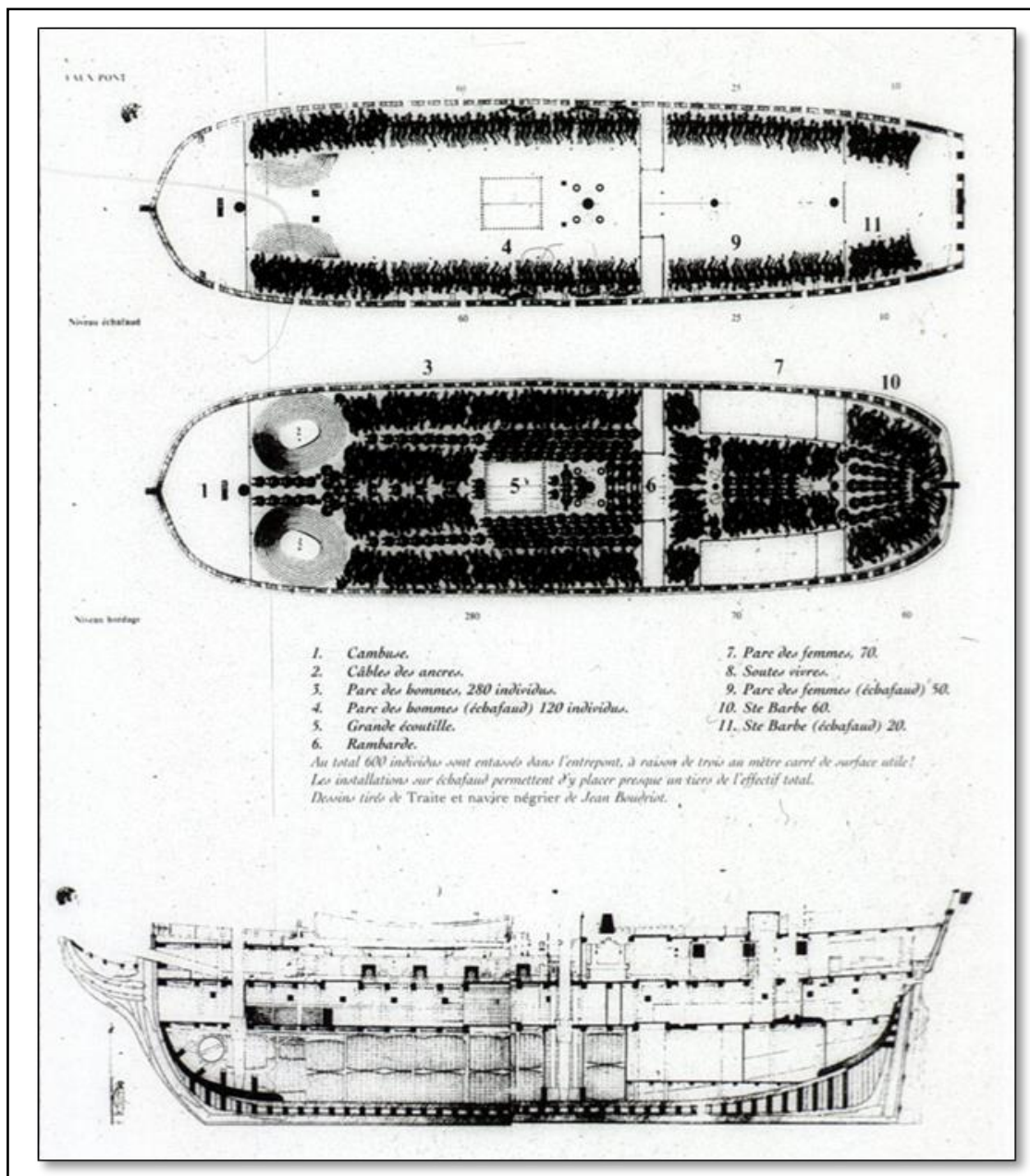

Figure 6.3: Jean Bourdriot, Arora Monogrpah, monograph, reproduced from , reproduced from Jean Boudriot, Monographie De L'Aurore- Navire negrier1784 (Nice, France :Ancre) 95.

the gun deck and near the water line. On this vessel, the portholes have hatches,

serving as both a security measure and a means to keep the vessel watertight.

This image only gives a view of the rear of the ship, the elevated stern castle is

268 “ ‘A Liverpool Slave Ship’ about 1780 by William Jackson (active about 1770-1803)” International Slavery Museum, accessed Jan. 10, 2013, http://www.liverpoolmuseums.org.uk/ism/collections/middle_passage/slave_ship.aspx ${ }^{269}$ Maritime History of Northern Britain, "The War at Sea: On September 2, 1795, the sinking of the former slaver 'national assembly' in the north of the island of Er," Accessed Feb 2013. 
in clear view, and the close up of both the gun deck hatches and the windows of the captain's cabin suggest that this vessel, like others may have relocated its armament storage to this stern area in order to make arms totally unavailable to the slaves on board. The appearance of small vessels in the foreground suggests that the ship is being outfitted for the trade, these are structural features. The hatches near the water line have covers and are small in size. These hatches or suckers are there for air flow but also provided security and can be closed if need be. "The Rear of the Slave Ship Aurora" is one of the best illustartions of a slave ship (Figure 6.2).

The French ship, L'Aurora, is documented through an artist's rendering produced by Jean Boudriot and published in 1984. A marine archeologist and historian, he was trained as an architect and has been able to bring a high degree of realism and accuracy to his depictions of ships. What is remarakbale about the second in the series of images he created (Figure 6.2) is that its full cutaway shows not only the deck in which slaves would have been stored but also the lower hold where provisions would have been kept. L'aurora only completed one journey as slaver before she was brought into the French and English naval conflict. This image clarely illustartes the presence of bulk heads, and while it falls prey to some of the same spacial issues as the Brooks, the plausablity of this many captives on the vessel is more acuarate.

The image "The Fredensborg II heading for St. Croix with a cargo of slaves" painted in 1788 pictures the Dutch Slaving vessel Fredensborg II (Figure 6.4). ${ }^{270}$ Thought to be particularly accurate, as the predecessor to this ship sank very near

${ }^{270}$ Leif Svalesen, The Slave Ship Fredensborg (Kingston: Ian Randle Publishers, 2000). 
shore, this ship was built for the same purpose and design. ${ }^{271}$ National sympathy and interest in the ship was also peaked as it sank so close to the shore. The image shows the ship in port view in the foreground, starboard view in the background, as well as from stern. This image depicts many of the features unique to a slaving vessel. These features include airports, air funnels, netting, a gun deck, a barricade at both the forecastle and the stern castle, evidence of a slave stove, smaller boats for loading and unloading, and an excessive number of sails (both square and lateen).

Unique to this image is the appearance of their air funnels or wind sails. These funnels are white canvas and are set up to draft wind down into the lower holds where slaves were located in an attempt to circulate air below decks better and reduce mortality rates. Pictured here are three such sails. The two forward sails would funnel air down into the male holding area while the third would funnel air down to the

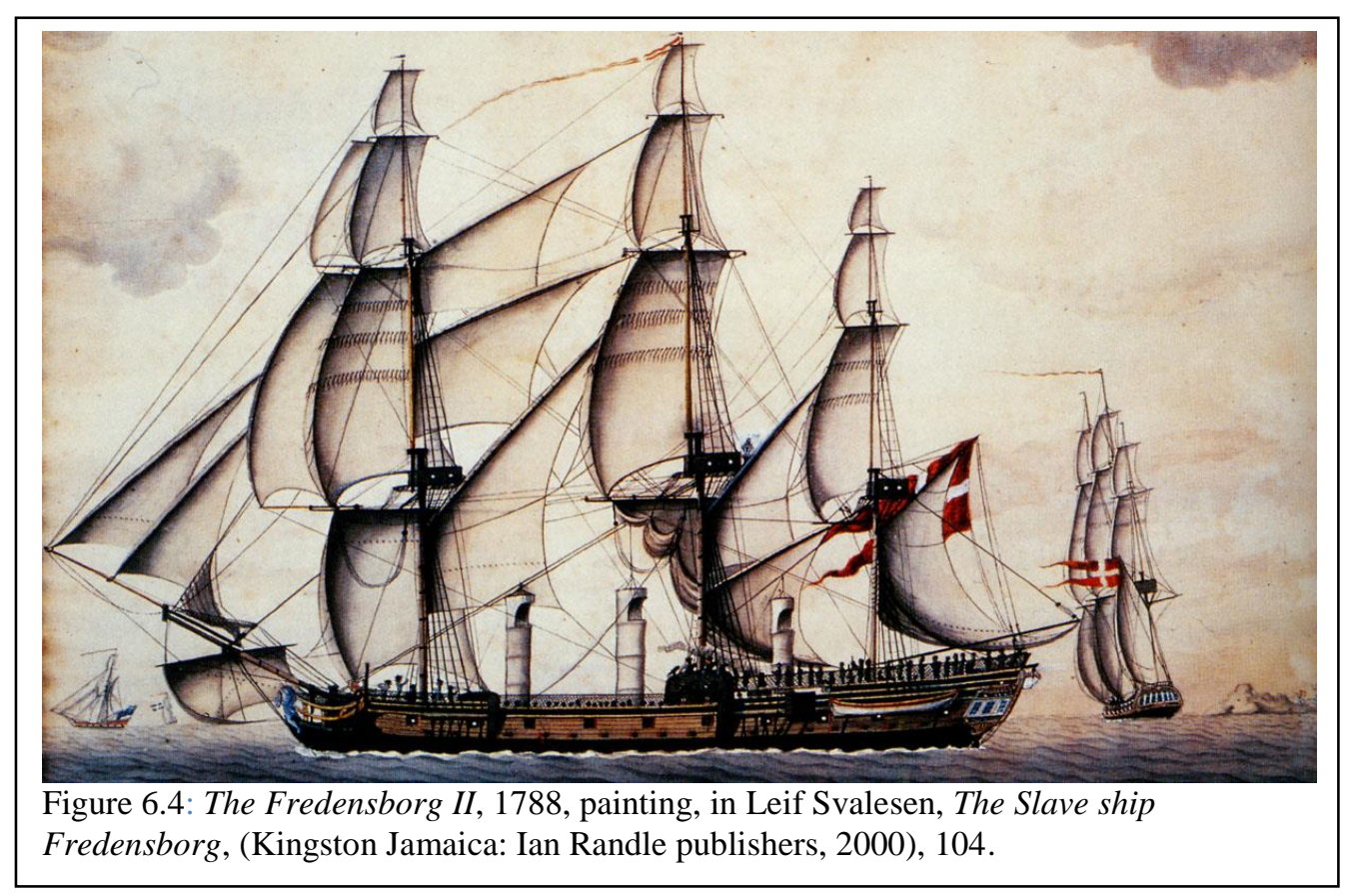

\footnotetext{
${ }^{271}$ Ibid., 104.
} 
female holding area. ${ }^{272}$ The second deck airports are visible; another measure to help air circulation, these airports had hatches, suggesting that when the wind sails are up it was possible to increase security by closing those hatches. Just below the gun deck it is easy to see the dozen black holes that depict the air holes.

Looking closely at the upper deck, the presence of netting is clearly visible. This netting was to prevent anyone jumping overboard. An additional visible security features is the barricade; the Fredensborg II has not one but two barricades. These barricades separate the forecastle and a stern castle, from the waist of the ship which is lower. The presence of slaves in this middle area required the use of these barricades both for safety in the event of an uprising and also to help separate crew from cargo.

Unlike many of the English and American vessels, this ship does have a decorative style. This is seen in the figurehead in the bow as well as the alternating colored railing of the deck of the ship between black and yellow. In this image, unlike others, the appearance of smoke from just behind the stern barricade indicates the presence of a slave stove just between the main and mizzen mast. Food could be passed through the barricade to the slaves in the middle of the ship. This also suggests that the galley is under the stern castle, another security feature.

\footnotetext{
${ }^{272}$ Ibid., 106.
} 
This image also shows the presence of two boats to go ashore, and neither is stored in a manner that is accessible to the captive cargo. Instead they dangle over the side of the deck on each side of the stern castle, as opposed to being stacked on deck as was common on other merchant vessels. Finally, the excessive number of sails illustrates a trend among slavers. The more sails, the faster a ship might sail, bit it compromises the ability to maneuver the vessel quickly.

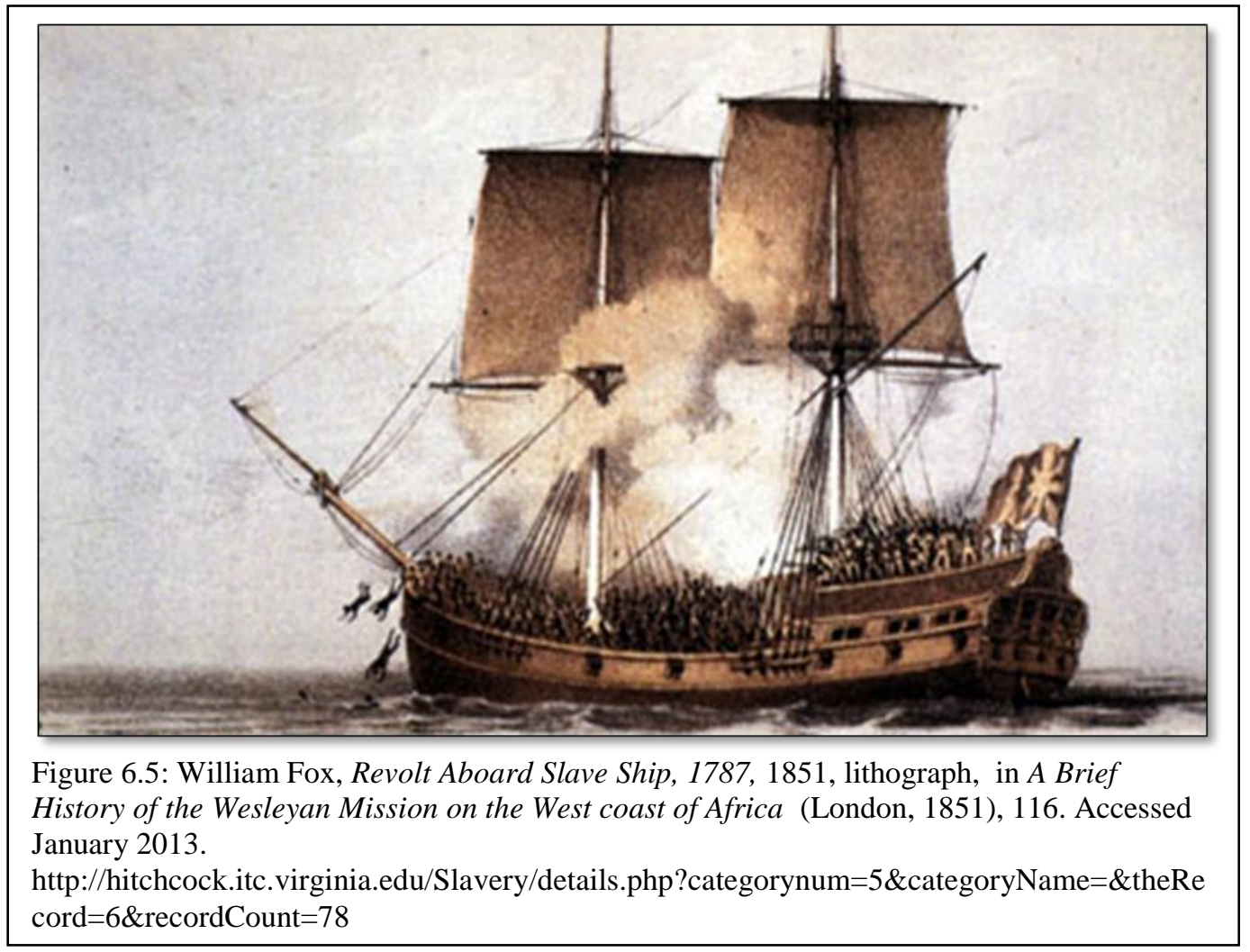

In this image of a slave insurrection (Figure 6.5), some of the defensive features of a slave ship can be seen. First is the barricade. This was a 10 to 12 foot wall that divided the ship so that the crew could have a defensible position from the slaves if they were able to rise. It typically separated the already elevated castle from the rest of the ship. This allowed for the crew to have higher ground and to be able to shoot through the slates down at the slaves. This ship also lacks decoration which 
points to it being a slaving vessel, but the lack of visible airports on the lower deck

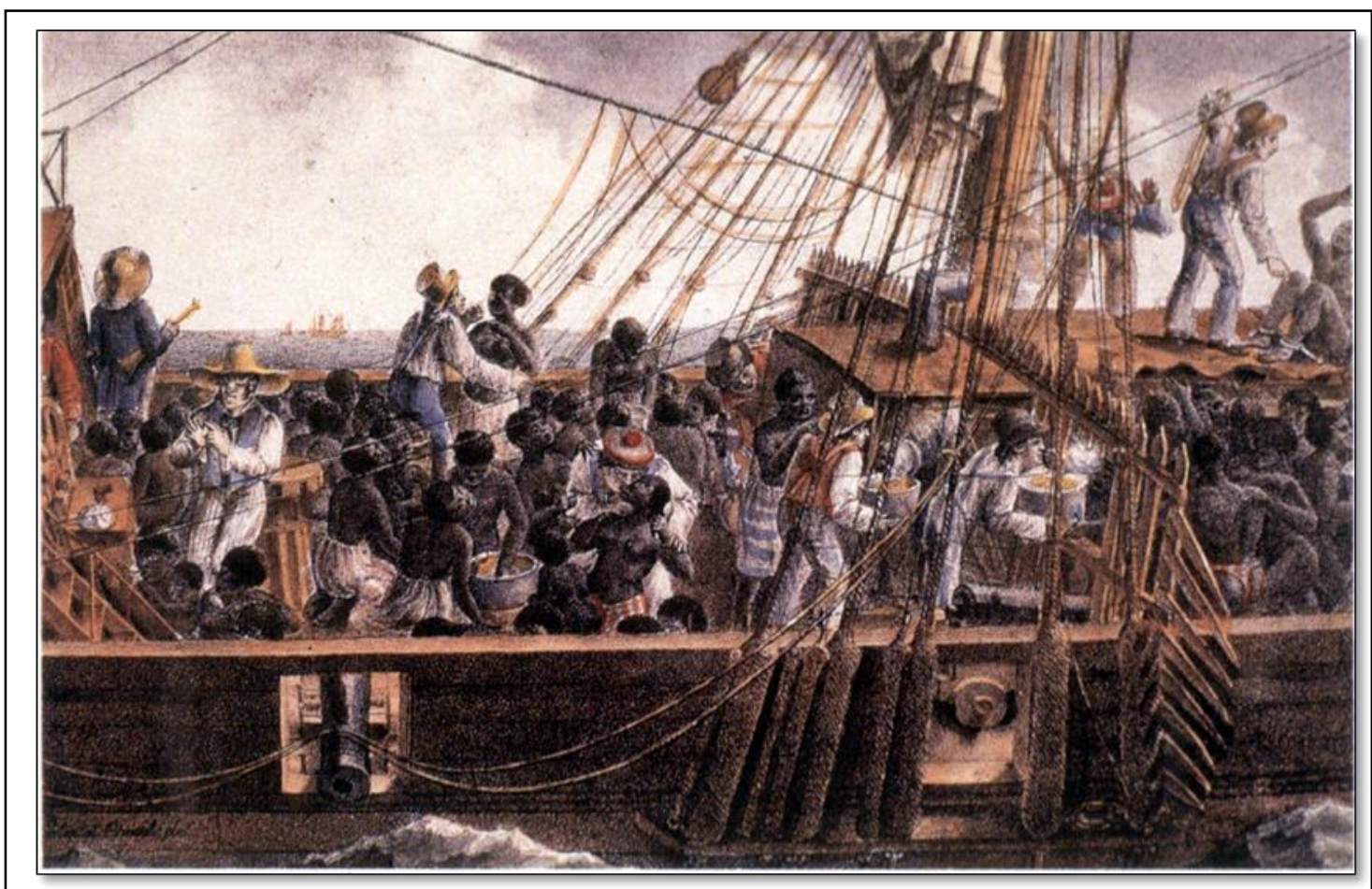

Figure 6.6: Pretexat Oursel. Transport des Negres dan les Colonies," Color lithograph, in Anneaux de la Memoire: Nates-Europe-Afriques-Ameriques, Chateau des Ducs de Bretagne, (Nantes, France 1992). http://hitchcock.itc.virginia.edu/SlaveTrade/collection/large/E009.JPG

could mean either that the artist chose not to include them did not know about them, or that this ship was converted to a slaver and therefore did not have airports. It, that the artist did not know to include airports as this image is from a newspaper story that discusses a recent slave insurrection and the artist was not there to witness the event. $^{273}$

This image shows an up-close look at a barricade with the woman and children on one side and the men on the other. There is a slave stove in this image as well, but it is not visible except the chimney and the sailors removing the large communal pots that would be used by the slaves. Rather than give the slaves their own bowl, each was

\footnotetext{
${ }^{273}$ Pretexat Oursel, Transport des Negres dan les Colonies, " Color lithograph, in Anneaux de la Memoire: Nates-Europe-Afriques-Ameriques, Chateau des Ducs de Bretagne, (Nantes, France 1992). http://hitchcock.itc.virginia.edu/SlaveTrade/collection/large/E009.JPG.
} 
given a spoon and eat from a communal pot. ${ }^{274}$ This image is a slight caricature of a vessel, but shows the temporary nature of a barricade and makes it easy it imagine how a structure like this could be constructed and deconstructed as needed.

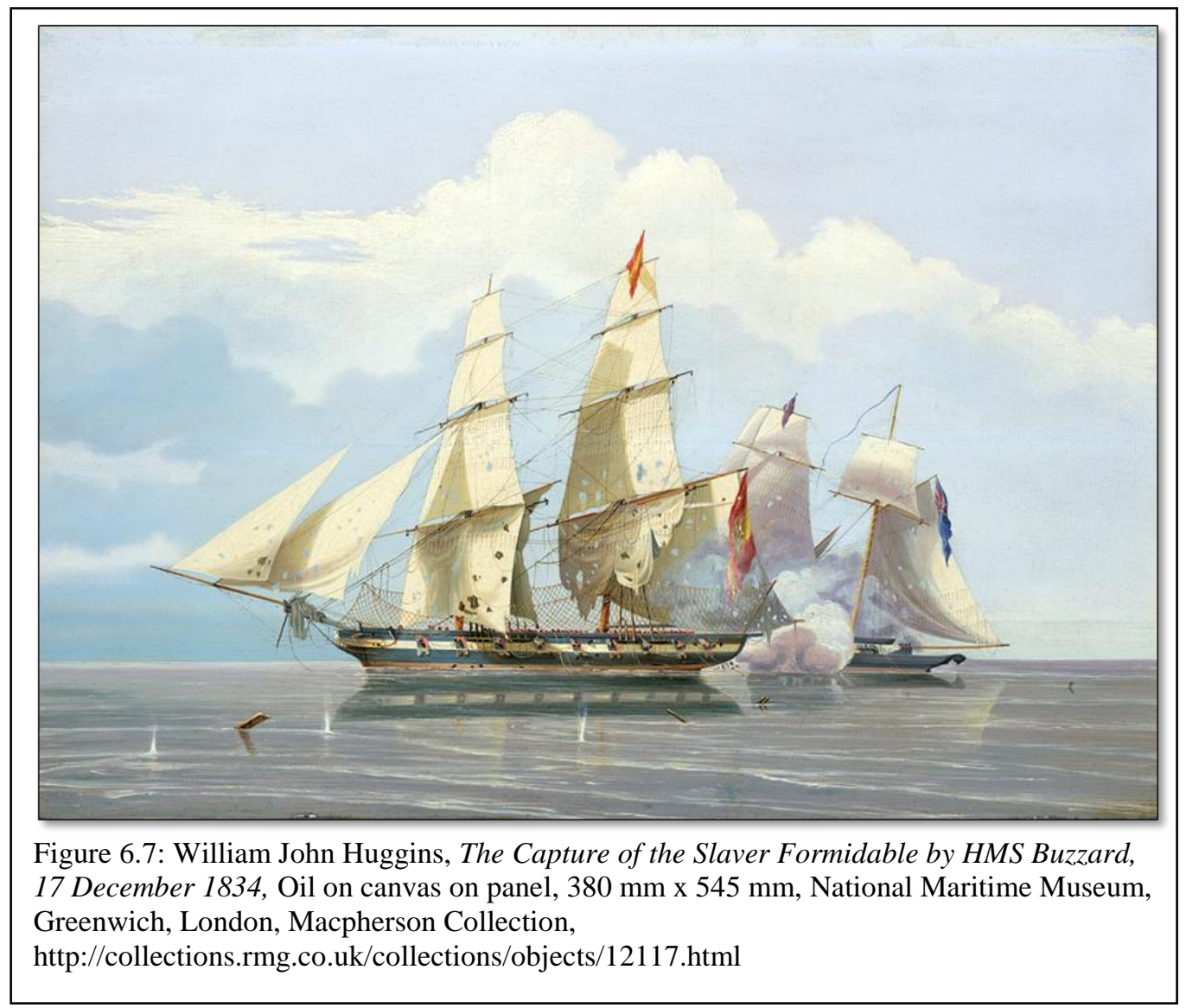

In Figure 6.7, another temporary security feature is visible, netting. ${ }^{275}$ This is an image of a Spanish ship and is one of many produced after Britains 1807 Act of abolishing the slave trade. This imagesembodies pride in the British Royal Navy for c apturing slaving vessels as popular option turned further away from slavery. ${ }^{276}$ This particular image features the capture of the slaving brig 'formidable,' which was taken

\footnotetext{
${ }^{274}$ Tom H Wells, The Slave Ship Wanderer (Athens: University of Georgia Press, 2009), 13.

${ }^{275}$ William John Huggins, The Capture of the Slaver Formidable by HMS Buzzard, 17 December 1834, Oil on canvas on panel, $380 \mathrm{~mm}$ x $545 \mathrm{~mm}$, National Maritime Museum, Greenwich, London, Macpherson Collection, http://collections.rmg.co.uk/collections/objects/12117.html.

276 Act of Prohibit the Importation of Slaves, 1807. Section 2- 10, United States Constitution and Acts. http://abolition.nypl.org/essays/us_constitution/5/, Accessed Feb. 12, 2013.
} 
by HM brigantine 'Buzzard' on the $17^{\text {th }}$ of December $1834 .{ }^{277}$ The ship was captured in 45 minutes with very few casualties, and taken to Freetown, Sierra Leone. Of particular significance is the netting on the vessel. This netting was used to prevent slaves from jumping overboard in attempted escape/suicide. In this case and in the case of other vessels participating in the slave trade after it became illegal it may also have been up in an attempt to keep other parties from boarding during an attack.

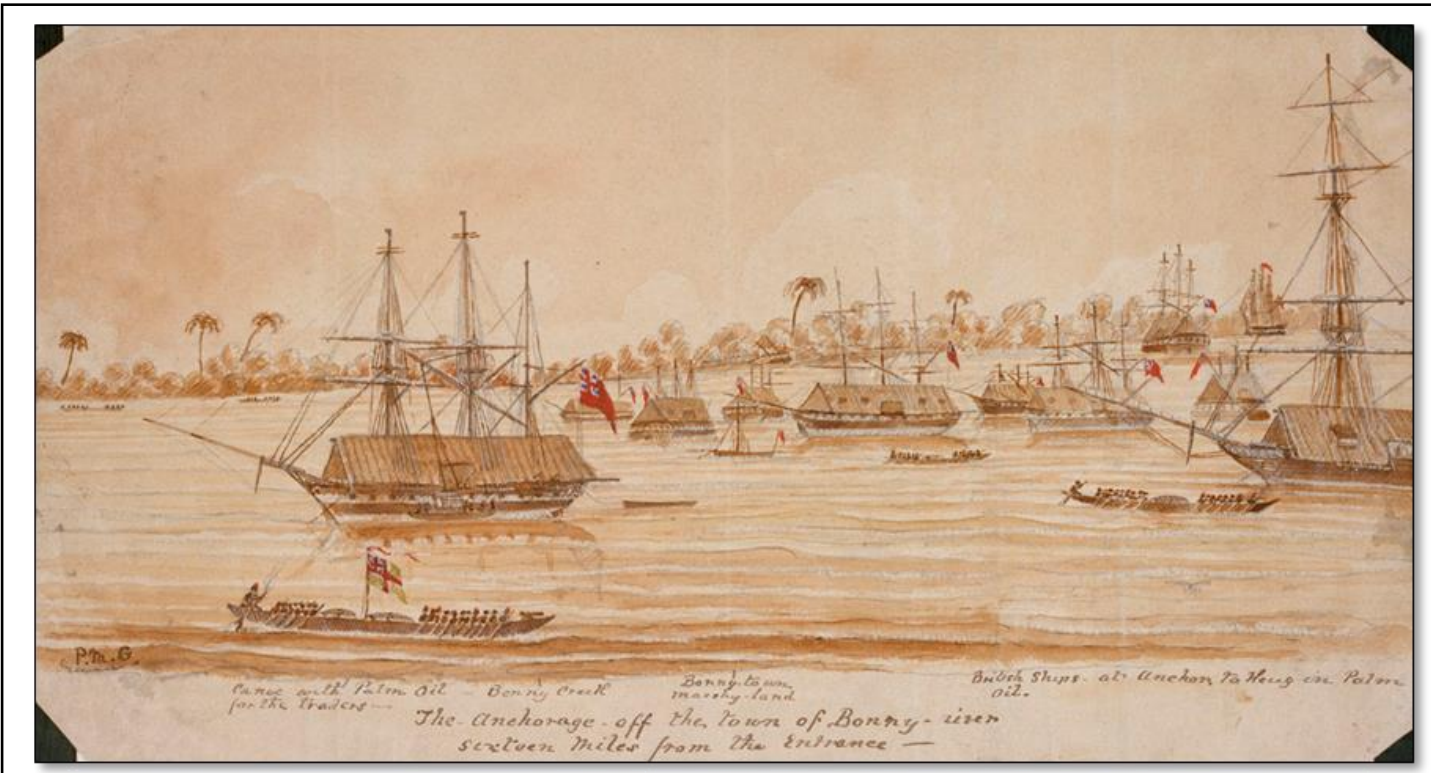

Figure 6.8: The anchorage off the Town of Bonny River sixteen miles from the Entrance, water color with graphite, 200mm x 370mm, national Maritime Museum, Greenwich London, http://collections.rmg.co.uk/collections/objects/106080.html

Regardless, this is a feature that is unique to slaving vessels, as its purpose is to prevent escape. ${ }^{278}$ What may be un-characteristic of the actual vessel is its height out of the water. Ships during this period usually had lower free board.

${ }^{277}$ William John Huggins, The Capture of the Slaver Formidable by HMS Buzzard, 17 December 1834, Oil on canvas on panel, $380 \mathrm{~mm}$ x $545 \mathrm{~mm}$, National Maritime Museum, Greenwich, London, Macpherson Collection, http://collections.rmg.co.uk/collections/objects/12117.html

${ }^{278}$ The anchorage off the Town of Bonny river sixteen miles from the Entrance, water color with graphite, 200mm x 370mm, national Maritime Museum, Greenwich London, http://collections.rmg.co.uk/collections/objects/106080.html 
In an image of a ship off the coast of Sengal (Figure 6.9) this is the case.

Produced to show

the castle on the

coast and the

large city there, a

ship is in the

forefront. The

ship is rather

non-descript but

when examined

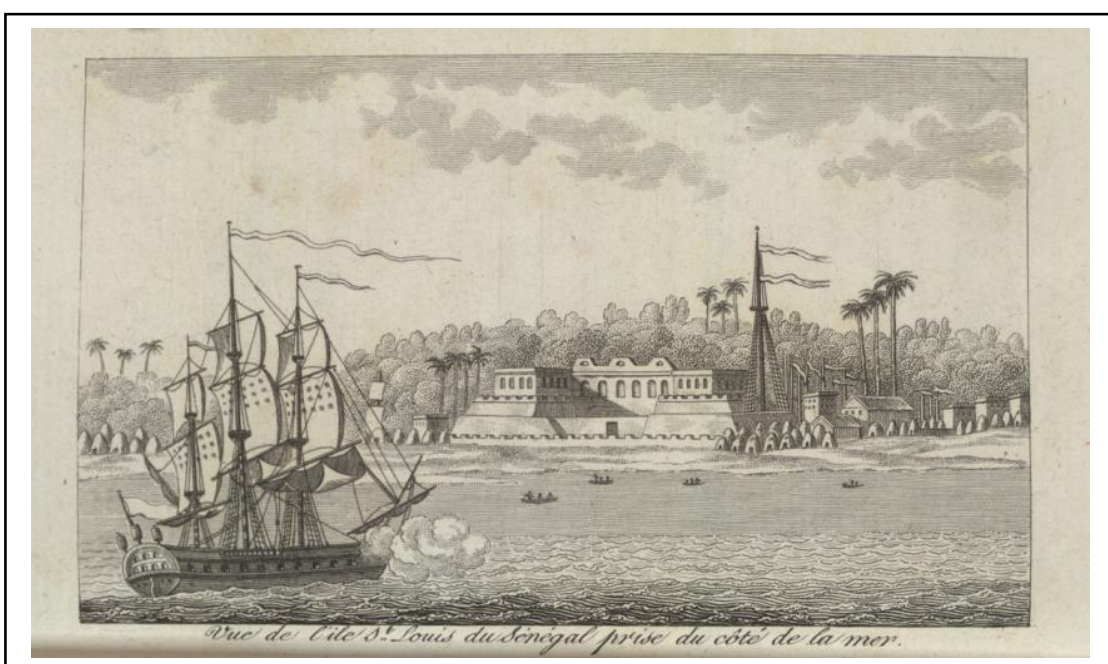

Figure 6.9: Ile St. Louis near the mouth of the Senegal River, 1814 "Vue de l'île St. Louis du Sénégal prise de côte de la mer." René Claude Geoffroy de Villeneuve, Illustrations de L'Afrique ou histoire, moeurs, usages et coutumes des Africains. Nepveu. Paris, 1814. Bibliothèque Nationale de France (ark:/12148/cb38495427c)

closely, low port holes are visible in the stern of the vessel. The plume of smoke near the bow, suggest that she is armed and the row of tiny boats making their way out to greet the ship suggest she is a merchant vessel. This with the addition of the known location of Saint-Louise or Ndar in Wolof, which is near the present day capital of Sengal, a known slave port, confirms that this vessel is a slaver. The lack of other disguisable features accounts for the year this image was created, 1814. Despite being a French vessel, where the slave trade was still illegal, in the eyes of the British Royal Navy this ship was operating illegally. Being targeted by the British Royal Navy this vessel likely removed many of the features that would have made her an easy target for. She too has a low free board and only a single visible deck.

Nets may have kept slaves alive at sea but ships would place awnings on their ships for the long stays that they would encounter while anchored off the coast to keep captives and crew alive in the sweltering heat. When ordering the construction of a 
ship in 1772, Aaron Lopez requested: a double deck brigantine- with awning, grating, and airports. ${ }^{279}$ The awning suggests that the vessels would be anchored for long periods on the African coast. ${ }^{280}$

Awnings exist in two varieties, simple awnings that cover the gratings and the hatches to prevent sun from going below decks. These types of awnings are seen in (Figure 6.11). The second type of awning is like that seen in the image "The Anchorage off the Town of Bonny River sixteen miles from the Entrance" (Figure 6.8) in which the awning covers the entire deck of the ship.

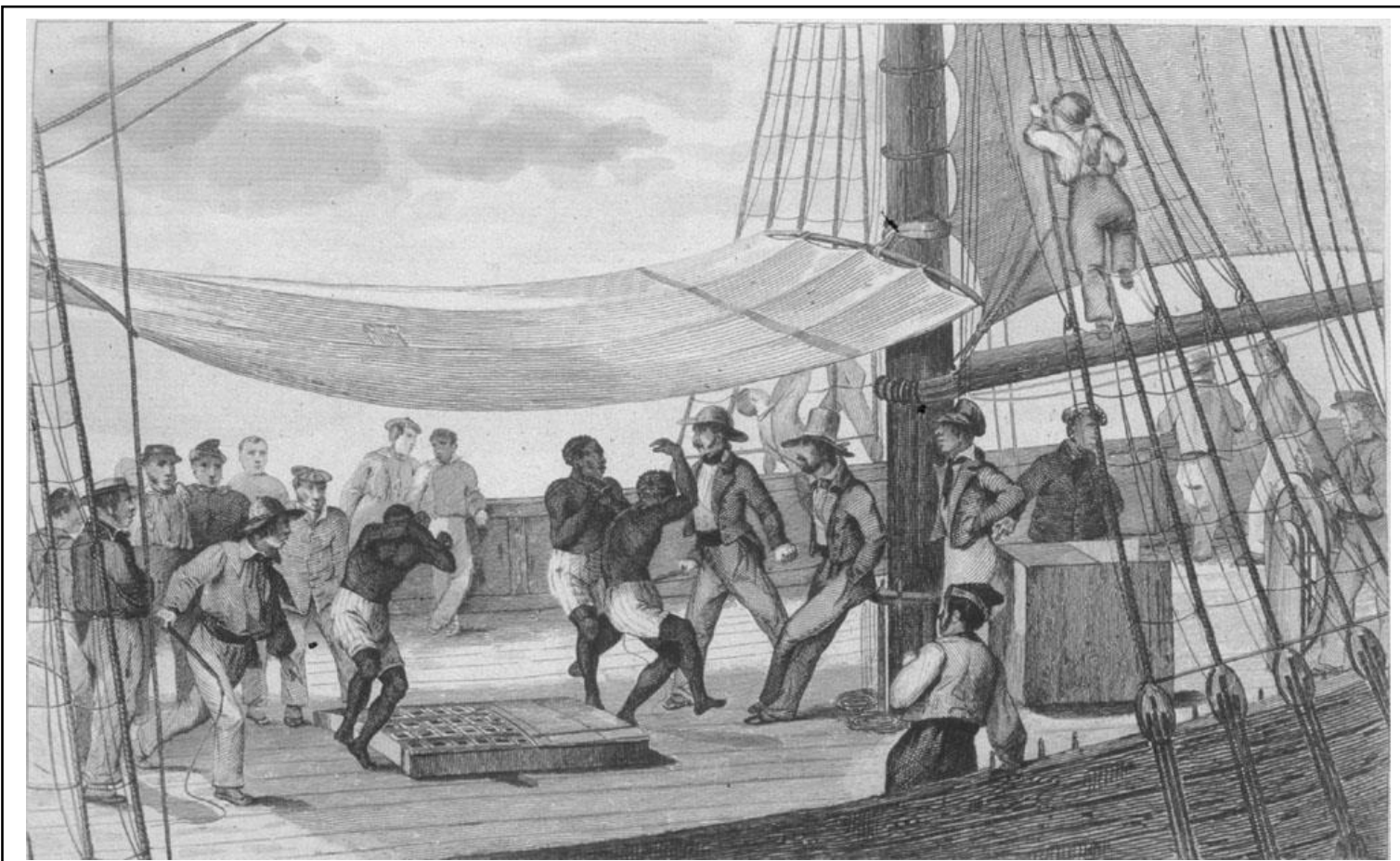

Figure 6.11: Dansa de Negres, 1837, Illustration, in Amedee Grehan, La France maritime, 3(1837), 179. http://hitchcock.itc.virginia.edu/Slavery/details.php?categorynum $=5 \&$ categoryName $=\&$ theRecord $=12 \&$ recordCount $=78$

Intended to cool the vessel in the warm tropical and humid air of the coast of

Africa, this innovation was particularly important when vessels took months to load.

\footnotetext{
${ }^{279}$ Howard Chapelle, The Search for Speed under Sail 1700-1855 (New York: W.W. Norton \& Company, 1967), 300..

${ }^{280}$ Junius P. Rodriguez, "Shipbuilding," The Historical Encyclopedia of World Slavery Volume 1-7 (Santa Barbara: ABC-CLIO, 1997).
} 
Prolonging the loading of the ship lowered the mortality rate of the captives who boarded the ship in the first few days or weeks of a sometimes 6 month wait. This also increased the mortality of the crew.

Figure 6.8 is an image pulled from the journal of crew member. It is charcoal and water color and shows several ships under awnings all English colors and transports of cargo going to and from the vessels. The vessel in the fore front is even lowering a boat to be sent ashore. All the vessels are of different type and have minimal decoration. Also of note is the semi-permeant nature of some of the awnings, these are characterized by the presence of ventilation hatches. Shade and air flow were both thought to be important in the attempt to survive on the African coast.

The second type of awning, as seen in Figure 6.11, covers the grating over the hatch leading below deck. It is also a more appropriate awning to be in place for a ship under sail. Cargo mortality was important and with limited water supplies, shade could be a life prolonging measure. This image does showcase many of the other features that would be expected on a slave ship, but as it is not dated, only that it comes from the early nineteenth century it could be this is a vessel engaging in illicit trading. 
This French vessel (Figure 6.12) shows many of the specialized features of a slave vessel. Thought to be an image of the ship of the coast of Africa, many of the

features that are
added before
arrival are visible.
This ship has the
presence of a
metal barricade
before the main
mast. The
placement of this
barrier and its
more permanence
relative to a
woodened barrier
suggest that the
ship is

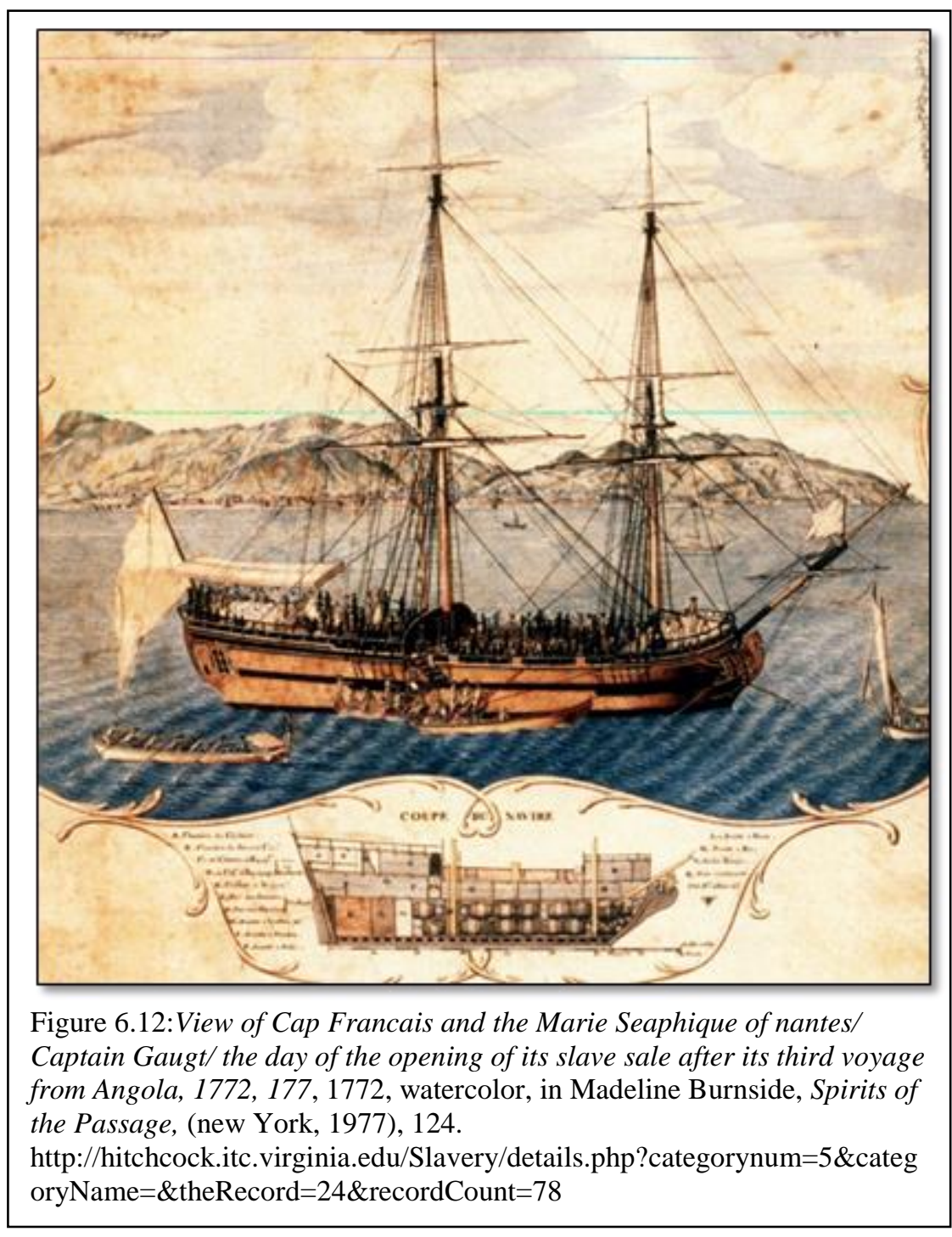

reconfigured in a manner that would make the galley more accessible and the weapons store less.

The awning on the stern of the vessel is there both for cooling of the vessel but also for what appears to be the casual nature of buying slaves on board. There is a raised area both in the forward part of the ship and the rear. This image is credited to 1773, but the cut way below the main image may have been added later. It too, shows 
the placement of the bulk heads as well as the deck spacing for the separation of living cargo and provisions. What is missing from this image are any lower hatches and any guns, which a French vessel in 1773 would have without question carried.

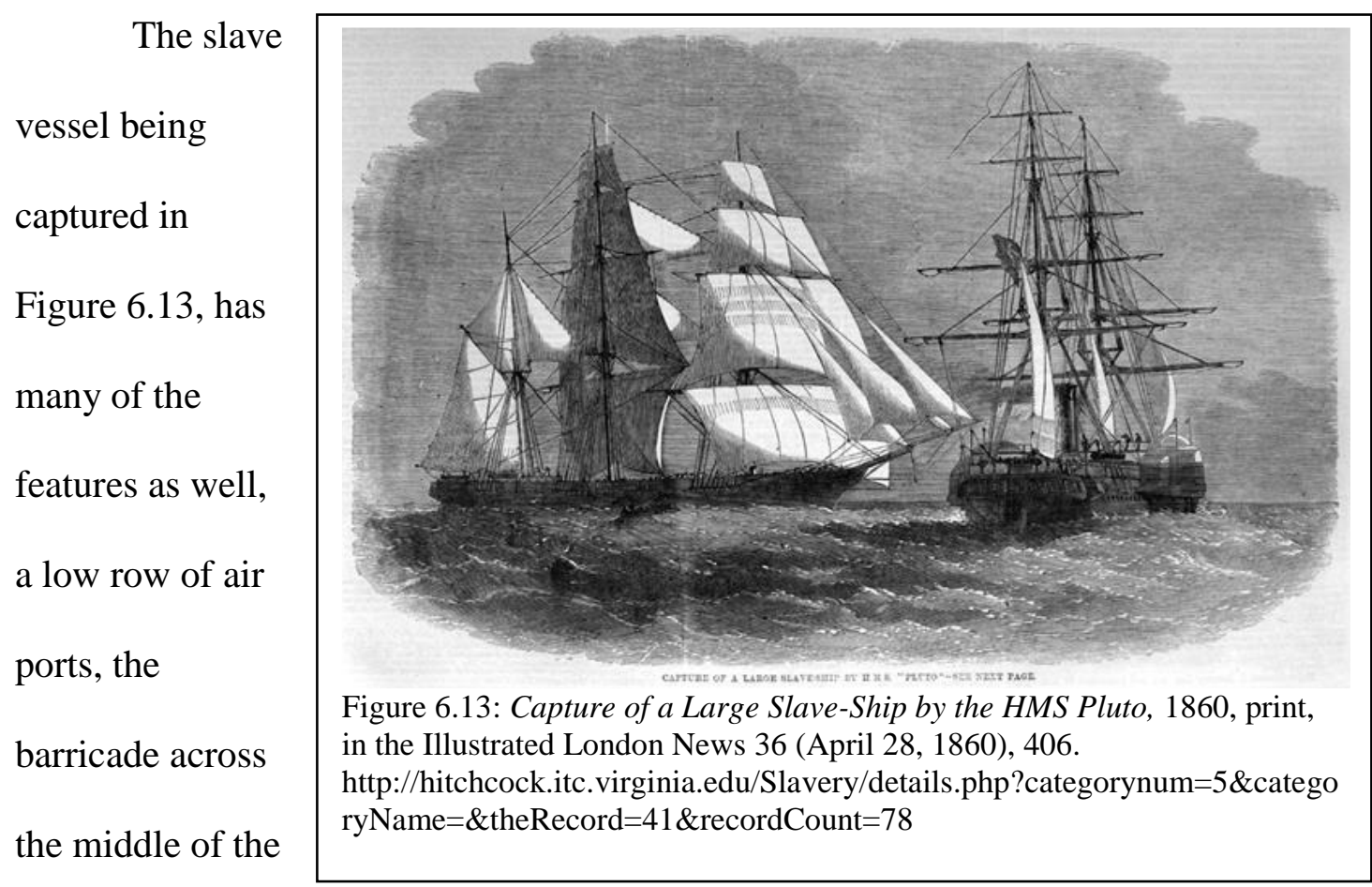

ship, air funnels on each side, and an elevated bridge. In this image of the

Frondensburg 2, which is thought to be a replica of her predecessor, many of the traits that would be useful in a slave ship are represented. ${ }^{281}$

This image from the Illustrated Times (Figure 6.13) while somewhat accurate was produced in accordance with abolitionist ideas and to promote the work of the British Navy. The British Royal navy and its special squadron of ships going after traffickers produced or inspired a large number of images like this one.

${ }^{281}$ The Fredensborg II, 1788, painting, in Leif Svalesen, The Slave Ship Fredensborg (Kingston Jamaica: Ian Randle publishers, 2000), 104. 
Images of life below decks also inspired people to support the anti-slave trade

movements. Images of the navy

capturing a vessel would often be

accompanied by an artist's idea what

they may have found below decks.

There is some debate as to

whether or not the height and space

between decks is a special feature of

slave ships. Many historians are inclined

to view the 4 to 5 foot space between

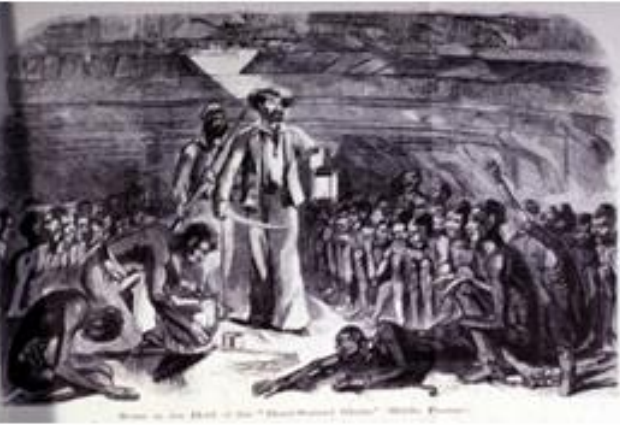

Figure 6.14: Richard Drake, Scene in the Hold of the 'Blood-Stained Gloria' (middle passage), 1860, Print, in Revelations of a Slave Smuggler (New York, 1860), 28.

http://hitchcock.itc.virginia.edu/Slavery/details. php?categorynum $=5 \&$ categoryName $=\&$ the Rec ord $=13 \&$ recordCount $=78$

decks as special as is it is higher than many spaces on ships of the seventeenth and eighteenth centuries, however it was common on passenger ships. In this study, these ships are classified as cargo ships, which mean that indeed the extra space represents a special feature.

The fact that the ship was double-decked meant that below the slave deck was a lower hold that could carry both provisions for the slaves and some extra

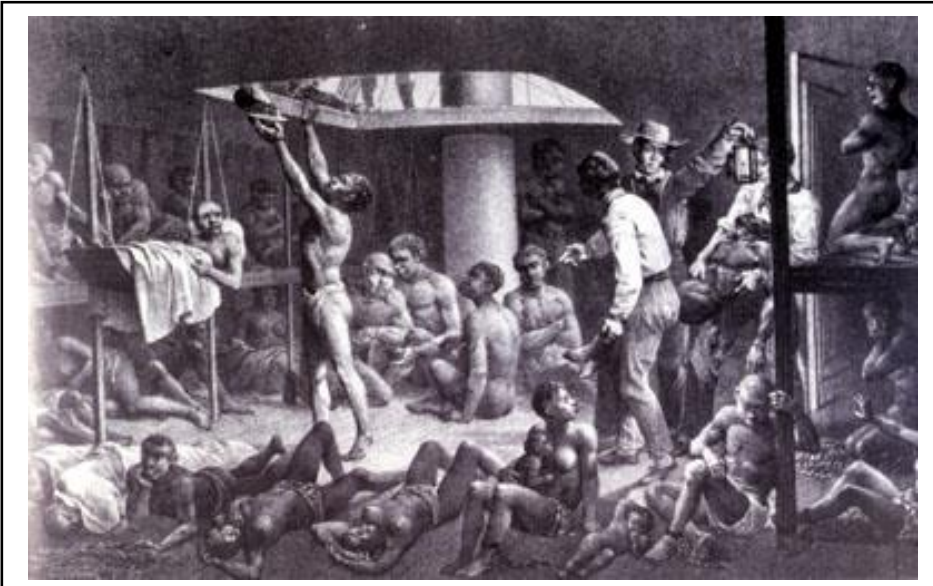

Figure 6.15: Negres a fond de calle, 1835, Lithograph, in Robert W. Slenes, African Abrahmas, Lucretias and Men of Sorrows, Allegory and Allusion in the Braziliam Anti-slavery Lithographs (1827-1835) of Johann Moritz Rugendas, (Slavery \& Abolition, vol. 23, 2002), 147168.

http://hitchcock.itc.virginia.edu/Slavery/details.php?categorynum=5\& categoryName $=\&$ theRecord $=15 \&$ recordCount $=78$ 
cargo. ${ }^{282}$ In Figure 6.14 from the book Revelations of a Slave Smuggler by by Richard

Drake in 1860 , there is an image

captioned "Scene in the Hold of the

'Blood-Stained Gloria'(Figure 6.14)

which pictures dozens of slaves in the

hold of a ship being examined by

members of the crew. There is a lot

more room than would be expected, or

that would have existed in reality. This

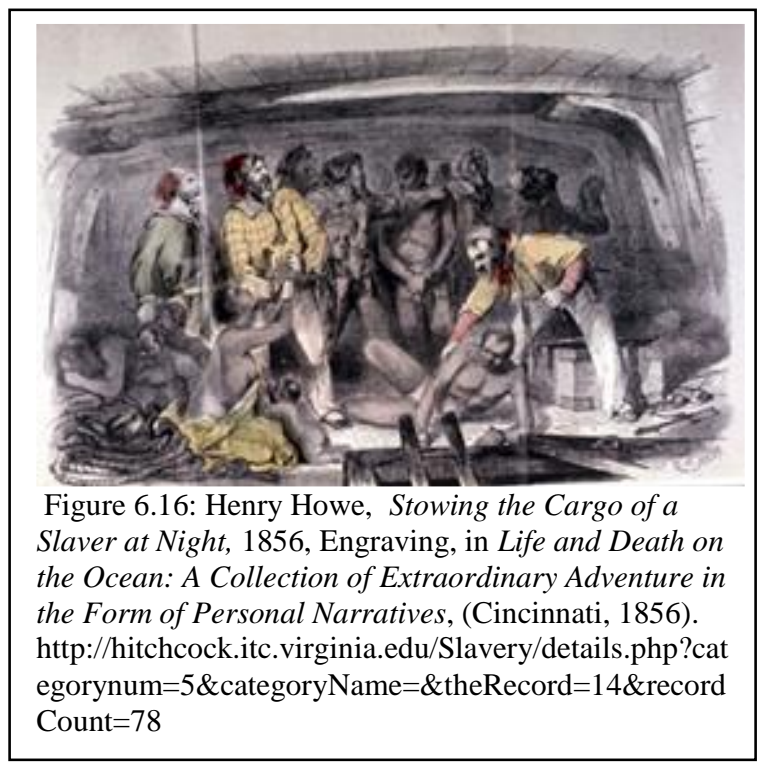

image does illustrate the ship'shold during the latter period of the slave trade when it

had become illegal. While the racks that are common on larger ships are missing, the raw wood and the hanging knees are clearly visible. Drake spent approximately two years on the slave ship and participated in several voyages. Although his vernacular takes an abolitionist tone, and some of his book is highly contested, this image illustrates conditions below deck. ${ }^{283}$ It could be argued that there is more than the customary head space of $41 / 2$ to 5 feet, as there is space for the crew member to walk around and have significant headspace which would have been unlikely.

The same could be said for image from Henry Howes Life and Death on the Ocean: A Collection of Extraordinary Adventures in the Form of Personal

\footnotetext{
${ }^{282}$ Junius P. Rodriguez, The Historical Encyclopedia of World Slavery Volume 1-7 (Santa Barbara: ABC-CLIO, 1997).

${ }^{283}$ Richard Drake, Scene in the Hold of the 'Blood-Stained Gloria' (middle passage), 1860, Print, in Revelations of a Slave Smuggler (New York, 1860), 28.

http://hitchcock.itc.virginia.edu/Slavery/details.php?categorynum $=5 \&$ categoryName $=\&$ theRecord $=13 \&$ recordCount $=78$
} 
Narratives. ${ }^{284}$ Illustrating the "stowing the cargo of a slaver at night". This engraving from 1855, from an excerpt from Captain Canot's Narrative, shows what is supposed to be below decks of a slaver during the illegal period. This image seems to be very unrealistic, there is plenty of room overhead, men and woman are mixed together, and all have access to shipboard goods. The image was created by the author of the collection

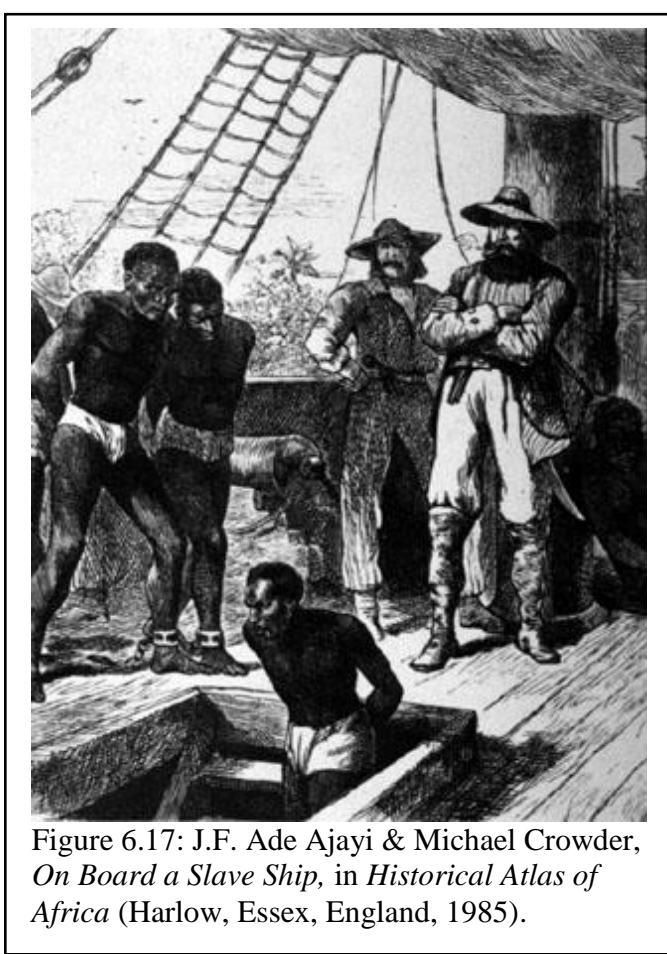
and not from personal accounts but it demonstrates the popular conceptions held about slave ships, in this case, making below deck life looking better than it was.

Abolitionists continually influenced the images produced regarding the slave trade, especially art produced after 1807. Johann Moritz Rugendas of France produced several images with abolition in mind, especially with regards to the trade in Brazil. In this particular image captioned "negres a fond de calle" shows men woman and children below decks. Again the space between decks is much too large, there is more headroom than would exist in reality. The men and woman on board would have been separated. This image does nicely illustrate the racks that were installed below decks and the placement of the mast through the deck of the ship. ${ }^{285}$

\footnotetext{
${ }^{284}$ Henry Howe, Stowing the Cargo of a Slaver at Night, 1856, Engraving, in Life and Death on the Ocean: A Collection of Extraordinary Adventure in the Form of Personal Narratives, (Cincinnati, 1856).

http://hitchcock.itc. virginia.edu/Slavery/details.php?categorynum=5\&categoryName=\&theRecord=14\& recordCount $=78$

${ }^{285}$ Negres a fond de calle, 1835, Lithograph, in Robert W. Slenes, African Abrahmas, Lucretias and Men of Sorrows, Allegory and Allusion in the Braziliam Anti-slavery Lithographs (1827-1835) of
} 
The above images (Figure 6.17, 6.16, 6.15) all have open hatch access to the space below decks. A more accurate depiction of this access is shown in an image from J.F. Ade Ajayi and Micheal Crowders Historical Atlas of Africa. ${ }^{286}$

It is suspected that the image is not based on a first person account, but unlike previous images discussed here this image shows a staircase going down into the hold. This is constant with descriptions from other slavers.

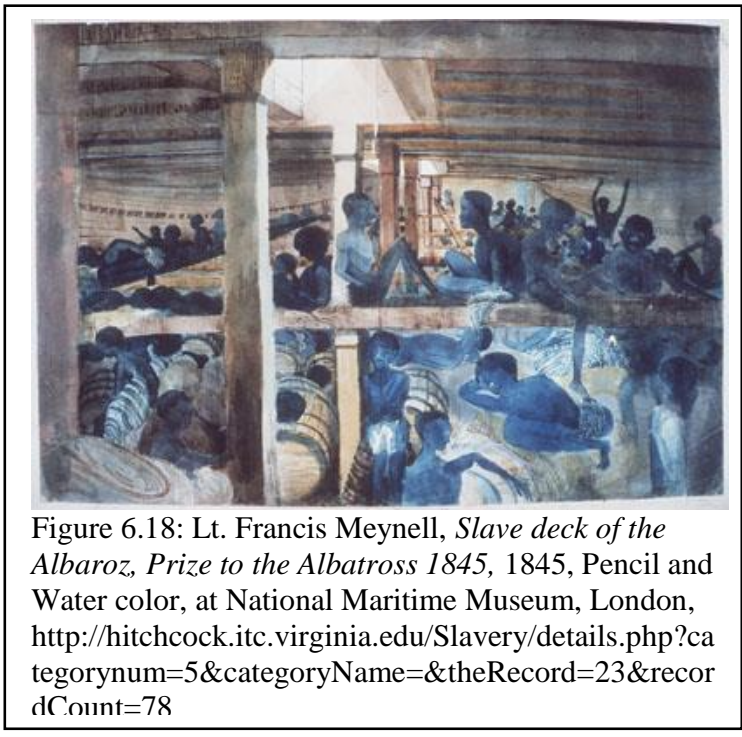

This ladder would lead to a narrow hallway that ran between the racks placed in the lower decks. This ladder/ staircase was also a more convenient way to bring captives above deck to "exercise" them. ${ }^{287}$

All of the images depicting the below deck space are showcasing ships that were transporting slaves after the English and American Acts of 1807, they are heavily influenced by abolitionist ideals. Many of these images were generated by the experience of the British Royal Navy. In this penciled watercolor by Lt. Francis Meynell titled "Slave deck of the Albaroz, Prize to the Albatross, 1845"( Figure 6.18), the site that Meynell encountered upon the capture of the Brazilian vessel in $1845 .{ }^{288}$

\footnotetext{
Johann Moritz Rugendas, (Slavery \& Abolition, vol. 23, 2002), 147-168.

http://hitchcock.itc. virginia.edu/Slavery/details.php?categorynum=5\&categoryName=\&theRecord=15\& recordCount $=78$ Figure

${ }^{286}$ J.F. Ade Ajayi \& Michael Crowder, On Board a Slave Ship, in Historical Atlas of Africa (Harlow, Essex, England, 1985).

${ }^{287}$ James Rawley and Stephen D. Benrendt. The Transatlantic Slave Trade: A History. (University of Nebraska Press 2005), 244.

${ }^{288}$ Lt. Francis Meynell, Slave deck of the Albaroz, Prize to the Albatross 1845, 1845, Pencil and Water color, at National Maritime Museum, London,
} 
This vessel was a sleeker vessel with less deck space, the inter-mingling of captives and water barrels shows the nature of the illegal trade. There is still the presence of racks; however, this ship is more crowded than this image shows.

The features of these ships made it possible to transport human cargo across the Atlantic and beyond. These features also made it possible for ships to spend long spans of time on the coast of Africa. By utilizing the images that where created contemporarily with the slave trade, features unique to the slave trade can be seen in use. Features that owners and builders felt where not worth description or where selfevident capture the attention on sailors and observers, making these images from paintings to journal entries some of the only records in existence pertaining specifically to these features. This is especially important as many of these features may not survive in the archaeological record or may have been constructed over if a ship was repurposed for military and other uses.

http://hitchcock.itc.virginia.edu/Slavery/details.php?categorynum=5\&categoryName=\&theRecord=23\& recordCount $=78$ 


\section{CHAPTER 7}

\section{CONCLUSION}

Change in slave ship structure and construction over time, based on the needs of the market and changing demand on merchants and crews, and has been documented in this study. These changes are reflected in the ship structure (i.e. size, angle of the stem post, arrangement of crew and cargo), modifications done to vessels during different legs of the journey (arrangement of freight, fortifications, number of guns, netting, walls, etc.), and finally the commissioned purpose of the ship (ships built to go to Africa vs. ships fitted or modified to go to Africa). This evidence proves conclusively that at least some ships where built specifically to particpate in the slave trade. The hypothesis that the ships used in the slave trade changed structurally in accordance with the ideas of both race and economics is suggested by this research, but cannot be proven conclusively.

Classifing slave ships as special purpose ships is still problematic. A "designdedicated" or "special purpose" ship is one that is built for a specific purpose, becoming more specialized over time such that it could not be easily used for any other purpose. ${ }^{289}$ Special purpose vessels include icebreakers, cable ships, and aircraft carriers. This term can also apply to other vessels that performed special functions before the modern military area. A special purpose ship is a ship that was built for one specific purpose and is so specialized in construction that it can either not be used for

${ }^{289}$ K.J. Rawson and E.C. Tupper, Basic Ship Theory Vol. 1 \& Vol. 2 (Longman Inc., New York, 1976): 310-320. 
any other purpose ( on a commercial level) or it must undergo specific modifications and alterations to be used for a purpose other than that for which it was built. A special purpose ship has specific characteristics that make it suitable for its purpose that would be superfluous to other uses or increase its commercial viability for one specific task.

Calling any slave ship a special purpose vessel is difficult. So many of these purpose built ships, even those specifically built for the slave trade, served other purposes after their lives as slaving vessels. Further, some of their specialized traits made them suitable for privateering or even naval service. As a result, slave ships were sometimes specifically sought out and commandeered by these parties. For it to be conclusively stated that purposely built slave vessels are special purpose vessels, the term special purpose vessel would need to be redefined. This redefinition would cause the reevaluation of many other vessels thought out naval history. While it may not be possible to classify a slave ship as a special purpose vessel, it can be said that slave ships were unique to the pre-industrial shipping industry. No other industry was fraught with as much controversy over such a long period of time, no other industry dealt with such unique needs for cargo and crew, and no other industry has had such mixed motives. All of these factors influenced the construction, fitting and modification of the ships themselves, making slave ships some of the most unique in maritime history.

All of these factors influenced the slave trade at large. The slave trade is a vast, and all-encompassing topic. Only when the evidence is examined from new angles can important patterns and trends appear, as can assertions about the nature of shipbuilding 
for the slave trade. Approaching the subject of study within a global rather than sitespecific or regional framework allows for conceptualizing wide-ranging processes and patterns that affected people and trends on even the smallest scale. ${ }^{290}$ While it would be impossible to compare every ship, looking at a cross section of the slave ships that are known can assist in examining slave ships discovered in the future.

Many potential future sites and ships are waiting for discovery. A survey of historic newspapers and insurance from (insert period) found 261 wrecks of slavers; 85 British wrecks, 33 Irish wrecks, 97 West African wrecks, 72 Caribbean wrecks, 17 North American wrecks, 6 South American wrecks, and some 31 mid-Atlantic wrecks. ${ }^{291}$ If even a small portion of these where discovered and researched by archaeologists what is known about the structure and construction of slavers would grow exponentially. The material culture from these sites will also lead to a better understanding of the trade economy. Understanding trade routes is no longer enough, a deeper understanding of trade goods is needed. Many studies group the entire continent of Africa as a single market, making sweeping statements about the triangular trade. As is evident in the sheer diversity of goods traded, this is simply not the case. Africa has proven to be a rich and culturally diverse continent, as diverse, if not more, than Europe. The goods traded during the Seventeenth, Eighteenth, and Nineteenth century are just as diverse and regional. A better understanding of the diversity, both temporally and regionally of these goods, will assist archaeologists in the growing field of maritime research in and around ports that formally traded in

\footnotetext{
${ }^{290}$ Christopher DeCorse, The Archaeology of Elmina (Elliot Werner Publications 2001), 11.

${ }^{291}$ Michael Smith, "Locating Slave Shipwrecks: Innovative approaches to digital and archival resources," Presentation, Newcastle University, School of History, Classics and Archaeology.
} 
slaves.

In addition, further examination of the historical record and art related to the slave trade and the ships that participated in it will yield similar and as conclusive information. While ships in paintings are stylized, often illustrated are the exterior features unique to a slave ship. The number of paintings and their artistic quality is a testament to the place of the slave trade and the slave ship in the conscious memory of those alive during its height and subsequent abolishment. The same can be said for the number of documents related to the slave trade and slave shipping the world over. There are a staggering number of collections both in museums and archives and in the personal possession of the decedents of slave traders that upon further examination will greatly illuminate patterns and trends of ship builders, ship owners, and merchant traders.

Finally, what this study has shown is that merchants acted with purpose and motivation. The slave trade, specifically the ships, generated a large economy that was not concerned with the morality of the slave trade. The building at outfitting of slave vessels also highlights the motivation of merchants, the people they worked with and the schemes that they participated in to generate a profit show that to many the slave trade was a money making endeavor not concerned with the humans being transported. While underlying racism allowed slave traders to participate in the industry, the business documents barely mention race. In these documents and in this correspondence, every decision is a calculated business decision with profits in mind. More work remains to be done to answer the many additional questions that this study raises about slaving vessels. As underwater cultural resources continued to 
be discovered hopefully the potential knowledge that slave ships contain is kept in mind. If the base of knowledge can shift from what is discovered after treasure hunter and salvagers pillage a wreck, to what archaeologist can discover using scientific methods and knowledge-based research, our understanding of slave ships will dramatically increase. 


\section{BIBLIOGRAPHY}

Account cost of Brigantine Diana (re-named the Hannah), 1768, Box 177, The Newport Historical Society Library, Newport Historical Society, Newport, Rhode Island

Act of Prohibit the Importation of Slaves, 1807. Section 2- 10, United States Constitution and Acts. http://abolition.nypl.org/essays/us_constitution/5/, Accessed Feb. 12, 2013.

Ajayi, J.F. Ade \& Michael Crowder, On Board a Slave Ship, in Historical Atlas of Africa, Harlow, Essex, England, 1985.

Alfred, William. Stowage of the British Slave Ship 'Brookes' under the Regulated Slave Trade, Act of 1788. 1790, Lithograph, Broadside Collection, Rare Books and Special Collections Division, Library of Congress.

Allen, Beny at Montego Bay, Aug 7, 1775, Box 126 Folder 19, The Newport Historical Society Library, Newport Historical Society, Newport, Rhode Island.

Alpern, Stanely B. "What Africans Got for Their Slaves: A Master Lift of European Trade Goods.” History in Africa 22 (1995): 5-43.

American History Leaflets. Colonial and Constitutional, No. 19-January, 1895. Extracts from the Navigation Acts, 1645-1696. A. Lovell \& Company, Great Britain 1895. Accessed Feb. 12, 2013.

Astley, Thomas. "Enslaved Africans being carried to a slave ship, Gold Coast, Late $17^{\text {th }}$ Century. " In A New General Collection of Voyages and Travels (London, 1745-47), vol. 2, plate 61 1745-1747. In University of Virginia Library 
Special Collections

http://hitchcock.itc.virginia.edu/SlaveTrade/collection/large/2-589a. JPG

Aston, T. S. An Economic History of England: the Eighteenth Century. Routledeg; Oxen, 2006.

Aguet, Isabelle. "Revolt aboard Slave Ship,". In A Pictorial History of the Slave Trade, by Isabelle Aguet, Plate 64; 71. Geneva, Editions Minerva, 1971. http://hitchcock.itc. virginia.edu/SlaveTrade/collection/large/E006. JPG

Balai, Leo. Slave Ship Leusden: A story of Mutiny, Shipwreck, and Murder. Norwick, UK:UTS publishing, 2014. Kindle Edition.

Behrendt, Stephen D. "Seasonality in the Trans-Atlantic Slave trade." Voyages: The Trans-Atlantic Slave Trade Database. Accessed January 1, 2013. http://www.slavevoyages.org/tast/assessment/essays-seasonality-01.faces.

Berlin, Ira. Generations of Captivity; a History of African-American Slaves. Harvard Press, 2003.

The Belfast News-Letter, Tuesday, April $8^{\text {th }} 1834$, issue 10102.

Bevan, J. The Infernal Diver: The Lives of Jon and Charles Deane, their Invention of the Diving Helmet, and its First Applications to Salvage, Treasure Hunting, Civil and Military Uses. London: Submex, 1997.

Bigelow, Bruce M. "Aaron Lopez: Colonial Merchant of Newport”, New England Quarterly 4 (1931): 757-776.

Bos, Carole. "The Triangle Trade," Amazing Stories, accessed January 2, 2015, https://www.awesomestories.com/asset/view/THE-TRIANGLE$\underline{\text { TRADEAmazing-Grace }}$ 
Bourdroit, Jean. Leg and Wrist Shackles used on Slave Ship, 1784, Line Drawing, in Jean Boudriot, Traite et Navire Negrier l'Aurore, 1784, Paris, Published by author, 1984.

The Rear of the Slave Ship Aurora, Monograph, reproduced from Jean Boudriot, Monographie De L'Aurore- Navire negrier-1784, Nice, France: Ancre. http://www.histoiremaritimebretagnenord.fr/activit\%C3\%A9smaritimes/la-guerre-en-mer/ Aurore Monograph, monograph, reproduced from, reproduced from Jean Boudriot, Monographie De L'Aurore- Navire negrier-1784, Nice, France: Ancre.

Bowens to Lopez, May 1764, Agreement to Build a Brig, Box 52, Folder 4, Sheet 52-143, Arron Lopez Papers, the Newport Historical Society Library, Newport Historical Society, Newport, Rhode Island.

Braun, Georg Franz Hogenberg, and John Goss .The City Maps of Europe: $16^{\text {th }}$ Century Town Plans from Braun \& Hogenberg. Chicago: Rand McNally, 1992. Print.

Briggs, Nathaniel, instruction on selling slaves, May 6, 1768, Box 177, The Newport Historical Society Library, Newport Historical Society, Newport, Rhode Island.

Briggs, Nathaniel, out fitting of the Brig Hannah, May 12 1768, Box 177, the Newport Historical Society Library, Newport Historical Society, Newport, Rhode Island.

Burney, William. New Universal dictionary of the Marine, 1815. Annapolis MD; US 
Naval Institute Press, 2006.

Cardinal, A.W. "Aggrey Beads of the Gold Coast.” Journal of the Royal African Society 24(1925): 287-298.

Casey, Silas \& John Gleslen to Arron Lopez, agreement for building a ship, 26 August 1773, Box 52, Folder 4, Sheet 52-177, Arron Lopez Papers, the Newport Historical Society Library, Newport Historical Society, Newport, Rhode Island.

Chapelle, Howard. The Search for Speed Under Sail 1700-1855. New York; W.W. Norton \& Company, 1967.

Chapman, Frederik, Architectura Navalis Mercatoria: The Classic of EighteenthCentury Naval Architecture. New York: Dover Publications, Inc., 2006.

Childs, Cromwell Caleb to Arron Lopez, 22 September 1772, agreement to fit an upper deck on the Sloop Industry, Box 52, Folder 4, Sheet 52-172, Arron Lopez Papers, the Newport Historical Society Library, Newport Historical Society. Newport, Rhode Island.

Childs, Jeremiah Jr., Account Book, 1790-1815, the Rhode Island Historic Society Library and Archives, the Rhode Island Historic Society, Providence, Rhode Island.

Childs, Sylvester, Arron Lopez and Wright, 3 November 1772, Articles of Agreement, Box 52, Folder 4, Sheet 52-147, Arron Lopez Papers, the Newport Historical Society Library, Newport Historical Society, Newport, Rhode Island. City Gazette and Daily Advertiser, Oct. 26, 1791.at the Boston Public Library, Micro film. 
Christopher, Emma. Slave Ship Sailors and Their Captive Cargo. Cambridge; Cambridge University Press, 2006.

Cembrola, Bob. "The Whydah is for Real; An Archaeological Assessment." Seafarers, Journal of Maritime Heritage 1 (1987). Accessed March 2013. http://atochagold.com/TheWhydah.htm

Clarke, Capt. Peleg, regarding the purchase of 96 slaves, 3 Oct. 1772, Peleg Clarke Letters 1770-1784, the Newport Historical Society Library, Newport Historical Society, Newport, Rhode Island.

Clarke, Capt. from Fletcher, Estimate of Provisions for Guinea Voyage, 24 Feb.1772, Peleg Clarke Letters 1770-1784, the Newport Historical Society Library, Newport Historical Society, Newport, Rhode Island.

Clarke from Fletcher; intention to make another voyage to Africa, Dec 29, 1774, Peleg Clarke Letters 1770-1784, the Newport Historical Society Library, Newport Historical Society, Newport, Rhode Island.

Clarke, Peleg from John Fletcher, letter to trying to find a ship for the Guinea Voyage, 9 June 1771, Peleg Clarke Letters 1770-1784, the Newport Historical Society Library, Newport Historical Society, Newport, Rhode Island.

Clarke, Captain Peleg \& John Fletcher, memoir of agreement for sale of a New Brig, 6 February 1772, Box 52, Folder 4, Sheet 52-187, Arron Lopez Papers, the Newport Historical Society Library, Newport Historical Society, Newport, Rhode Island.

Clarke, Capt.Peleg from John Fletcher, purchasing a vessel for the Guinea Voyage, 
16 Oct. 1771, Peleg Clarke Letters 1770-1784, the Newport Historical Society Library, Newport Historical Society, Newport, Rhode Island.

Clark from Fletcher, regarding the Brig Thames, July 30, 1774, Peleg Clarke Letter Book 1774- 1782, The Newport Historical Society Library, Newport Historical Society, Newport, Rhode Island.

Clarke from Fletcher, regarding cargo on the brig Thames. Oct. $19^{\text {th }} 1775$, Peleg Clarke Letters 1770-1784, the Newport Historical Society Library, Newport Historical Society, Newport, Rhode Island.

Clarke from Fletcher, regarding the profits of the vessel, 24 Nov.1772, Peleg Clarke Letters 1770-1784, the Newport Historical Society Library, Newport Historical Society, Newport, Rhode Island.

Clarke, Capt Peleg from Ralph Inmans, assistance in securing a ship, 19 Jan 1772, Peleg Clarke Letters 1770-1784, the Newport Historical Society Library, Newport Historical Society, Newport, Rhode Island.

Clarke, Capt. Peleg from Ralph Inman, regarding the purchase of a vessel by a competitor, 11 May 1772, Peleg Clarke Letters 1770-1784, The Newport Historical Society Library, Newport Historical Society, Newport, Rhode Island.

Clifford, Barry. Expedition Whydah: The Story of the World's First Excavation of a Pirate Treasure ship and the man who found her. New York, NY; Harper Collins, 1999.

Cohn, R. and Jenson, R. "The Determinants of Slave mortality Rates in the Middle Passage.” Explorations in Economic History 19 (1982): 269-282. 
Committee of the Religious Society of Friends in London. Case of the Vigilante, $a$ Ship Employed in the Slave Trade; with Some Reflections on that Traffic. London: Harvey, Darton \& Company, 1823.

Cook, Greg. "The Maritime Archaeology of West Africa in the Atlantic World: Investigations at Elmina, Ghana.” (Dissertation, Syracuse University, 2012.)

Cost and outset of the sloop prudent, 1739, Box 126 Folder 19, The Newport Historical Society Library, Newport Historical Society, Newport, Rhode Island.

Coughtry, Jay. The Notorious Triangle; Rhode Island and the African Slave Trade 1700-1807. Philadelphia; Temple Univ. Press, 1981.

Craig, R. and R. Jarvis. Liverpool Registry of Merchant Ship. Manchester, Manchester University Press, 1967.

Decks of a Slaving Vessel, 1823-24. 1848. Newspaper print. The Illustrated London News 26 April 1848, Vol 13: 123.

Decorse, Christopher. The Archaeology of Elmina. New York, Elliot Werner Publications, 2001.

Donnan, Elizabeth. Documents Illustrative of the History of the Slave Trade to America: Volume I, 1400-1700. Buffalo NY; William S. Hein \& Co. Inc., 2002. Accessed November 15, 2014.

http://www.inmotionaame.org/texts/viewer. $\underline{\mathrm{cfm} ? \mathrm{id}=1 \_002 T \& p a g e=f 1 \& b h c p=1}$ Documents Illustrative of the History of the Slave Trade to America: Volume II, The Eighteenth Century. Buffalo NY; William S. Hein \& Co., Inc., 2002. 
Accessed November 15, 2014. http://www.inmotionaame.org/texts/viewer. $\underline{\mathrm{cfm}}$ ?id=1_017T\&page $=\mathrm{f} 1 \& \mathrm{bhcp}=1$

Documents Illustrative of the History of the Slave Trade to America: Volume III, New England and the Middle Colonies. Buffalo NY; William S. Hein \& Co. Inc., 2002. Accessed November 15, 2014. http://www. inmotionaame. org/texts/viewer. cfm?id=1_028T\&page=front 1

Documents Illustrative of the History of the Slave Trade to America: Volume IV, The Border Colonies and the Southern Colonies. Buffalo NY; William S. Hein \& Co. , Inc. , 2002. Accessed November 15, 2014. http://www. inmotionaame. org/texts/viewer. $\mathrm{cfm}$ ?id=1_026T\&page=f1

Dolin, Eric Jay. When America First Met China: An Exotic History of Tea, Drugs, and Money in the Age of Sail. New York; Liveright Publishing Corporation, 2013.

Drake, Richard. Scene in the Hold of the 'Blood-Stained Gloria'. 1860. Print, In “Revelations of A Slave Smuggler, New York, 1860: 28.

Duane, William. The Mariners Dictionary or American Seaman's Vocabulary of Technical terms And Sea phrases, used in the Construction, equipment, Management, and Military Operations of ships and vessels of all descriptions. Washington City, 1805.

Einzig, Paul. Primitive Money in its ethnological, historical and economic aspects. London; Eyre \& Spottiswoode, 1949.

Elder, Melinda. Slave Trade and the Economic Development of $18^{\text {th }}$-century Lancaster. Edinburgh University Press, 1992.

Eltis, David. Europeans and the Rise and fall of African Slavery. Oxford: Oxford 
University Press, 2001.

"The African Side of the Trade." A Brief Overview of the Trans-Atlantic Slave trade. (Emory University, 2007)

http://www.slavevoyages.org/tast/assessment/essays-intro-06.faces

"The Middle Passage." A Brief Overview of the Trans-Atlantic Slave trade.

(Emory University, 2007)

http://www.slavevoyages.org/tast/assessment/essays-intro-06.faces

"Early Slaving Voyages." A Brief Overview of the Trans-Atlantic Slave Trade.

Emory Unersity, 2007. http://www.slavevoyages.org/tast/assessment/essaysintro-02.faces

"The Enslavement of Africans." A Brief Overview of the Trans-Atlantic Slave Trade. Emory Unersity, 2007.

http://www.slavevoyages.org/tast/assessment/essays-intro-02.faces

Emmer, Pieter. The Dutch Trans-Atlantic Slave Trade, 1500-1850. New York:

Berghahn Books, 2006.

Entecost, Ernest H. Slave Ships and Slaving. Cambridge: Cornell Maritime Press, 1968.

Estep, H. Cole. How Wooden Ships are built: a Practical Treatise on Modern American Wooden Ship Construction, with a Supplement on Laying off Wooden Vessels. Cleveland: Peuton, 1918.

Equiano, Olaudah. The Interesting Narrative of the Life of Olaudah Equiano, or Gustavus Vass, The African. New York: Penguin Books, 2003.

Falconer, William. A Universal Dictionary of the Marine. London: T. Cadell, 1780. 
Fletcher from Capt. Clarke, regarding the number of slaves purchased, talks of the schooner Nancy, March 17, 1773, Peleg Clarke Letters 1770-1784, the Newport Historical Society Library, Newport Historical Society, Newport, Rhode Island.

Fletcher regarding insurance and the brig Thames Oct. $4^{\text {th, }}$ 1778, Peleg Clarke Letters 1770-1784, the Newport Historical Society Library, Newport Historical Society, Newport, Rhode Island.

Foote, Andrew H. American Naval Ship Encountering American Slave Ship, June 6, 1850. 1854. Print. In "Africa and the American Flag” New York, (1854), 286. (Copy in special collections, University of Virginia Library). http://hitchcock.itc.virginia.edu/Slavery/details.php?categorynum=5\&theRecor d=1\&recordCount=71, Accessed Nov. 152013.

Fox, William. Revolt aboard Slave Ship, 1787. 1851, Print. In "A Brief History of the Wesleyan Missions on the West Coast of Africa" London (1851), 116. http://hitchcock.itc.virginia.edu/Slavery/details.php?categorynum=5\&category $\underline{\text { Name }=\& \text { theRecord }=6 \& \text { recordCount }=71}$, Accessed Nov. 15, 2013.

Freeboy, Capt. John, outfitting of a ship, Box 126 Folder 19, The Newport Historical Society Library, Newport Historical Society, Newport, Rhode Island.

Garland, Charles and Herbert S. Klein. "The Allotment of Space for Slaves aboard Eighteenth-Century British Slave Ships.” The William and Mary Quarterly 42 (1985), 238-248.

Giddo, Frank. “Adelaide.” Others: Frank Giddo Underwater Archaeologist. Accessed Feb. 2013, http://www.underwaterdiscovery.org/projects/others/adelaide.html 
Gillow, John. African Textiles: Color and Creativity Across a Continent. Thames \& Hudson, 2009.

Gorell, F. "NOAA Supported Mission of Discovers Historic Shipwrecks off Turks and Caisco Islands." NOAA Ocean Explorer: The Search for the Trouvadore 2008, accessed Dec $12^{\text {th }} 2014$ http://oceanexplorer.noaa.gov/explorations/06trouvadore/welcome. html

Green, Jeremy N. The Loss of the Verenigde Oo 'stindische Compagnie retourschip Batavia, Western Australia 1629 an Excavation Report and Catalogue of Artifacts. BAR International Series 489. Oxford, British Archaeological Reports, 1989.

Grehan, Amedee. Africans Forced to Dance on Deck of Slave Ship. 1837. Print. In La France Maritime 3 (1837), 179.

http://hitchcock.itc.virginia.edu/Slavery/details.php?categorynum=5\&category

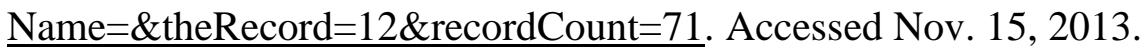

Halbwachs, Maurice and Lewis A. Coser. On Collective Memory. Chicago: University of Chicago Press, 1992.

Harms, Robert. The Diligent: A Voyage through the World of the Slave Trade. New York; Basic Books, 2002.

Henderson, Graeme. "The Wreck of the Ex-Slaver 'James Matthews'.” International Journal of Historical Archaeology 12 (2008): 39-52.

Herbert, Eugenia. Red Gold of Africa: Copper in Precolonial History and Culture. Madison: University of Wisconsin Press, 1984.

Herry, Nolwenn. "Report on the Finds from the Saint-Quau-Portrieux Wreck, France." 
The International Journal of Nautical Archaeology 33(2004): 96-105.

Hogendorn, J.S, and H.A. Gemery. "The 'Hidden Half' of the Anglo-African Trade in the Eighteenth Century: The Significance of Marion Johnson's Statistical Research" in West African Economic and Social History: Studies in Memory of Marion Johnson. Madison: University of Wisconsin African Studies Program, 1990.

Hogendron, Jan \& Marion Johnson. The Shell money of the Slave Trade. Cambridge: Cambridge University Press, 2003.

Hogerzeil, Simon and David Richardson. "Slave Purchasing Strategies and Shipboard Mortality: Day-to-Day Evidence from the Dutch African Trade, 1751-1797.” The Journal of Economic History 67 (2007): 160-190.

Hopkins, A. G. An Economic History of West Africa. London, UK: Longman, 1973.

Howard, Johnson, “The Liberated Africans, 1811-1860" in The Bahamas in Slavery and Freedom. Kingston, Jamaica: Ian Randle Publishers, 1991.

Howe, Henry. Stowing the Cargo of a Slaver at Night, 1856, Engraving, in Life and Death on the Ocean: A Collection of Extraordinary Adventure in the Form of Personal Narratives. Cincinnati, 1856.

Huggins, William John, The Capture of the Slaver Formidable by HMS Buzzard, 17 December 1834, Oil on canvas on panel, $380 \mathrm{~mm}$ x $545 \mathrm{~mm}$, National Maritime Museum, Greenwich, London, Macpherson Collection, http://collections.rmg.co.uk/collections/objects/12117.html

Hume, Ivor Noel. A Guide to Artifacts of Colonial America. Philadelphia: University 
of Pennsylvania Press, 1969.

The Illustrated London News. Section of the Slaver "Abbot Devereux”, 1857, Line Drawing, in The illustrated London News 31: 1857.

Capture of a Large Slave-Ship by the HMS Pluto, 1860, print, in the Illustrated London News 36: April 28, 1860.

Inaman, Ralph from Peleg Clarke, progress of securing a Guineman, 29 April 1772, Peleg Clarke Letters 1770-1784, the Newport Historical Society Library, Newport Historical Society, Newport, Rhode Island.

Insurrection aboard the Thames and insurance claims, Jan 7, 1777, Peleg Clarke Letters 1770-1784, the Newport Historical Society Library, Newport Historical Society, Newport, Rhode Island

Inikori, J. "The Import of Firearms into West Africa 1750-1897: A Quantitative Analysis." Journal of African History, 18 (1977): 339-368.

Jackson, William. A Liverpool Slave Ship. 1780. Oil on Canvas. $102 \mathrm{~cm} \times 127 \mathrm{~cm}$, Merseyside Maritime Museum, Liverpool.

Johansson, Sven-Olof. Nigerian Currencies: Manillas, Cowries and Others. Skolgatan, Norrkoping: Alfa-Tryck, 1967.

Johnson, Howard. The Bahamas in Slavery and Freedom. Ian Randle Publishers, Kingston Jamaica, 1991.

Jordan, Winthrop D. White over Black: American Attitudes toward the Negro 15501812. The Chapel Hill: University of North Carolina Press, 1968.

Karklins, K. “Seventeenth Century Dutch Beads.” Historical Archaeology, 8 (1974); 64-82. 
Glass Beads. Ottawa: Parks Canada Studies in Archaeology, 1985.

"Beads from the Mid-18th-century Manilla Wreck, Bermuda" The

International Journal of Nautical Archaeology 20.1(1991): 33-42.

Kelleher, C. 'The Dunworley Bay Shipwreck: Seventeenth-Century Evidence for Piracy and Slavery in Ireland?' ACUA Underwater Archaeology Proceedings 2010. London; ACUA (2010):138-145.

Klein, H. "North American Competition and the Characteristics of the African Slave Trade to Cuba, 1790 to 1794.” The William and Mary Quarterly, 28:1 (1971) 86-102.

The Atlantic Slave Trade. Cambridge: Cambridge University Press, 2010.

Lawernce, A.W. Trade Castles and Forts of West Africa. London: Jonathan Cape, 1963.

Leiden Museum De Lakenhal. “Seven Centuries of Leiden Cloth.” Accessed February 2015. http://lakenhal.nl/en/story/leiden-cloth

Liverpool Slave Trade Collection, The log of the Mampockata, DX/2277, Maritime Archives and Library, Merseyside Maritime Museum, Liverpool, England.

Lloyd, Henry to Arron Lopez, for information about how to outfit a ship, July 1765 , Box 177, The Newport Historical Society Library, Newport Historical Society, Newport, Rhode Island.

Longmore, J. 'Cemented by Blood of a Negro?' The impact of the Slave trade on Eighteenth Century Liverpool”, in) Liverpool and Transatlantic Slavery, edited by Richardson, D. Tibbles, A. and Schwarz, S., 227-251. Liverpool: Liverpool University Press, 2007. 
Lopez to Barney and Hill, 5 August 1761, For the Building of two single deck Sloops, Box 52, Folder 4, Sheet 52-139, Arron Lopez Papers, the Newport Historical Society Library, Newport Historical Society. Newport, Rhode Island.

Lopez, Arron, Benjamin Bowers \&Benjamin Allan, agreement, Box 52, Folder 4, Sheet 52-156, Arron Lopez Papers, the Newport Historical Society Library, Newport Historical Society, Newport, Rhode Island.

Lopez, Bowens and Allen, July 1766, Business Correspondents, Box 52, Folder 4, Sheet 52-157, Arron Lopez Papers, The Newport Historical Society Library, Newport Historical Society, and Newport, Rhode Island.

Lopez, Arron from Caleb Surner, about building boats for Lopez, Feb 6, 1775, Box 172 Folder 2, The Newport Historical Society Library, Newport Historical Society, Newport, Rhode Island.

Lopez, Arron to George Brown, 29 December 1769, Letter, Box 52, Folder 4, Sheet 52-169, Arron Lopez Papers, the Newport Historical Society Library, Newport Historical Society. Newport, Rhode Island.

Lopez, Arron to Richard Thomas, 7 September 1763, Letter regarding the building of The Sally, Box 52, Folder 4, Sheet 52-141, Arron Lopez Papers, the Newport Historical Society Library, Newport Historical Society, Newport, Rhode Island.

Lorenz, Felix and Alex Hubert. A Guide to World Cowries. Wiesbaden: Verlag Christa Hemmen, 1993.

Luckenbach, Al and C. Jane Cox. "17th Century Lead Cloth Seals from Anne Arundel County, Maryland." Maryland Archeology 39 (2000): 17-26. 
Lyhster to Childs, Articles of agreement for a ship, 28 December 1774, Box 52, Folder 4, Sheet 52-181, Arron Lopez Papers, the Newport Historical Society Library, Newport Historical Society. Newport, Rhode Island.

Malcom, Corey. "The Re-examination of the Hull of the Henrietta Marie." Mel Fisher Maritime Heritage Society, Key West, 2001.

"A Collection of Artifacts Recovered from the Shipwreck Henrietta Marie, 2002." Mel Fisher Maritime Heritage Society, Key West, 2002.

Malcom, Neverme from Capt. Clarke; regarding outfitting of a vessel, April 21, 1775, Peleg Clarke Letters 1770-1784, the Newport Historical Society Library, Newport Historical Society, Newport, Rhode Island.

Malcom P.R. Light. "Global Warming and the Gulf Stream- Our Atmosphere Pollution Roadway to Subsea Arctic Methane-Induced Climatic Hell”, Arctic News January $5^{\text {th }} 2014$. http://arctic-news.blogsic pot.com/2014/01/globalwarming-and-the-gulf-stream. Html

Maritime History of Northern Britain. "The War at Sea: On September 2, 1795, the sinking of the former slaver 'national assembly' in the north of the island of Er.” Accessed Feb 2013.

McMillan, Lauren. "Put This in Your Pipe and Smoke it: An evaluation of Tobacco Pipe Stem Dating Methods.” Master's thesis, East Carolina University, 2010.

Metz, Helen Chapin, ed. "Slave Trade," in Nigeria: A Country Study. Washington: GPO for the Library of Congress, 1991. Accessed March 2013, http://countrystudies.us/nigeria/7.htm.

Meynell, Lt. Francis. Slave deck of the Albaroz, Prize to the Albatross 1845, 1845, 
Pencil and Water color, at National Maritime Museum, London.

Moore, David Receipt book, 1761-1775, Box 126 Folder 19, The Newport Historical Society Library, Newport Historical Society, Newport, Rhode Island.

Moore, David. "Site Report: Historical and Archaeological Investigation of the Shipwreck Henrietta Marie.” Mel Fisher Maritime Heritage Society, 1997.

Moore, David and Corey Malcom. "Seventeenth-Century Vehicle of the middle Passage: Archaeological and Historical Investigation on the "Henrietta Marie" Ship wreck site.” International Journal of Historical Archaeology 12 (2008): 20-38.

Mouser, B. A Slaving Voyage to Africa and America. Bloomington: Indiana University Press, 2002.

National Maritime Museum. The anchorage off the Town of Bonny River sixteen miles from the Entrance, water color with graphite, 200mm x 370mm, National Maritime Museum, Greenwich London, http://collections.rmg.co.uk/collections/objects/106080.html

Nicholls, Joseph. Captain Teach commonly call'd Blackbeard. 1736, engraving. 28.3 cm x 19.4, in Captain Charles Johnson. A General History of the lives and adventures of the most famous highwaymen, murders, street-robbers, and captains. (Horace's head: London, 1736), 202. Housed in the John Carter Brown Library at Brown University.

North Museum Service Center. Lead bale seal from Salem Maritime National Historic site, 2012, photograph, Salem Maritime National Historic Site Collection , Salem Ma. https://nmscarcheologylab.wordpress.com/page/4/ 
Oursel, Pretexat. Top Deck of French Slave Ship, $19^{\text {th }}$ Century. Color lithograph. Musee d'Historie de la Ville et du Pasy Malouin. Saint malo, France. http://hitchcock.itc.virginia.edu/Slavery/details.php?categorynum=5\&category $\underline{\text { Name }=\& \text { theRecord=7\&recordCount=78. }}$. Accessed Nov. 15, 2013. Outfitting of the sloop Queen of Hungary, 1744, Box 126 Folder 19, The Newport Historical Society Library, Newport Historical Society, Newport, Rhode Island.

Owners of the brigantine Hannah bills due, 1768, Box 177, The Newport Historical Society Library, Newport Historical Society, Newport, Rhode Island.

Pinfold, John. The Slave Trade Debate: Contemporary Writings for and Against. Oxford, England: The Bodleian Library, 2007.

Polock, Hay to Cromwell Child, Box 52, Folder 5, Sheet 52-189, Arron Lopez Papers, The Newport Historical Society Library, Newport Historical Society, Newport, Rhode Island.

Pond, S. "The Spanish Dollar: The World's Most Famous Silver Coin." Bulletin of the Business Historical Society 15 (1941):12-16.

Postma, Johannes. The Dutch in the Atlantic Slave Trade, 1600-1815. Cambridge: Cambridge University Press, 1990.

Rawley, James and Stephen D. Benrendt. The Transatlantic Slave Trade: A History. University of Nebraska Press, 2005.

Rawson, K.J. and E.C. Tupper. Basic Ship Theory Vol.1 \& Vol.2. New York, NY: Longman Inc., 1976. 
Rediker, Marcus. The Slave Ship; A Human History. New York: Penguin, 2007.

Reid, G. Marine Salvage. New York: Sheridan House Inc., 1996.

Reiss, O. Blacks in Colonial America. North Carolina: McFarland and Company, 1997.

Richardson, David. "Liverpool and the English Slave Trade" in Transatlantic Slavery: Against Human Dignity. Liverpool: National Museums. (2005): 67-72.

Rodriguez, Junius P. “Ships,” The Historical Encyclopedia of World Slavery Volume1 -7. Santa Barbra, California; ABC-CLIO, 1997. "Shipbuilding," The Historical Encyclopedia of World Slavery Volume 1-7. Santa Barbra, Ca: ABC-CLIO, 1997.

Rugendas, Johann Moritz. Enslaved Africans in Hold of Slave Ship. 1835. Print. In “Voyage Pittoresue dans le Bresil” Paris, 1835. http://hitchcock.itc.virginia.edu/slavery/search.html. Accessed Nov. 15, 2013.

Sadler, Nigel. "The Trouvadore Project: The Legacy of a Sunken Slave Ship." The African Diaspora Archaeology Network. 1:27 (2007): 1.

The 'Trouvadore' Project: the Search for a Slave Ship and its Cultural Importance. In the International Journal of Historical Archaeology. 12:1 (2003):53-70.

Trouvadore -- Legacy of a Slave Ship, Discover Turks and Caicos, (2007):2628.

The Sale of the Peggy, 1773, Box 106 Folder 19. The Newport Historical Society Library, Newport Historical Society, Newport, Rhode Island.

Schmidt, Peter and Jonathan Walz. "Re-Representing African pasts through Historical 
Archaeology.” American Antiquity 72 (2007): 53-70.

Schwarz, Suzanne. Slave Captain: The Career of James Irving in the Liverpool Slave Trade. Liverpool University Press, 2008.

Slenes, Robert W., African Abrahmas, Lucretias and Men of Sorrows, Allegory and Allusion in the Brazilian Anti-slavery Lithographs (1827-1835) of Johann Moritz Rugendas, Slavery \& Abolition, 23:2002.

Smith, Clifford Earle. “The Manilla Wreck: Bermuda's role in the Atlantic slaveSmuggling Trade.” PhD diss., University of Kentucky, 2003.

Smith, Matt. "The Artefact Biography of a Slave Shipwreck; the Enterprise." Master's Thesis, Barton College, 2010.

Smith, Michael. "Locating Slave Shipwrecks, Innovative approaches to digital and archival resources." Presentation Newcastle University, School of History, Classics and Archaeology.

Snyder, R. "A Victim of Circumstance: The Timber Bill of 1772 and the East India Company.” Past Imperfect 1 (2008):27-57.

Sopeff, David, Enoch Lyson and Arron Lopez, 1764, Articles of Agreement to deliver A ship built by Abiel Chase. Box 52, Folder 4, Sheet 52-147, Arron Lopez Papers, the Newport Historical Society Library, Newport Historical Society, Newport, Rhode Island.

St. Jame's Chronicle, August 23, 1787, Issue 4142. .

Steffy, Richard J. Wooden Ship Building \& the Interpretation of Shipwrecks. College Station; Texas A\&M University Press. 1994.

Suarez, Michael. "The Print that Changed the World: The Description of the Slave- 
Ship Brookes.” Lecture, Brown University, Providence RI, November 12, 2013.

Svalesen, Leif. The Slave Ship Fredensborg. Indianapolis: Indian Univ. Press, 2000. “The Slave Ship Fredensborg; History, Shipwreck, and Find." History of Africa 22 (1995): 455-458.

Swanson, Gail. "The Wrecking of the Laden Spanish Slave Ship Guerrero off the Florida Keys, In 1827.” African Diaspora Archaeology Newsletter 13:3 (2010) $1-6$.

The Thames taken by a privateer, Sept. 25, 1778, Peleg Clarke Letters 1770-1784, The Newport Historical Society Library, Newport Historical Society, Newport, Rhode Island.

Thornton ,John. Africa and Africans in the Making of the Atlantic World, 1400-1680. Cambridge: Cambridge University Press, 1992.

Turks and Caicos National Museum. "Slave Ship Archaeology, Sorting Through the Clues.” Accessed Dec. 2013. http://slaveshiptrouvadore.org/search-fortrouvadore/slaveship-archaeology/

Voyages Database. Voyages: The Trans-Atlantic Slave trade Database. Accessed Jan 2014, http://www.slavevoyages.org

Villeneuve, René Claude Geoffroy de. Ile St. Louis near the mouth of the Senegal River, 1814, "Vue de l'île St. Louis du Sénégal prise de côte de la mer." René Claude Geoffroy de Villeneuve, Illustrations de L'Afrique ou histoire, moeurs, usages et coutumes des Africains. Nepveu. Paris, 1814. Bibliothèque Nationale de France. (ark:/12148/cb38495427c) 
Wadstrom, Carl b. Revolt Aboard Salve Ship, 1787. In "An Essay on Colonization, particularly applied to the Western Coast of Africa...in two parts" London 1794.

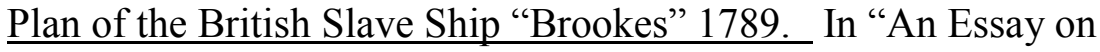

Colonization particularly applied to the Western Coast of Africa...in Two Parts" London 1794.

Walsh, Robert LL. D. Notices of Brazil in 1828 and 1829. London: British Library, Historical Prints Editions, 2011.

Ward, W. E. F. The Royal Navy and the Slavers. The Suppression of the Atlantic Slave Trade. New York, NY; Pantheon Books, 1968.

Warde, Paul. "Fear of wood Shortage and the reality of woodland Europe, 14501850.”Historical Workshop Journal, 62 (2006): 28-57.

Webster, Jane. "Historical Archaeology and the Slave ship.” International Journal of Historical Archaeology 12 (2008): 1-5.

"Slave Ships and Maritime Archaeology: An Overview” International Journal of Historic Archaeology, 12 (2008): 6-19.

Weisbord, Robert. “The Case of the Slave-ship Zong: 1783”. History Today, 19 (1969):8.

Wells, Tom H. The Slave Ship Wanderer. Athens, GA: University of Georgia Press, 2009.

Western Australian Museum. “James Matthews.” Accessed Jan. 2014. http://museum.wa.gov.au/research/research-areas/maritimearchaeology/treasures-from-the-deep/james-matthews 
Wethmerland from Clarke, regarding the snow Thames, 13 Jan 1774, Peleg Clarke Letters 1770-1784, the Newport Historical Society Library, Newport Historical Society, Newport, Rhode Island.

Wilde-Ramsing, Mark and Rick Lawrence. "In Search of Blackbeard: Historical and Archaeological Research at Shipwreck site 003BUI”. Accessed March 2014. http://www.qaronline.org/History/TheShipsJourney.aspx

Wilde-Ramsing, Mark. "Historical background for the Queen Anne’s Revenge Shipwreck Site" Queen Anne 's Revenge Shipwreck Project; Research report and bulletin Series QAR-R-09-02. Aug 2009. (Accessed Feb 2013). http://wayback.archive-it.org/org67/20120515002435/http://www.qaronline.org/techSeries/QAR-R-09-02.pdf

Williams, Eric. "Economics, Not Racism as the Root of Slavery." The Atlantic Slave Trade. Lexington, Mass. DC heath \& Co., 1994.

Wilson, Kax. A History of Textiles. Boulder, Co.: Westview Press, 1979.

Smith, William. A voyage to Guinea. 1774. Lithograph. In plate 61Thomas Astley's, A New General Collection of Voyages and Travels. London, 1745-1747.

Wilson, Kax. A History of Textiles. Boulder, Colo.: Westview Press, 1979.

Young, Arthur and James Brisbane. Nautical Dictionary. London: Longman, Green and Roberts, 1863.

Zahedieh, Nuala. The Capital and the Colonies: London and the Atlantic Economy, 1660-1700. Cambridge: Cambridge University Press, 2010.

The Statutes at Large from the Twenty-fifth Year of the Reign of King George the Third. London, Strahan \& Woodfall. (1785): 512. Accessed Dec. 15, 2014 
https://play.google.com/books/reader?id=eqZFAAAAcAAJ\&printsec=frontco ver\&output=reader $\&$ hl $=$ en $\& p g=$ GBS.PP5 